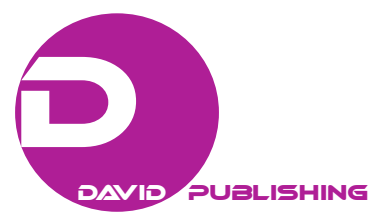

\title{
Edward Burne-Jones's The Planets: Musical Spheres and Visions of a Benevolent Cosmos*
}

\author{
Liana De Girolami Cheney \\ SIELAE, Universidad de Coruña, Coruña, Spain
}

\begin{abstract}
Edward Burne-Jones (1833-1898), a pre-Raphaelite painter, was fascinated with astronomy, as noted in his memorials and accounts. In 1879, he executed cartoon drawings for a cycle on nine planets for the artisans of the William Morris Firm, who would transform them into stained-glass panels. The commission was for the decoration of Woodlands, the Victorian mansion of Baron Angus Holden (1833-1912), a major of Bradford. Presently, seven of the cartoons-The Moon (Luna), Earth (Terra), Sol (Apollo), Venus, Jupiter, Saturn, and Evening Star-are in the Torre Abbey Museum in Torquay, UK, while the cartoon for Mars is part of the collection of drawings at the Birmingham Museum and Art Gallery, UK, and the cartoon for Morning Star is located at Lady Margaret Hall in Oxford, UK. In the creation of the Planets cycle, Burne-Jones was inspired by cultural events of the time such as British scientific astronomical discoveries and British and Italian humanistic sources in literature and visual arts portraying astronomy. This essay art historically and iconographically examines the nine planets as celestial and terrestrial formations and astral spheres of good omen. It is composed of three sections. The first section discusses the history of the artistic commission; the second analyzes the stylistic and iconographical aspects of the Planets cycle; and the third section explains some of Burne-Jones's cultural sources for the Planets cycle as manifestations of seasonal transformations, heavenly and terrestrial realms, musical spheres, and visions of a benevolent cosmos.
\end{abstract}

Keywords: British astronomy, Italian astrology, celestial cosmos, planets, musical spheres, seasons, Victorian homes, Edward Burne-Jones

\section{History of the Commission}

In 1879, Edward Burne-Jones (1833-1898) and William Morris (1834-1896) received a new commission

\footnotetext{
*Acknowledgements: I express my gratitude to Dr Joseph Harvey, Custodian, Torre Abbey Historic House and Galleries, for his email communications and generous assistance on Edward Burne-Jones's seven cartoons; Jane Palmer, Assistant Curator of the Torre Abbey Historic House and Galleries, for her assistance on the archival and photographic documentation; Reverend Dr. Allan Doig, Fellow and Chaplain, and his assisstants, Joshua Goldman and Alastair Person, at Lady Margaret Hall, Oxford, UK, for the photogragrah and information of the Stella Matutina cartoon; Victoria Osborne, Curator (Fine Art) and Curatorial Team Leader, Birmingham Museums Trust at the Birmingham Museum and Art Gallery, for her assistance on the Mars cartoon; and Gabreal Franklin, auctioneer of Franklin Collection, for his email communications and assistance on the history of the Burne-Jones's Planets in stained-glass panels. Two short studies on my interest about Edward Burne-Jones's planets and astronomy have been published: Liana De Girolami Cheney, "Edward Burne-Jones's The Planets: The Cartoon of Mars at the Birmingham Museum and Art Gallery," The Pre-Raphaelite Society 25 (Winter 2016), 15-26 (I thank Serena Trowbridge of Birmingham City University for her generous comments); and Liana De Girolami Cheney, "Edward Burne-Jones's The Planets: Luna, A Celestial Sphere," Culture and Cosmos: Journal for the History of Astrology and Cultural Astronomy 21 (Spring/Summer 2017).

Liana De Girolami Cheney, Ph.D., Visiting Researcher in Art History, SIELAE, Universidad de Coruña, Spain. http://atsah.wordpress.com.
} 
from Baron Angus Holden (1833-1912), a woolen manufacturer and mayor of Bradford. ${ }^{1}$ The project consisted of a glass decorative cycle about the planets for a large, 20-feet-high, semi-circular window in Holden's Music Room in his Victorian mansion, called Woodlands, outside of Bradford (see Figure 1).

An engraving of Woodlands shows the mansion in an irregular "L" shape, each of the two wings being about 130 foot long. In the center of the bottom stroke of the "L" was the main entrance, above which was a square battlemented tower used as an observatory. ${ }^{2}$

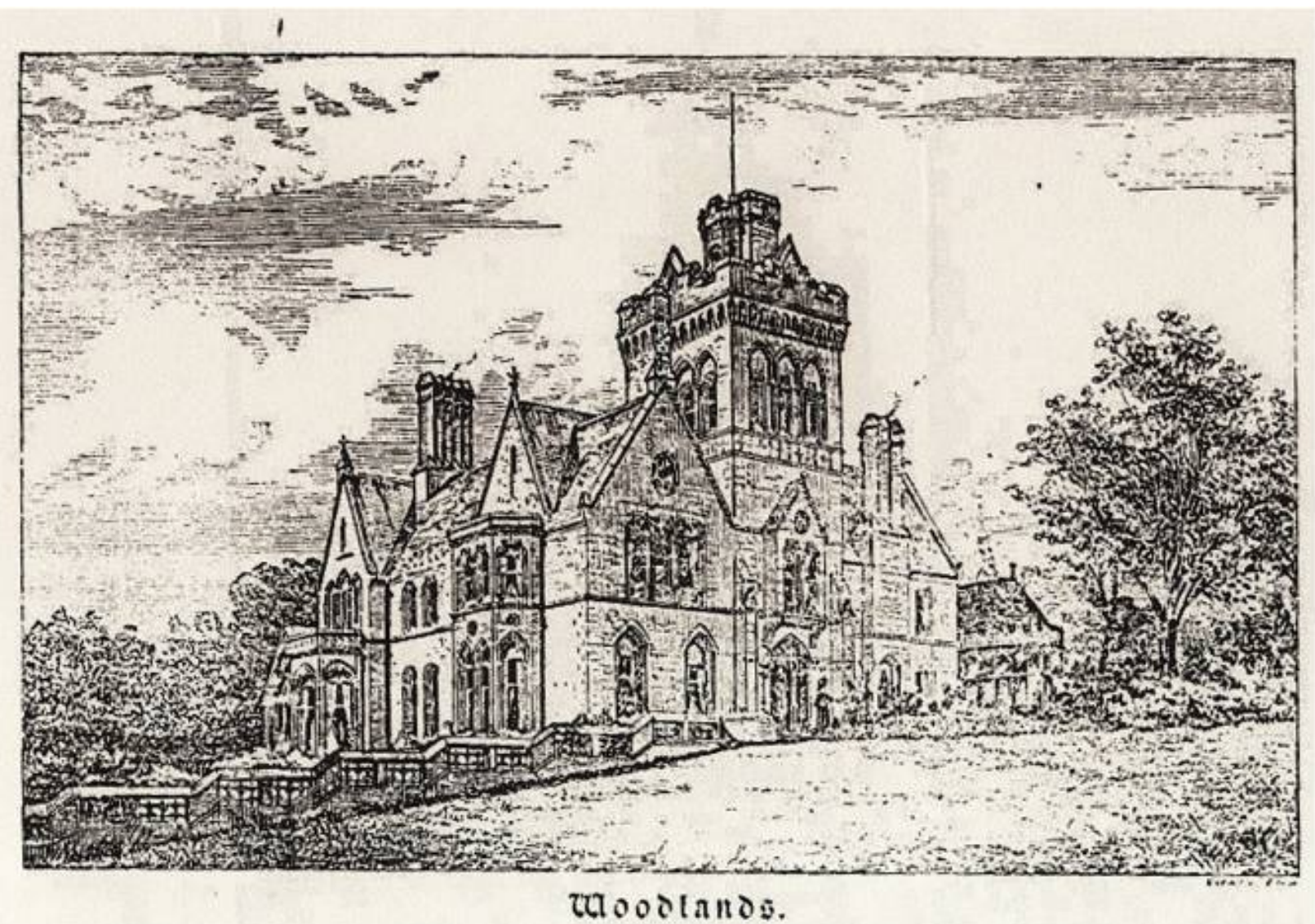

Figure 1. Woodlands of Bradford, UK, 1866, engraving.

According to L. Retallack, former Curator of the Torre Abbey Museum, Angus Holden purchased Woodlands to display his famous collection of paintings and works of art. ${ }^{3}$ In 1866, an architectural wing was added on the north end of the house as part of the Victorian Gothic mansion, and this area functioned as a

\footnotetext{
${ }^{1}$ Before the Holden commission, Edward Burne-Jones and William Morris were involved in earlier projects on this subject. In early 1858 the two men decorated with stained glass the church windows of All Saints at Selsley in Gloucestershire. The rose window illustrates God's creation from the Book of Genesis. One roundel represents the planets, the stars, the moon, and the sun. A few years later, in 1861-1865, Morris and Burne-Jones engaged in another astronomical project, using the signs of the zodiac in the decoration of the Green Dining Room at South Kensington Museum in London, now part of the Victoria and Albert Museum. See Penelope Fitzgerald, Edward Burne-Jones (London: Hamilton, 1975), 99. See also Archives at the Torrey Abbey Museum, Letter of 11 June 1992, between D. J. R. Green of Gloucester and L. Retallack, then Curator of the Torre Abbey Museum; and Michael Rhodes, Devon's Torre Abbey: Faith, Politics and Grand Designs (New York: The History Press, 2015).

2 See Archives at the Torrey Abbey Museum, Michael Rhodes's unpublished essay on "Earth by Sir Edward Coley Burne-Jones," dated 17 November 1997, 2, n. 8. Rhodes cited an excerpt of Edward Healey on "Woodlands of Bradford" in Bradford Illustrated Weekly (1885), 53-55.

3 Ibid.
} 
Music Room. The description of the Music Room according to Michael Rhodes' recount is intriguing:

The [area] was a large and lofty apartment, lighted partially from the roof and partially from the semi-circular window, which was near a large bay or apsidal window. This bay window was 20 feet high, and the lights were divided by stone transoms; the upper compartment being filled with nine stained glass figures the work of the celebrated artist Burne-Jones. The figures are a series of allegorical representations of the sun, moon, and planets, and are in the best style of the painter.

Stained-glass panels with the theme of the planets were a fitting topic for a music room, for the celestial spheres were traditionally associated with music of the spheres. ${ }^{5}$ Burne-Jones completed nine cartoons for the Morris Firm, which transformed them into stained-glass panels in $1879 .^{6}$

Twenty years later, the nine cartoons and stained-glass panels encountered a series of mishaps. In 1890, the Holden family left Woodlands and moved to Nun Appleton Hall, near York. Woodlands was demolished in 1899. It is uncertain whether Burne-Jones and Morris's windows were still in the house at the time or were transferred to the new mansion in Nun Appleton. Regrettably, Lord Holden died in 1912, and the family account of the property sale of 1917 makes no mention of the stained-glass windows or panes. Between 1919 and 1920, Sir Benjamin Dawson (1878-1966), First Baronet and Bradford textile manufacturer, purchased Nun Appleton Hall and lived there for more than forty years. Two articles on this mansion appeared in the Yorkshire Life (March 1955 and March 1960), but neither one mentioned Burne-Jones's glass panels. ${ }^{7}$ But the Yorkshire Life of March 1955 did note that when the Dawson family moved into Nun Appleton Hall they renovated the Victorian house "by demolishing the incongruous Gothic wing on the west side"; perhaps the glass-stained

\footnotetext{
${ }^{4}$ Ibid. Rhodes's essay continues describing Healey's account of the furnishing in the Music Room:
}

At the opposite end of the room is a fernery in a recess extending across the greater portion of the wall, and shot off from the room by a large sheet of plate glass. By this means is preserved to the occupants of the room at all seasons of the year the grateful and refreshing verdure of the delicate plants which appear to be springing naturally from the rock work. Both of the walls and ceiling of the room are of polished oak ornamented in graceful and fantastic designs. A special feature is the fireplace, also of carved oak, in the design and adornment of which great skill and taste has been shown. It is of enormous proportions, the finials with which the corners and center are crowned reaching nearly to the roof. The interior portion is of carved Caen stone, and is roomy enough to allow of seats in imitation of the old fashioned "ingle nook" being placed on each side.

\footnotetext{
The description continues commenting on the paintings and sculptures located in the room.

5 See Joscelyn Godwin, Harmony of the Spheres: A Sourcebook on the Pythagorean Tradition in Music (Rochester, VT: Inner Traditions International, 1990), 282, and 442-444; Jamie James, The Music of the Spheres: Music, Science and The Natural Order of the Universe (New York: Copernicus, 1993); and Marc Lachièze-Rey and Jean-Pierre Luminet, Figures du Ciel: de l'armonie des spheres à la conquête spatiale (Seuil: Bibliothèque nationale de France, 1988), 58-62.

6 According to the records of the Birmingham Museum and Art Gallery, the Morris Firm completed two separate sets of stained-glass panels for the Planets cycle: nine in 1879 for Woodlands; and a second set of ten in 1901 for W. E. Cooper of Hume Towers, Branksome Wood Road in Bournemouth (including Venus, Luna, Morning Star, Evening Star, Saturn, Mars, Earth, Sol, Jupiter, and Apollo). The location of these latter stained glass panels is presently unknown. These sites were demolished by war between 1940 and 1966. See A. C. Sewter, "Notes on Morris \& Co.'s Domestic Stained Glass," retrieved from www.morrissociety.org/JWMS/01.1-Winter1961/W61.Sewter.pdf; and http://bmag.onlinegalleries.com/metadot/index (access 15 January 2017). See also Malcolm Bell, Edward Burne-Jones: A Record and Review (London: George Bell \& Sons, 1892), 120; and A. C. Sewter, The Stained Glass of William Morris and his Circle (New Haven: Yale University Press, 1974-1975), 25,185 , and 208.

7 See Archives at the Torre Abbey Museum, correspondence between D. J. R. Green of Gloucester with Gordon Hand, Librarian of North Yorkshire County, and L. Retallack, then Curator of the Torre Abbey Museum. The letters are dated 23 June 1993, and 25 June 1993. See also Sewter, The Stained Glass of William Morris and his Circle, 208.

8 Archives at the Torre Abbey Museum, correspondence between D. J. R. Green of Gloucester with Gordon Hand, Librarian of North Yorkshire County, and L. Retallack, then Curator of the Torre Abbey Museum, Letter of 25 June 1993. There is a discrepancy in the literature regarding the location of this music room, whether it was located in the north or west side of the Victorian mansion.
} 
panels were located in this area. In any event, a large part of the Nun Appleton Hall mansion was partially demolished in 1920 and totally destroyed before 1935. So, since 1899, there is no clear trace of Burne-Jones and Morris's stained-glass panels. This essay will not examine the complicated history of the glass panels but will focus on the cartoon drawings. ${ }^{9}$

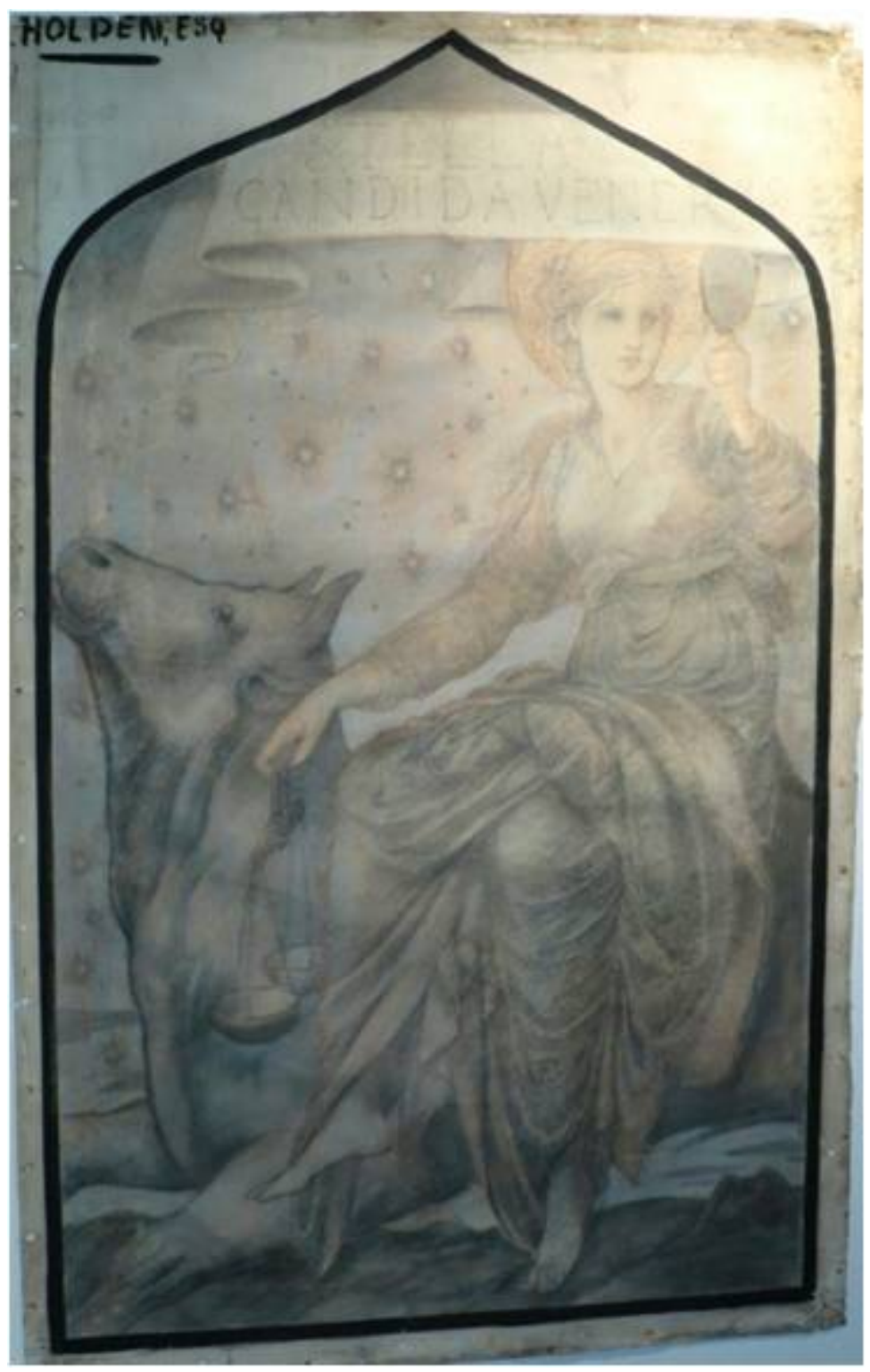

Figure 2. Edward Burne-Jones, Venus (Stella Candida Venere), 1879, cartoon.

\footnotetext{
9 A possible arrangement of the cartoons suggests this presentation at the Woodlands window: Luna, Earth (Terra), Sol (Apollo), Mars, Morning Star, Venus, Jupiter, Saturn, and Evening Star. Auctioneer Gabreal Franklin proposes an alternate format for the surviving stained-glass panels: Morning Star, Evening Star, Jupiter, Sol (Apollo), Mars, Venus, and Luna. Unfortunately, Saturn and Earth (Terra) are missing. See from http://www.allplanet.com/glass/BJ5.htm. See the Coda in this essay for a brief summary on the history of the glass panels.
} 

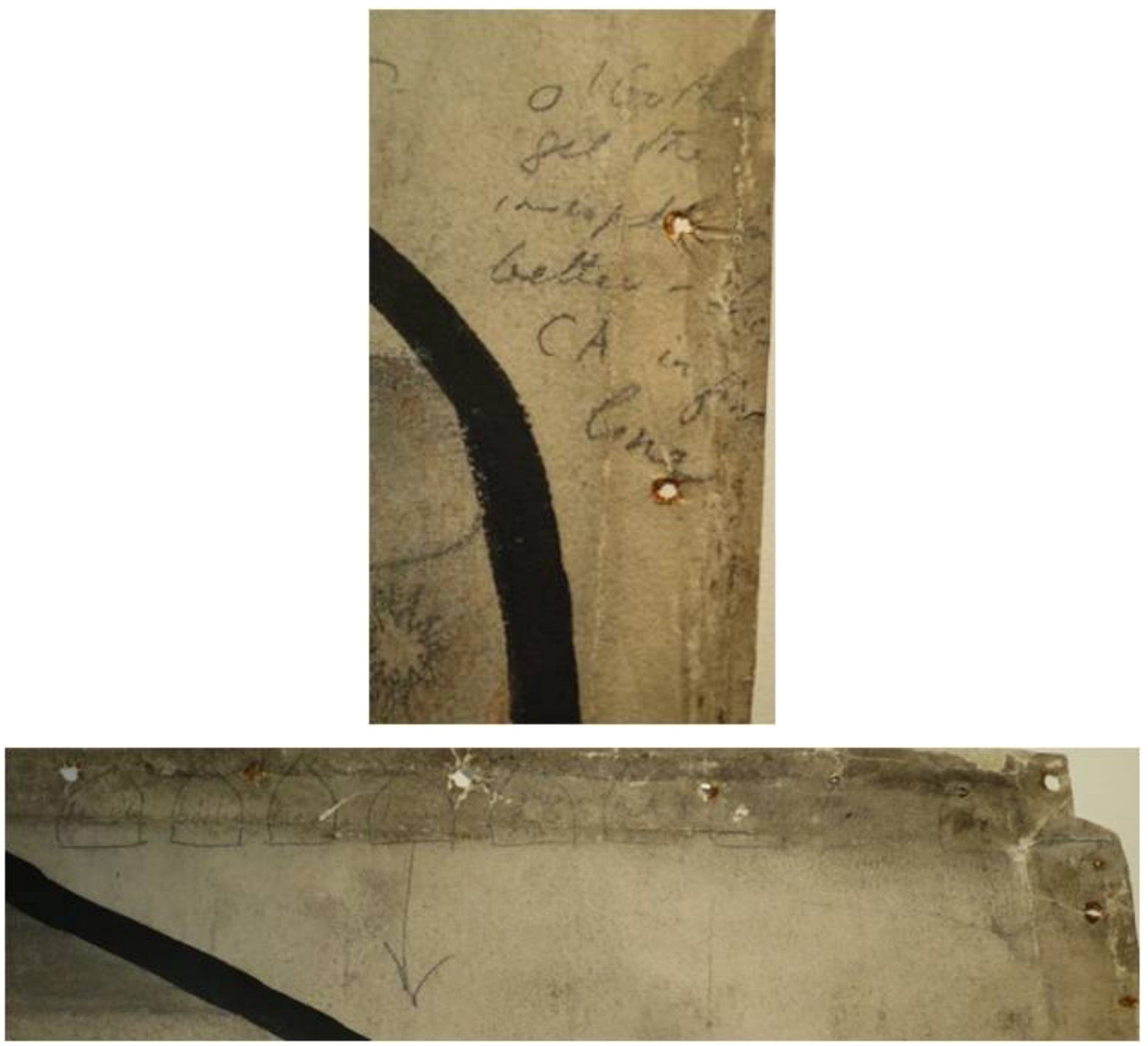

Figure $2 b$ and 2c. Edward Burne-Jones, Venus (Stella Candida Venere), det., 1879, cartoon. 


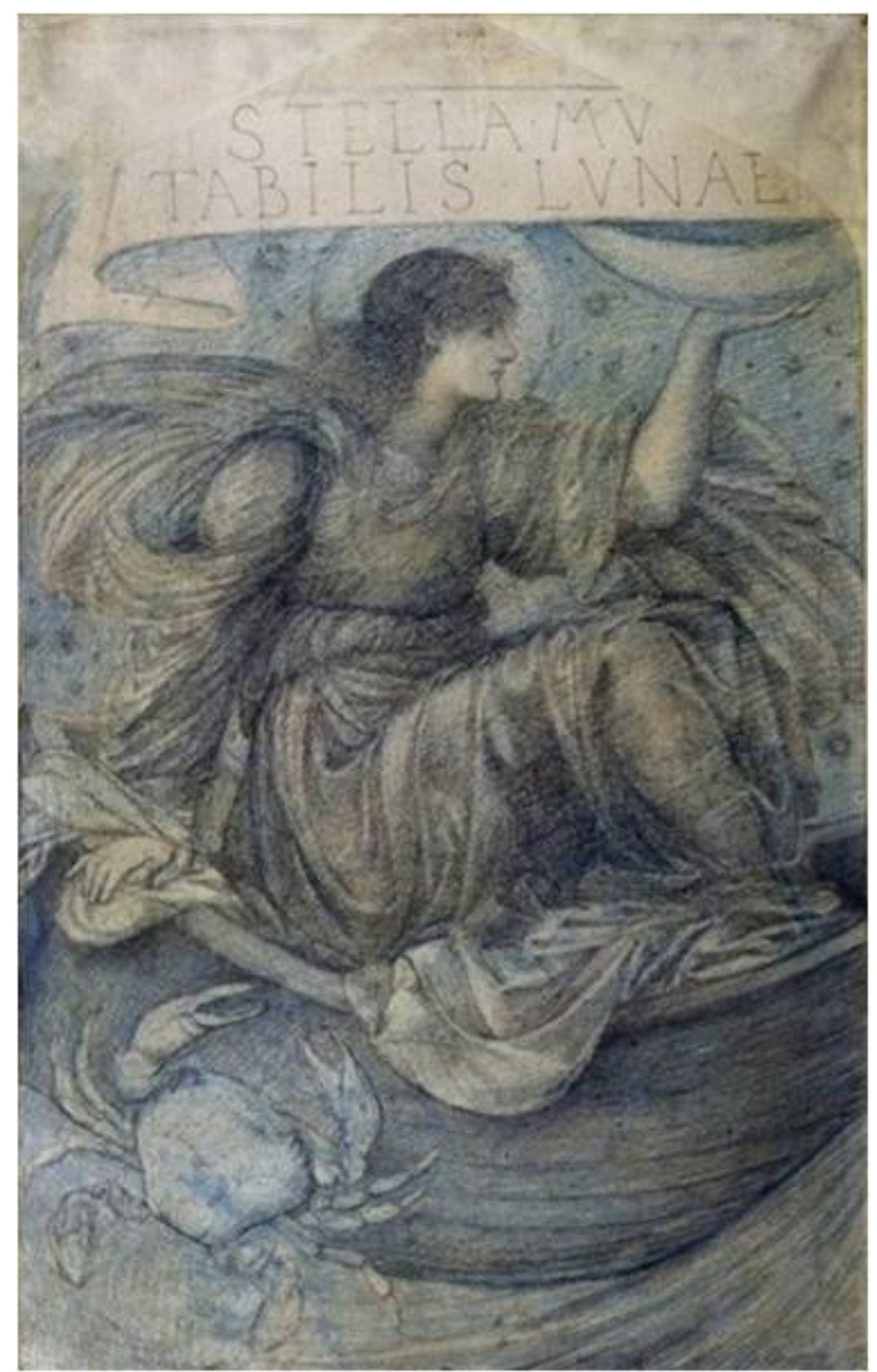

Figure 3. Edward Burne-Jones, Luna (Moon) (Stella Mutabilis Lunae), 1879, cartoon.

The cartoons for the nine planets suffered a less tragic fate than their companion stained-glass panels. They were dispersed after being used, but today their locations are known. In 1930, Torre Abbey was a historic site with private collections. According to Rhodes, the art collector G. H. Earle of Rocklands, residing at Warren Road in Torquay, purchased seven of Burne-Jones's cartoons of the Planets-Venus, Luna, Sol, Jupiter, Saturn, Earth, and Evening Star-from Angus Holden's wife, Lady Holden (see Figures 2-3, 5-6, 8-10). ${ }^{10}$ In early 1930, Earle donated these cartoons to the Torre Abbey collection, which became a museum in $1936 .{ }^{11}$ In

${ }^{10}$ See Rhodes, Devon's Torre Abbey: Faith, Politics and Grand Designs, Introduction.

11 After the death of Angus Holden in 1912, his wife and family moved to Torquay. After the death of her mother, Donna Holden lived for a long time in a nursing home. Prior to her death in 1995, the curator of Torre Abbey Museum contacted her, but she provided no information about Burne-Jones's Planets cycle. See Archive, Accession Number A-111, Torre Abbey Museum, notations made by Michael Rhodes, then Curator of the Museum. 
honor of Torre Abbey Museum's 50th anniversary in 1966, one of the Burne-Jones's original cartoons, Earth, was once again transformed into stained-glass (compare Figures 8 and 11). The eighth cartoon, Mars, was acquired through Christie's in 1898 by the Birmingham Museum and Art Gallery as part of the drawing collection (see Figure 7), ${ }^{12}$ and the ninth cartoon, Morning Star, is presently located at Lady Margaret Hall in Oxford (see Figure 4).

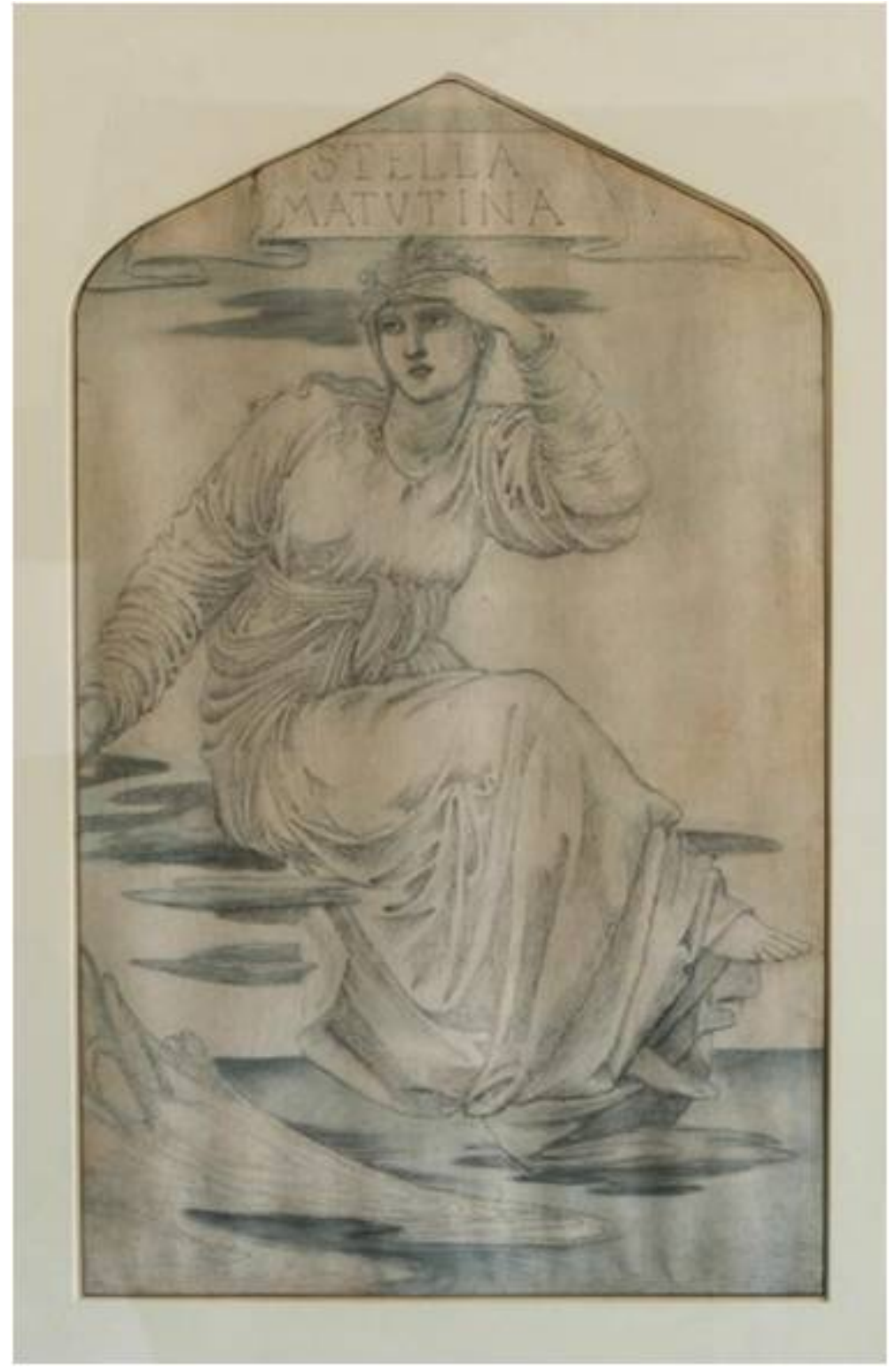

Figure 4. Edward Burne-Jones, Morning Star (Stella Matutina), 1879, cartoon.

12 See Registrar's notation at the Birmingham Museum and Art Gallery. See also Cheney, "Edward Burne-Jones's The Planets." 


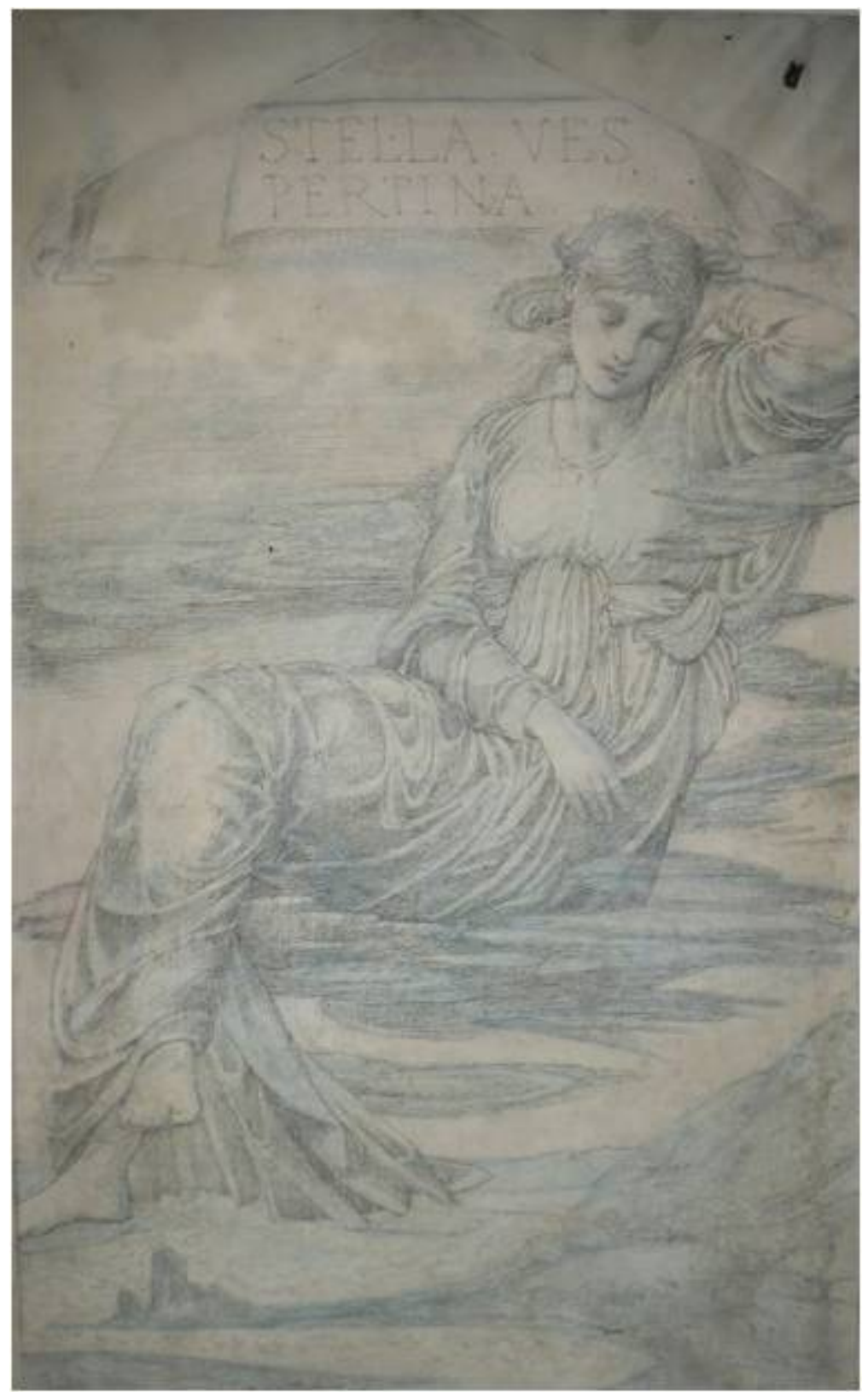

Figure 5. Edward Burne-Jones, Evening Star (Stella Vespertina), 1879, cartoon. 


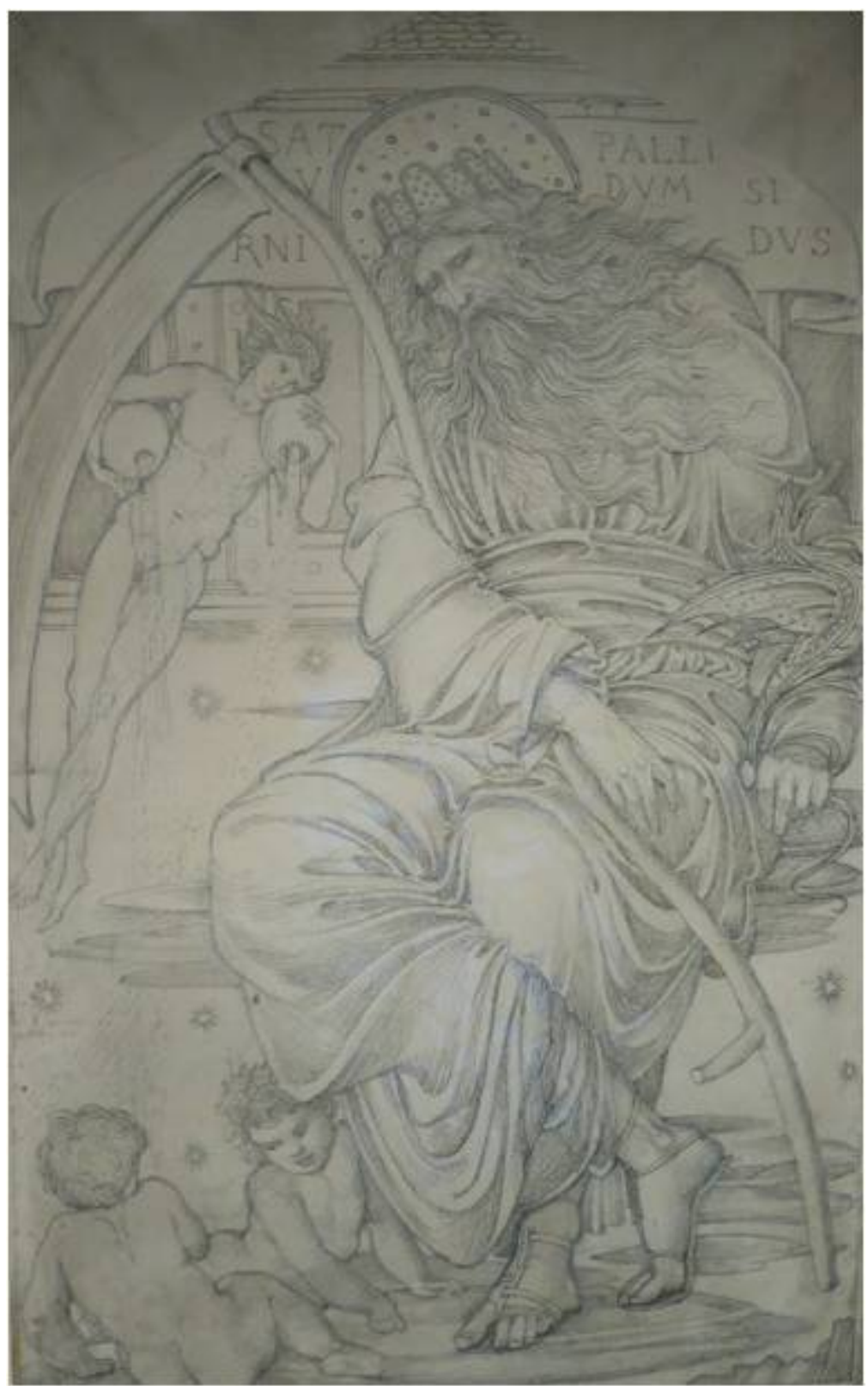

Figure 6. Edward Burne-Jones, Saturn (Saturn Palladium Sidus), 1879, cartoon. 


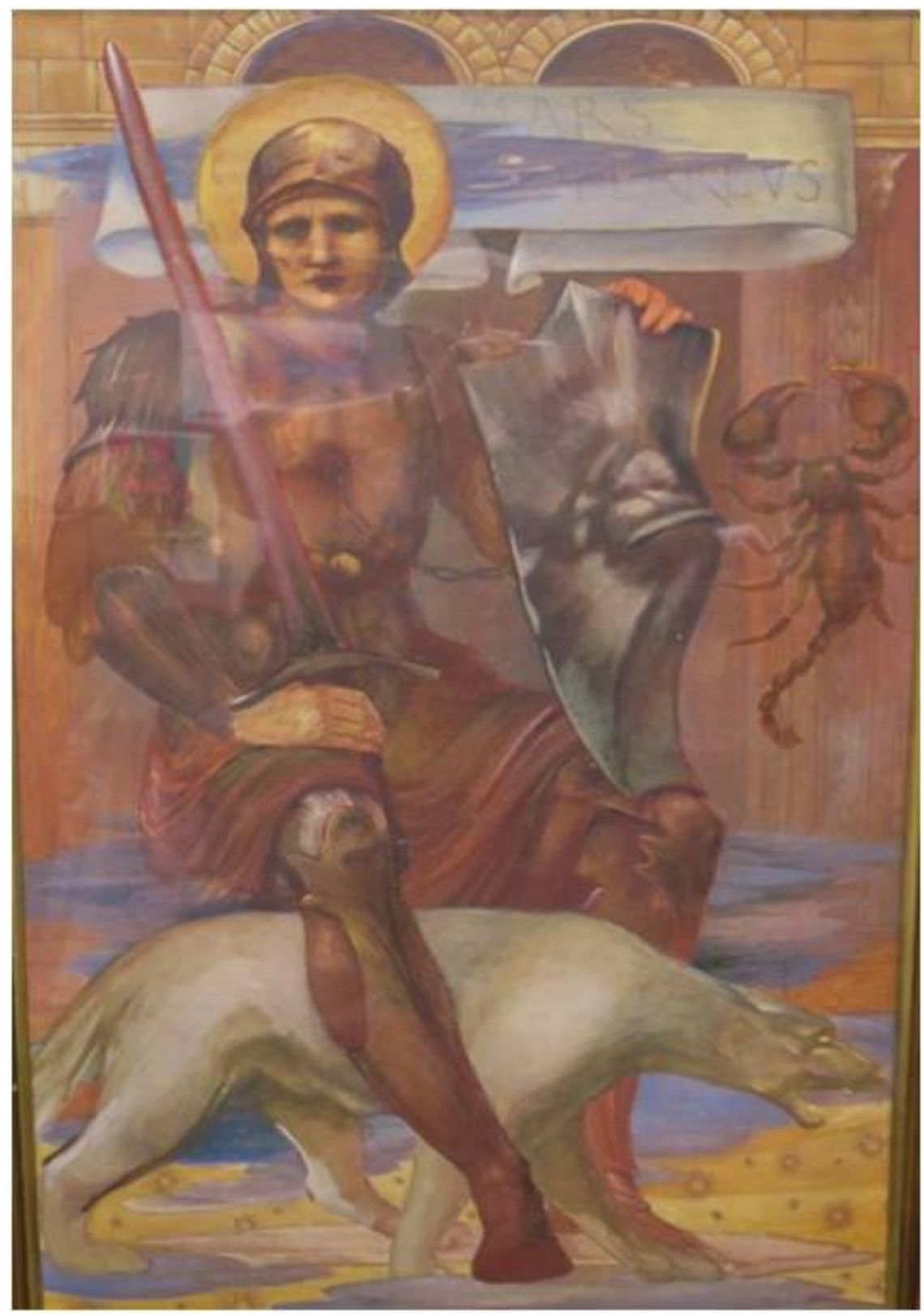

Figure 7. Edward Burne-Jones, Mars (Mars Terreus), 1879, cartoon. 


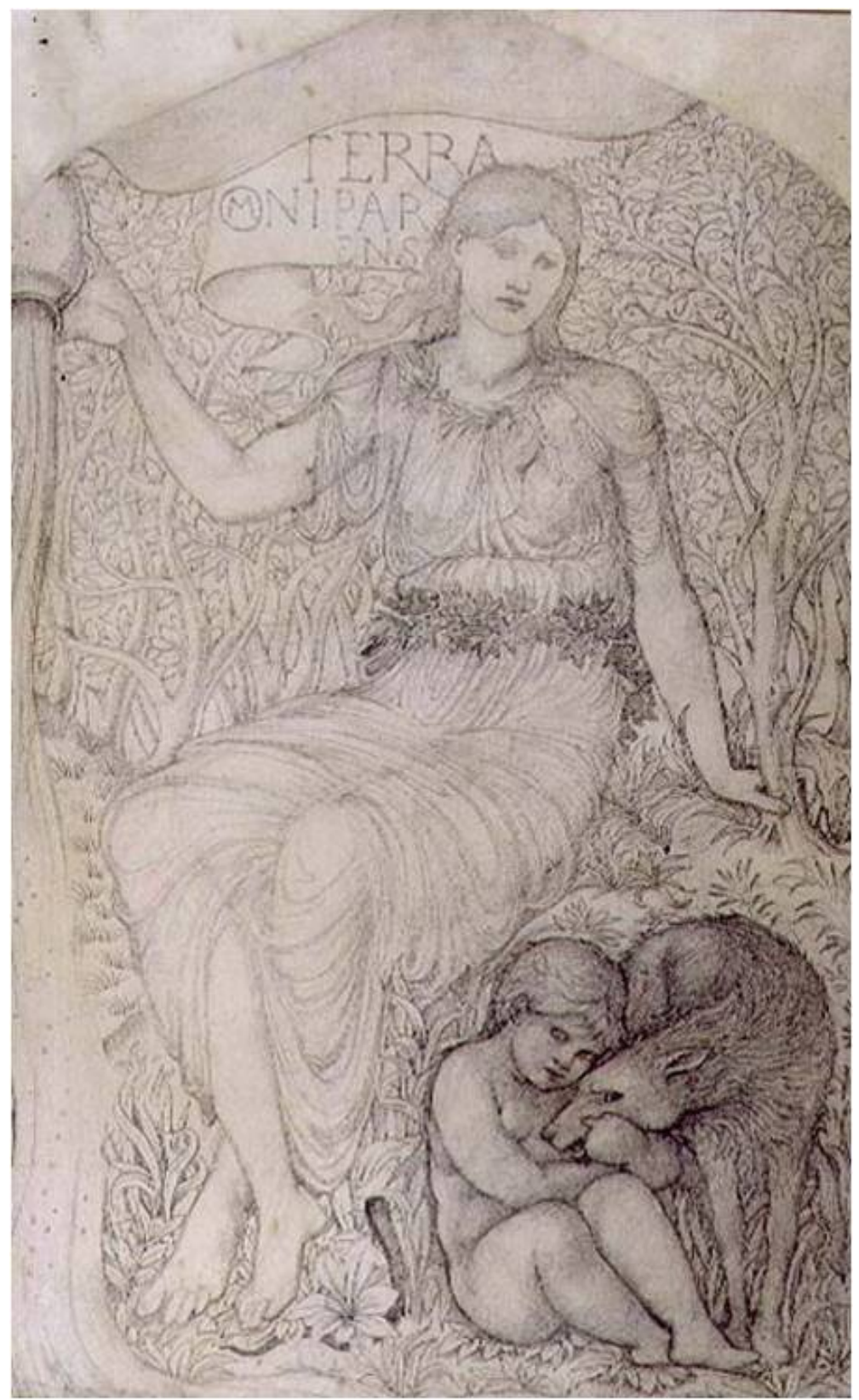

Figure 8. Edward Burne-Jones, Terra (Earth) (Terra Omniparens), 1879, cartoon. 


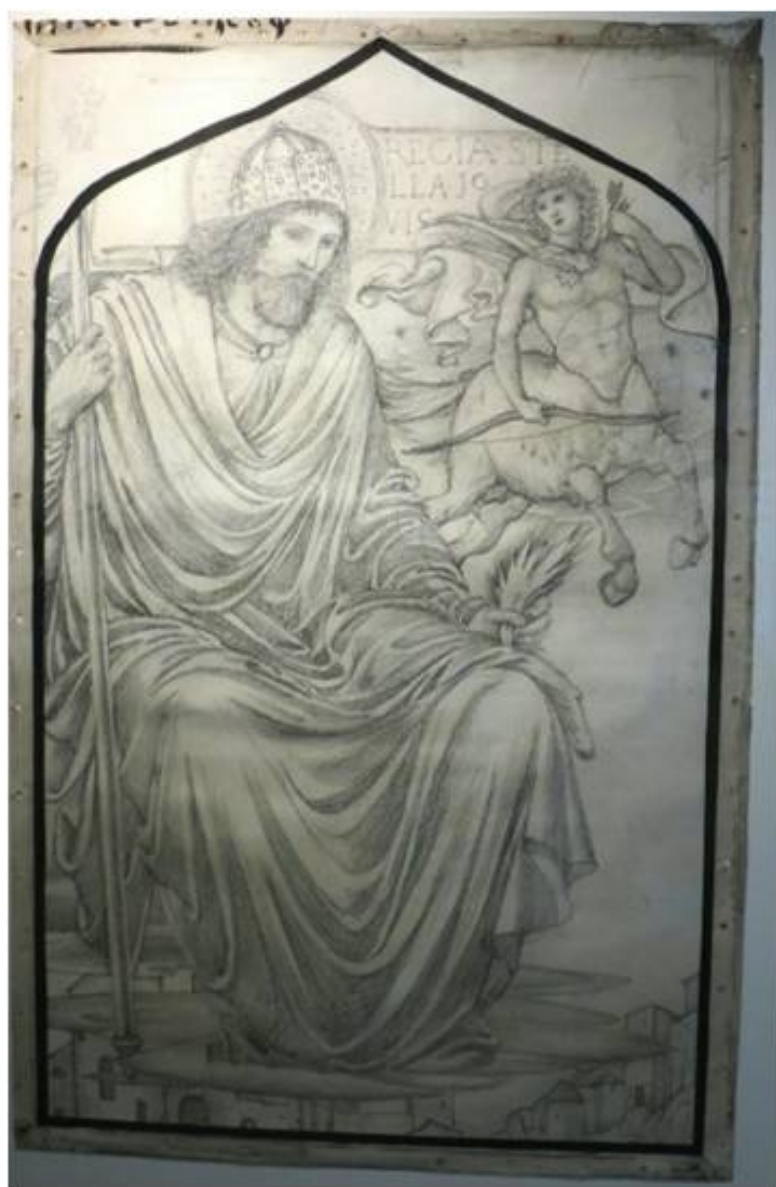

Figure 9. Edward Burne-Jones, Jupiter (Regia Stella Jovis), 1879 , cartoon.

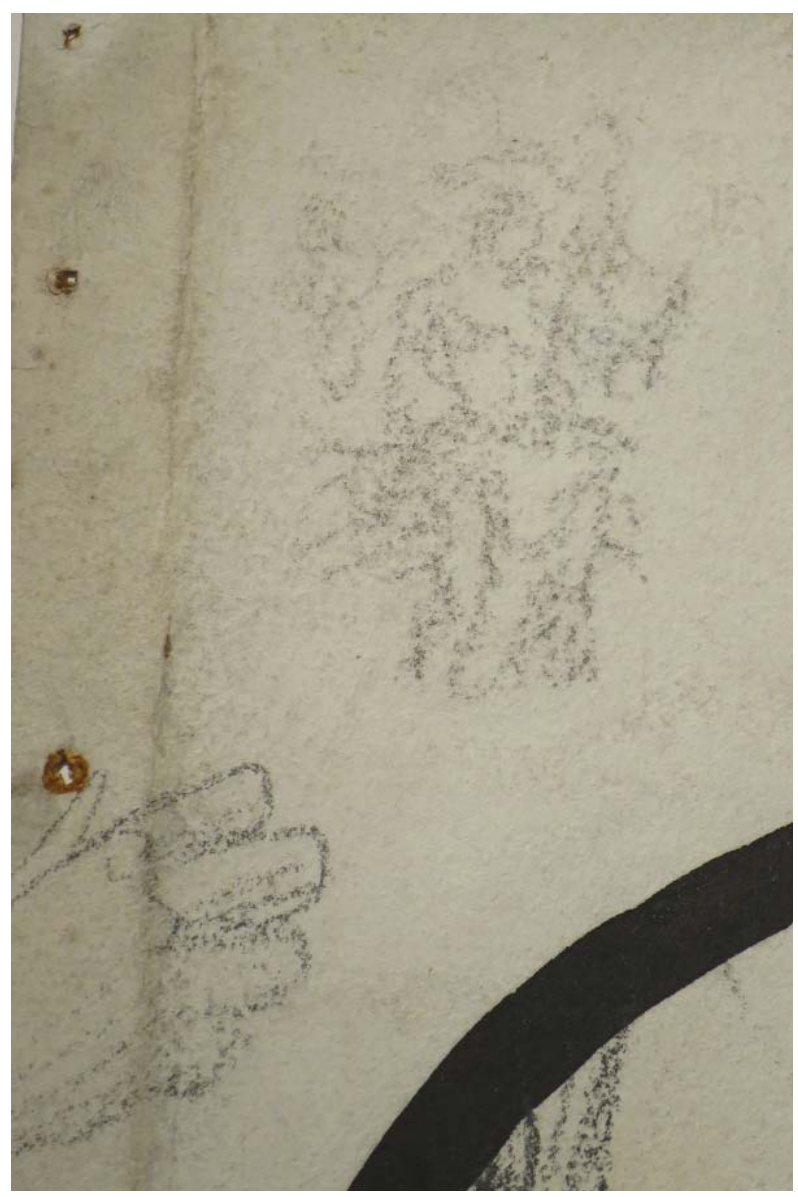

Figure 9b. Edward Burne-Jones, Jupiter (Regia Stella Jovis), det., 1879, cartoon. 


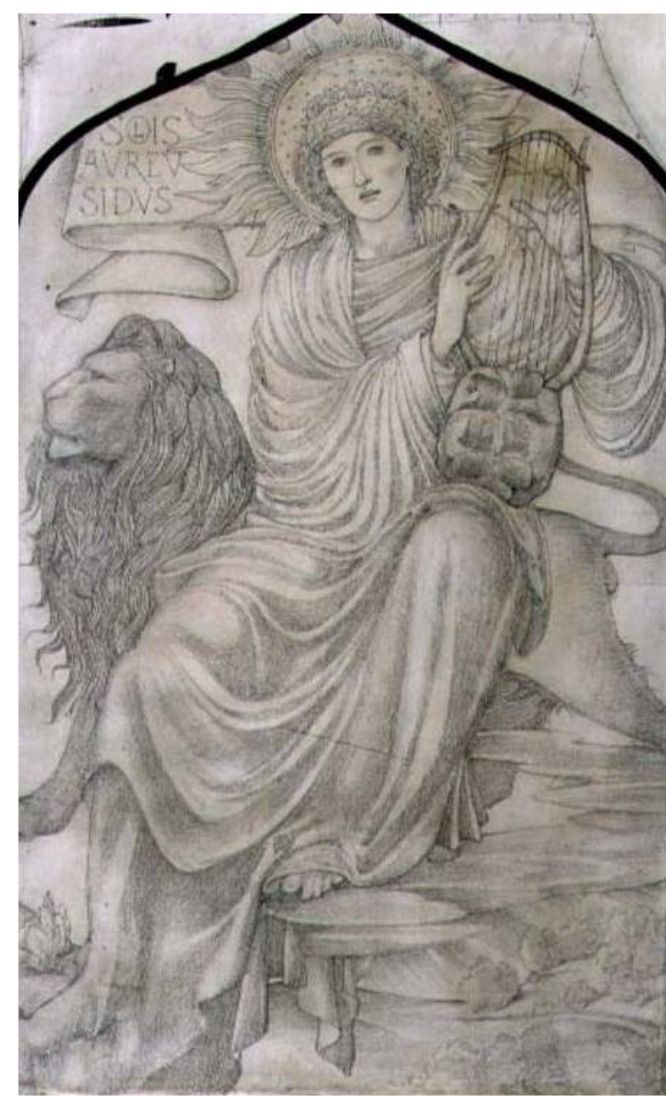

Figure 10. Edward Burne-Jones, Sun (Apollo) (Solis Aureus Idus), 1879, cartoon.

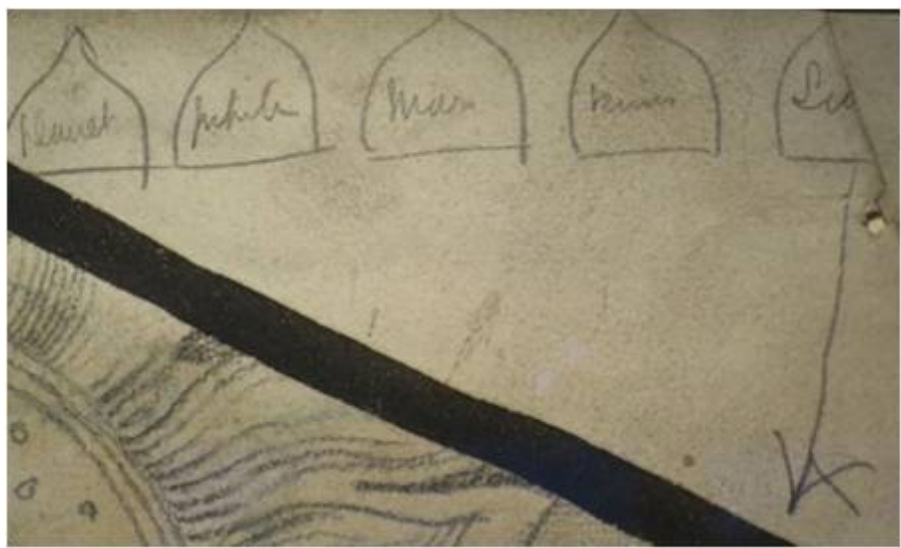

Figure 10b. Edward Burne-Jones, Sun (Apollo) (Solis Aureus Idus), det., 1879, cartoon 


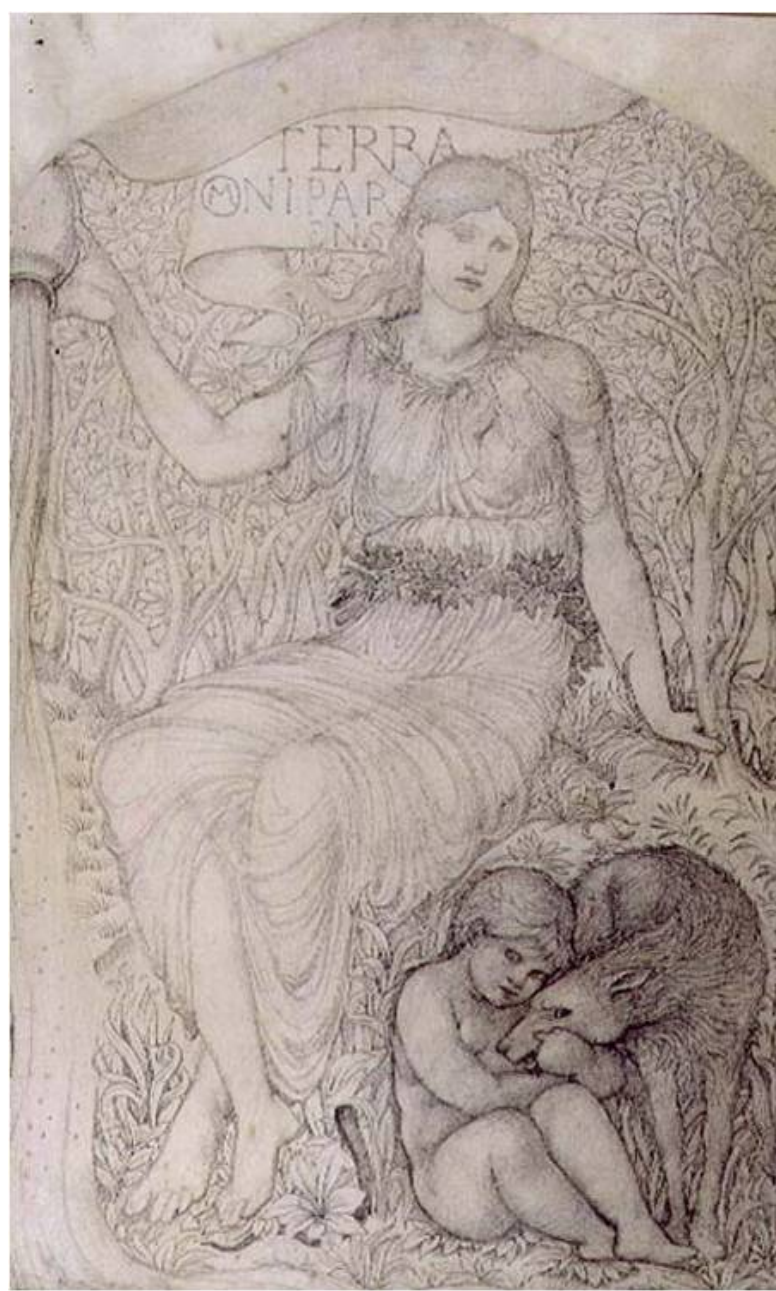

Figure 8. Edward Burne-Jones, Terra (Earth) (Terra Omniparens), 1879, cartoon.

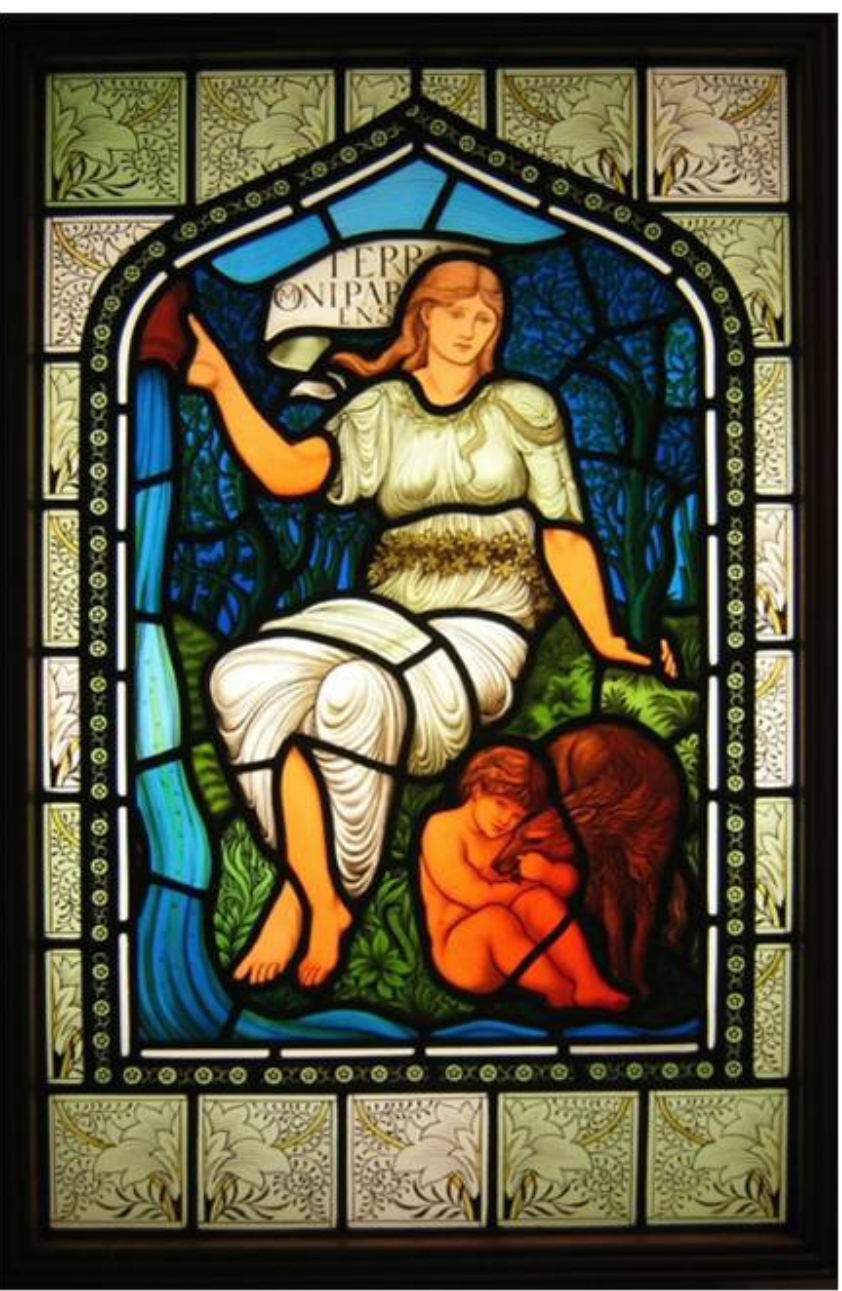

Figure 11. Edward Burne-Jones, Terra (Earth) in glass panel. Torre Abbey Museum, 1996.

\section{Stylistic and Iconographical Observations About the Planets Cycle}

Burne-Jones's method of composing a work of art is noteworthy. His creations are inventive, carefully executed, and slowly finished. He commenced with drawing his conception in pencil or chalk, deliberating on the conceit, making alternative artistic changes, composing new inventions, and continuing to design elaborate studies for further consideration. Then, from the almost complete chalk or pencil drawing, Burne-Jones repeated the same artistic concept in small color sketches in chalks or watercolors, exploring artistic nuances. From these evolved designs he expanded the image from a small-size drawing into a large cartoon in pencil, chalk, or watercolor. This cartoon usually was of the same size as the painting. During this creative process, Burne-Jones composed numerous studies, analyzing meticulously the artistic selections and resolutions. The Planets cycle is an excellent example of Burne-Jones's painstaking artistic process. ${ }^{13}$

\footnotetext{
${ }^{13}$ See Malcolm Bell, "Sir Edward Burne-Jones," in A Biographical Dictionary of Painters and Engravers, Robert Edmund Graves (Ed.), 2 vols. (London: George Bell and Sons, 1809-1918), 1: 217-219. The perforations along the edges of the cartoon suggest their usage when copied and transferred them into glass panels. Discussion on the notation will be included in the description of each cartoon of the Planets cycle.
} 


\section{The Seasons Cycle: Earlier Conception for the Planets Cycle}

The Planets cycle was early conceived as part of a Seasons cycle, which was first designed in 1864, completed in 1868 as "four drawings of the Seasons in red chalk," and expanded in 1869 as a series of watercolors, including individual personifications of the seasons. ${ }^{14}$ This version of the seasons was exhibited at Grovesnor Gallery in 1878, becoming part of Frederick Richards Leyland's collection of art, which was then sold by his estate in 1892 (see Figures 12-15). ${ }^{15}$

In the Seasons cycle, Burne-Jones's vertical compositional design and viewing di sotto in su (from below up) the pictorial form derives from nineteenth-century Japanese $\operatorname{art}^{16}$ and Italian Renaissance art and engravings. ${ }^{17}$ In the drawing of the Seasons cycle, Burne-Jones continues to show the influence of Italian Renaissance. ${ }^{18}$ To some extent Burne-Jones followed the conception that Baccio Baldini expressed in his The Planets and Their Children, engraving edition of 1460 (inv. 1585-1591) at the Museo Civico in Pavia. ${ }^{19}$ But Baldini focused on the terrestrial landscape of the season and its astral zodiacal influence, while Burne-Jones focused on the imagery, removing the psychological influences and ramifications on the individual's astral chart. Baldini's engravings are an example of the type of pictorial form where the design is composed to be seen from below up. The engraver depicted a geocentric or Ptolemaic conception of the universe, where seven planets transit around the earth, including the Moon, the Sun, Mercury, Venus, Mars, Jupiter, and Saturn. These planets, depicted as personifications, control the activities of those individuals born under their astral cycle. Baldini composed the imagery of each planet as a symphonic crescendo: at the bottom of each design there is an extensive description explaining the influence of the planets on the temperaments and inclinations of individuals born under this planetary cycle. Above this written description there is a visualization of the numerous activities performed by "the children" born under this planet in the terrestrial realm. At the top, in the celestial realm, the personification of the planet transits across the sky in an elaborate chariot, supervising and ruling over the terrestrial realm.

In Burne-Jones's Seasons cycle, each season is composed of a pictorial design that begins at the bottom with Mantegna-like putti (cupids) holding a scroll with a Latin inscription. Above them a landscape defines the season, while at the top of this terrestrial landscape a large inscription identifies the ruling planet. This crowned celestial ruler is seated on clouds, holding appropriate attributes. The ruling planet's astral sign appears above. Between the ruling planet and its corresponding sign, a zodiacal band, containing the season's astrological

\footnotetext{
14 See Georgiana Burne-Jones, Memorials of Edward Burne-Jones, 2 vols. (London: Macmillan Company, 1904), 2: 9, hereafter cited as GBJ Memorials. In a letter of 1868 to Frederick Richards Leyland (1831-1892), Burne-Jones acknowledged that he had completed "the whole scheme of The Seasons-Spring, Autumn, Summer and Winter." Burne-Jones expressed his wish that each of the set be kept together in one room, stating: "I think they would make a nice set of decorative pictures for one room." A place was arranged in Leyland's home, which was the dining room. Leyland was a wealthy British ship-owner and avid collector of Pre-Raphaelite art, including Dante Gabriel Rossetti.

15 See Bell, Edward Burne-Jones: Record and Review, 34 and 102.

16 See Ayako Ono, Japonismein Britain: Whistler, Menpes, Henry, Hornel and Nineteenth-Century Japan (London: Routledge Curzon, 2003); Stephen Wildman (Ed.), Waking Dreams: The Art of the Pre-Raphaelites from the Delaware Art Museum (Alexandria, VA: Arts Service International, 2004), 224, 286, 365 (Japanese art was first displayed in London in 1862 at South Kensington, 224); Stephen Wildman and John Christian, Edward Burne-Jones: Victorian Artist-Dreamer (New York: Metropolitan Museum of Art, 1998), 114-116; and Martin Harrisons and Bill Waters, Burne-Jones (New York: Putnam's Sons, 1973), 112-114, 133.

17 Burne-Jones's inspiration from Italian art is well noted. See GBJ Memorials, 1: 200 and 2: 23.

18 See Harrisons and Waters, Burne-Jones, 56-58, 77, 84, 94, 104, 107, 115-116, 144-146.

19 See Mark J. Zucker, The Illustrated Bartsch, Early Italian Masters (New York: Abaris, 1980), vol. 24, Commentary on Baccio Baldini (c. 1436-1487). Also note that in the composition of Venus and Cupid, Burne-Jones recalled Michelangelo's Bruges Madonna of 1501-1504, in the Church of Our Lady in Bruges.
} 
signs, is diagonally placed, alluding to the changes of seasons through time and space. ${ }^{20}$

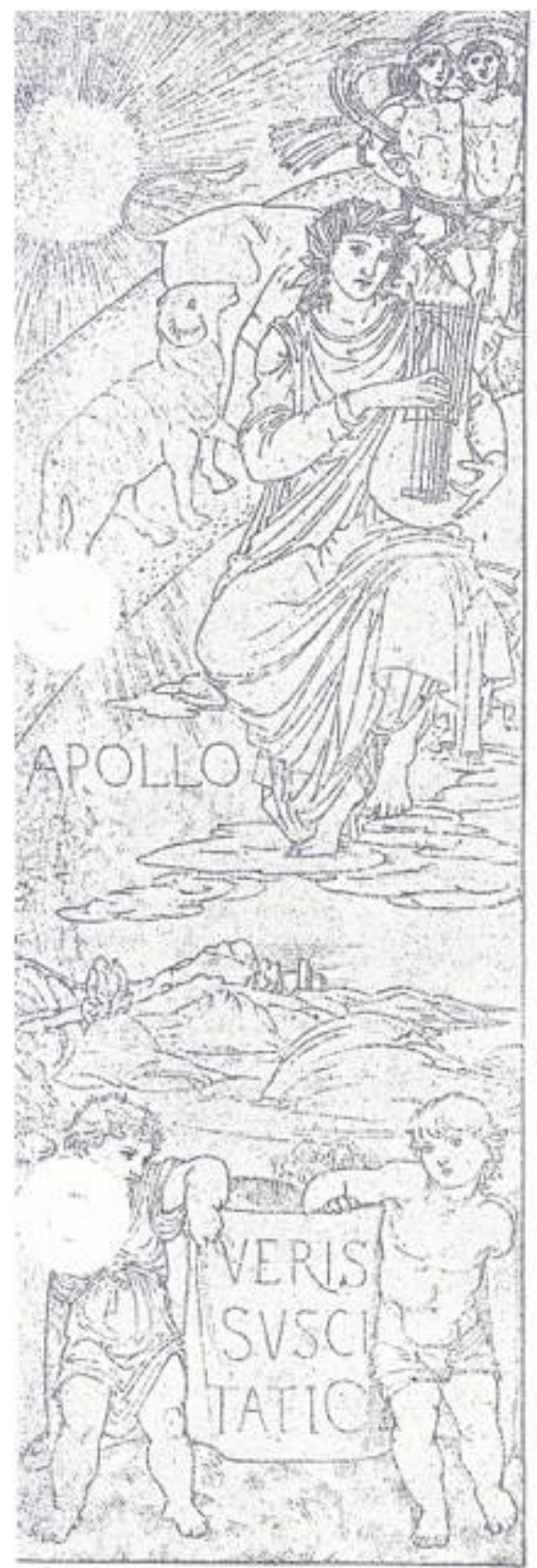

Figure 12. Edward Burne-Jones, Spring (Apollo), 1868.

The season of Spring is announced by two Mantegna-like putti, one clothed and the other mostly nude; they are holding a large scroll with the Latin inscription Veris suscitatio (Awakening Spring, see Figure 12). Above them is a view of a hilly landscape with vegetation, with a citadel visible in the distance. The ruling planet Apollo, the Sun God, resides in the sky; his radiant sun's rays bathe the whole scene. Seated on clouds and crowned with laurel, Apollo plays the lyre, announcing with music the season of Spring. The zodiac signs

${ }^{20}$ See Morris Hickey Morgan (Ed.), Vitruvius, The Ten Books On Architecture (New York: Dover, 1960), 256-270, for a classical description of the zodiac signs and planets. 
in the zodiacal band signify Apollo's astral influence on creators, poets, musicians, and lovers of beauty. These depictions correspond with the months of the calendar year and include the ram Aries (March); the bull Taurus (April); and the twins Gemini (May).

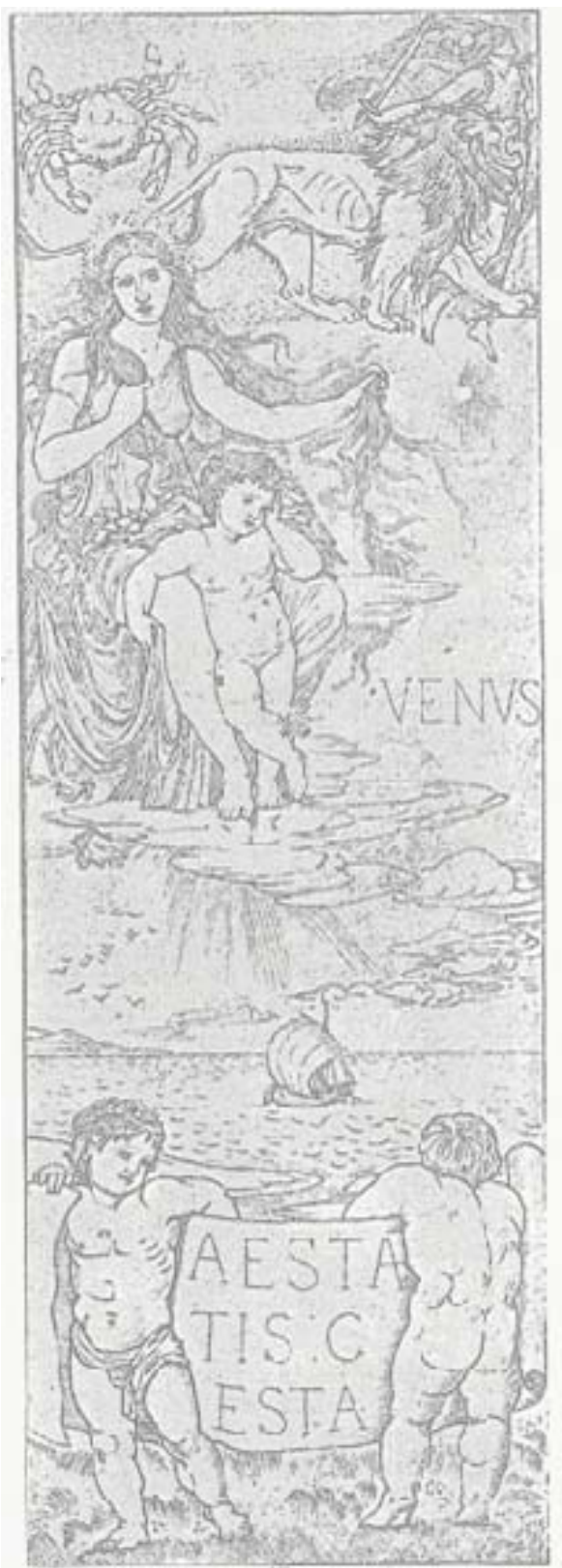

Figure 13. Edward Burne-Jones, Summer (Venus), 1868

The next depicted season is Summer. Two putti, one seminude and the other nude, wrap around a scroll with the Latin inscription Aestatis gesta (Summer Events, see Figure 13). The nude putto, seen from the back, looks at the seascape where a sailboat on rippling waters tranquilly voyages under a blazing sun. A cluster of birds flies along the few floating clouds. Celestial Venus, the governing planet, announces the beginning of the terrestrial season. Seated on a large cloud, a Botticelli-like Venus braids her long tresses. She is crowned with flowers as the astral ruler of the season. More blooming flowers are found on her lap, where her son Cupid rests 
against her knees. Above Venus, the summer signs of the zodiac form a trio, which moves slowly through the season: the crab of Cancer (June); the roaring lion as Leo (July); guided with the sword of a maiden, Virgo or the Virgin (August).

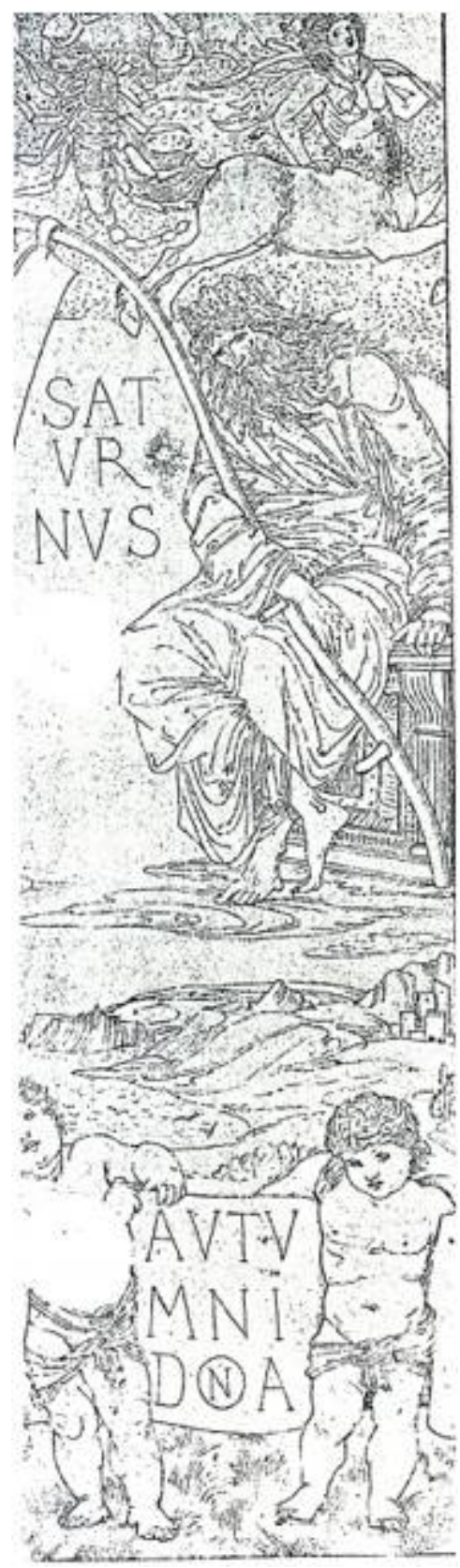

Figure 14. Edward Burne-Jones, Fall (Saturn), 1868.

The season of Autumn is identified by seminude putti holding a scroll with the Latin inscription Autumn idona (Suitable Autumn, see Figure 14), alluding to the vision of an extended coastal landscape with seashore, sea gulls gliding, and rocky cliffs hiding a citadel from view. Tired Saturn, the ruler of the astral season, is seated on a marble throne. His long beard alludes to his old age, while his royal crown suggests the passing of a golden season. While he is resting, he holds onto a large bladed scythe, a symbol of harvesting and the passage 
of time. Above Saturn, the signs of the zodiac that correspond to his astral season are the scales for Libra (September), a large scorpion for Scorpio (October), and the galloping centaur for Sagittarius (November).

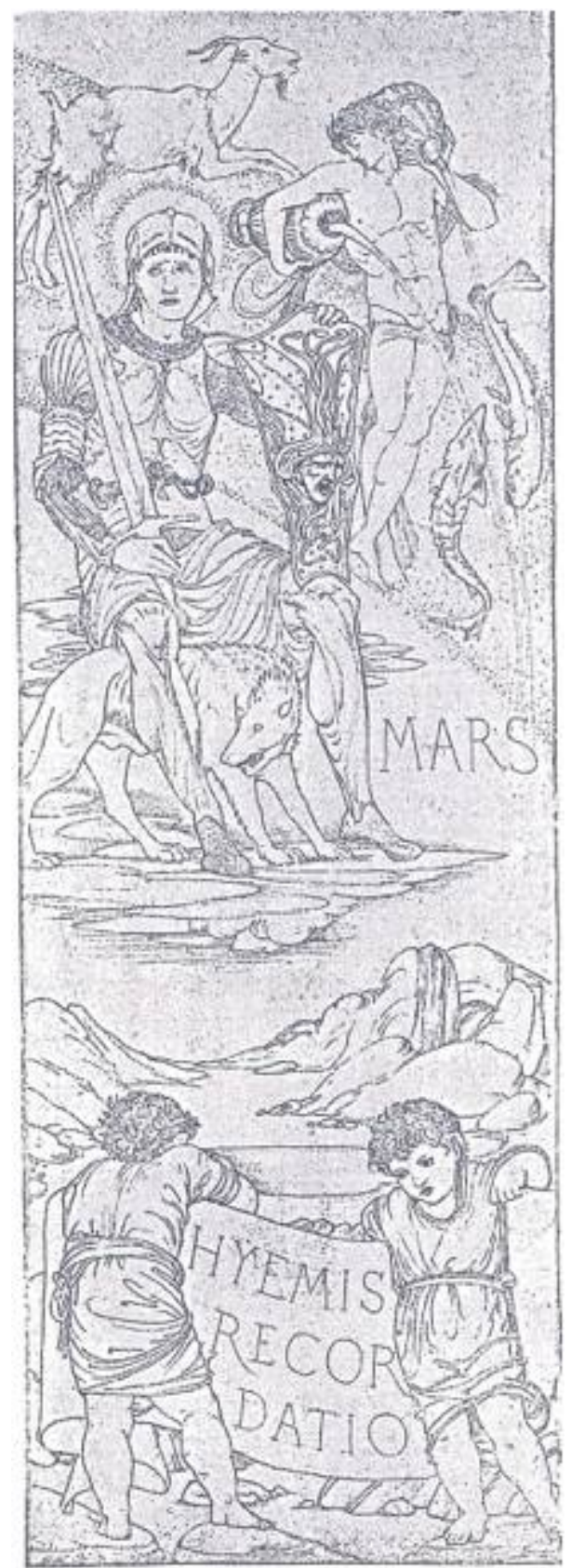

Figure 15. Edward Burne-Jones, Winter (Mars), 1868. 
The Seasons cycle is completed with Winter. The two putti, now both fully draped, are in reverse position from the putti of Summer. They rest on a scroll with the Latin inscription Hyemis recordation (Rigors of Remembrance, see Figure 15). Burne-Jones depicted a desolate seascape, barren mountains, and lack of any lifelike existence. Seated on a cloud in full armor, Mars is the astral planet of winter. His animal companion, a grim wolf, reinforces the harsh cold symbolism. ${ }^{21}$ Mars is at rest. In one hand he holds a sword upright and in the other a shield, which is chained to his breastplate. The shield is designed with a relief of a Medusa's head that freezes and transforms into stone those who gaze at her image. The zodiacal band shows the running goat of Capricorn (December) and the water-bearer of Aquarius (January), who with one vessel under his arm and another held on his shoulder provides water for the diving fishes of the zodiac sign of Pisces (February).

Although inspired by the compositions of the Seasons cycles, the Planets cycle elaborates on the astral aspects of the planets. Burne-Jones created a background for their compositions with stars and seated the personifications of the planets on clouds, embracing or resting on their dominant zodiac sign and holding their respective astral attribute. The terrestrial and seasonal landscape is reduced to a minimum. In the Seasons cycle the Latin inscriptions referred to seasonal transformations, whereas in the Planets cycle the inscriptions announce the planet's sovereignty. Burne-Jones focused on the astral nature of the planets but only on the dominant zodiac sign of each. He replaced the zodiacal band of the Seasons cycle with the depiction of the dominant zodiac sign associated with the planet, e.g., the bull (Taurus) with Venus; the crab (Cancer) with Luna; the lion (Leo) with Apollo; the scorpion (Scorpio) with Mars; the water-bearer (Aquarius) with Saturn; and the centaur (Sagittarius) with Jupiter.

\section{The Planets Cycle}

Three entries in Burne-Jones's Account Books at the Fitzwilliam Museum record his progress on the project: (1) 18 August 1878: "First four figures of Planets. Pound 15 ea. viz. Venus, Luna, Morning and Evening Stars. Pound 60" (see Figures 2-5); (2) 22 August 1878: two more Planets were completed, "Saturn and Mars" (see Figures 6-7); and (3) 1 November 1878: complete "Figures of Earth, Jupiter and Apollo. Pound 45 " (see Figures 8-10). ${ }^{22}$

The description of the each Planets cycle in this essay follows the order listed in Burne-Jones's account entries. All the cartoons are drawn in pencil, charcoal, and colored chalks. Most are framed with a bold black line culminating in an arch shape (Tudor arch) atop, indicating the glass-panel design. The Planets cycle's compositions are designed with a lower or foreground area with a seasonal landscape and a middle or middle ground area with a planetary deity seated on a respective zodiac sign. The personifications of the planetary deities are crowned and wear a specific type of celestial halo while holding an additional symbolic attribute that identifies the nature of the astral deity. Most backgrounds are decorated with scattered shining stars. At the top of each composition, a large scroll with a Latin inscription affirms the deity's sovereignty and provides the

\footnotetext{
${ }^{21}$ See Whitworth Wallis and Arthur Bensley Chamberlain, Illustrated Catalogue with Descriptive Notes of the Permanent Collection of Paintings and Sculpture, and the Pictures in Aston Hall (Birmingham: Hudson and Son, 1904). The drawing on the Season of Winter (Mars) is mentioned in connection with the cartoon of Mars from the Planets cycle.

22 See Malcolm Bell, Edward Burne-Jones: A Record and Review, 102-02, for a discussion of four designs on the Seasons cycle as an earlier conception for the Planets cycle. There were two drawings for the planet Sol, a variant of an Apollo cartoon. In most of the Planets cycle cartoon's margins there are handwritten notations with the word Woodlands. However, some scholars concur that these notations are not in Burne-Jones's handwriting. I disagree. Probably Burne-Jones made these instructional notations to assist the glassmakers. Perhaps the stained-glass artists also made additional notations. I am grateful for the assistance of the Curator of Drawings from the Fitzwilliam Museum in Cambridge.
} 
clavis interpretendi for the astral symbolism. The planetary divinities rule both terrestrial and celestial realms, and their corresponding attributes allude to this dual conceit. Interestingly, some of the Planets cycle's cartoons contain notations and instructions for the artisan transferring the image into a glass panel. The lateral perforations of the cartoons are further indications of the media-transferring process from pencil to glass. In conception, the Planets cycle is a derivative creation from the compositions of the Seasons cycle but focusing on astral sovereignty. It is possible that Burne-Jones also conceived a separate Zodiac cycle as part of the Woodlands' window, or perhaps he integrated that conceit with the Planets cycle, as noted in this essay. ${ }^{23}$

A brief analysis of each individual planet depicted in Burne-Jones's Planets cycle assists in understanding his furor artisticus (creative process) and furor poeticus (intellectual inspiration). He used classical metaphors of astronomy to express his artistic quest for a canon of art. ${ }^{24} \mathrm{He}$ held fast to one goal: "To love beauty." He noted: "Only this is true, that beauty is very beautiful and softens, and comforts, and inspires, and rouses, and lifts up, and never fails." ${ }^{25}$ In this he echoed the Italian Renaissance theory of art or Neoplatonism. In this philosophy, "beauty consists of a certain charm" as something spiritual that transcends sensual experience and makes us long for the origin of what we perceive. ${ }^{26}$ Burne-Jones explained what art is for him:

I mean by a picture a beautiful, romantic dream of something that never was, never will be - in a light better than any light that ever shone — in a land no one can define or remember, only desire — and the forms divinely beautiful—and then I wake up. ${ }^{27}$

The astral imagery of Burne-Jones's Planets cycle wonderfully reveals his pursuit for art and beauty.

\section{The Planet Venus, Stella Candida Venere}

The cartoon for the personification of the planet Venus is designed with an arch-shaped frame, which is edged in black ink (see Figure 2a-c). Burne-Jones's overall compositional coloration is a fusion of gold and blue tonalities with the exception of the reddish-brown tints in the lower part of the drawing. Inside the design at top there is a large scroll with a Latin inscription, Stella Candida Venere, identifying the planet Venus as a brilliant star. The heading is the clavis interpretendi for the imagery. In a starry sky, a young, beautiful female transits the heaven while riding on a bull. In their astral navigation, they both touch the earth: both the bull and Venus have a foot resting on earth while the other is suspended on air, thereby alluding to their dual roles as heavenly and earthly creatures. Venus is dressed in classical and Renaissance attire with the motif of "wet drapery" modeling her body. A gold and tooled nimbus surrounds her head, creating an aura of divinity. She is

\footnotetext{
23 See Sewter, The Stained Glass of William Morris and His Circle, 208.

${ }^{24}$ I am associating Burne-Jones's creative inspiration with the Platonic and Renaissance Neoplatonic concept of furor poeticus (poetic inspiration), which derives from the writings of the Greek philosopher Plato (d. 348 BCE) that were translated and commented upon by Marsilio Ficino (1433-1499), an Italian Renaissance physician and philosopher. Ficino explained in his Orphic writings and Commentary on Plato's Symposium (7: 14) that there are "four divine furors: first poetical, then mythical, third prophetic and amorous fourth" ("Quatuor ergo divini furoris sunt speties. Primus quidem poeticus furor, alter mysterialis, tertius vaticinium, amatorious affectus est quartus"). See Michael J. Allen, The Platonism of Marsilio Ficino (Los Angeles: University of California Press, 1984), 41-67; Paul Oskar Kristeller (Ed.), The Letters of Marsilio Ficino, 3 vols. (New York: Ginko, 1985), 1: 14-20, in particular, Marsilio Ficino's letter to Peregrino Agli on De divino furore; and see Liana De Girolami Cheney, "Giorgio Vasari's Fine Arts from the Vite of 1550," Journal of Literature and Art Studies 7 (February, 2017 ): 162.

${ }^{25}$ See William Gaunt, The Pre-Raphaelite Tragedy (New York: Harcourt, Brace and Company, 1942), 152; and Robin Spencer, The Aesthetic Movement: Theory and Practice (London: Studio Vista, 1972), 37.

${ }^{26}$ See Marsilio Ficino, Symposium, I. 3, in Opera omnia (Basel: Janus Cornarius, 1561); and for a study on the impact of Marsilio Ficino's Neoplatonism and Renaissance art, see Liana Cheney, Botticelli's Neoplatonic Images (Potomac, MD: Scripta Humanistica, 1993).

27 See David Cecil, Visionary and Dreamer: Two Poetic Painters, Samuel Palmer and Edward Burne-Jones (Princeton: Princeton University Press, 1969), 143, quoting from a letter Burne-Jones wrote to Morris.
} 
also crowned with a large hair-band that holds together her tresses and accentuates her forehead, which is decorated with a seashell and a pearl. These aquatic attributes relate to Venus's divine birth from the sea. ${ }^{28}$ They also allude to the terrestrial nature of the deity as born from the fertility and union of the sea and the sky. ${ }^{29}$ While the bull raises his head to glance at the radiance of the stars, alluding to his astral nature as celestial Taurus, ${ }^{30}$ Venus lifts a mirror to admire her reflection. The mirror alludes to the luminosity that Venus emanates as an astral and physical form. ${ }^{31}$ As a symbol of natural and physical luminosity, Venus gazes at the mirror to observe her dual nature: her physical beauty (venustas) as a female; and her spiritual beauty (love) as a deity. ${ }^{32}$ Venus's supernatural reflective light expresses her planetary nature, while her image in the mirror displays her natural attractiveness. The mirror also reveals Venus's inherited celestial and spiritual powers of light and darkness as cosmic physical transitions from the gods of the Morning and Evening stars: Eosphorus, morning light, to Hesperus, the evening light. ${ }^{33}$ Burne-Jones visualized this conceit in depicting a seascape with these light variances at the bottom of the imagery, in the area of earth.

Venus as an astrological planet rules the house of Taurus, personified as a constellation as well as a zodiac sign with the bull. ${ }^{34}$ The earthly depiction of the bull's nature is manifested in the brown coloration of the animal's body as well as the mountainous landscape surrounded by seashore at the base of the design. The bull as a sign of earth combines the principles of creativity, fertility, and masculinity, thus balancing Venus's feminine creativity and fertility. Burne-Jones also conveyed the dual roles of Venus and the bull by depicting between them a pair of scales - the zodiac sign for the constellation of Libra. Astrologically, Venus rules not only the house of Taurus but also that of Libra. ${ }^{35}$ The pair of scales is the only zodiac sign that is an inanimate object, a non-animal form. But the geometric shape of the scales as cups represents human breasts, hence alluding to Venus's female nature. The concave space of the cups alludes to a hemispherical balance. In the

\footnotetext{
${ }^{28}$ See John Mulryan, Vincenzo Cartari, Images of the Gods of the Ancients: The first Italian Mythographer (Tempe, AZ: ACMRS, 2012), 406-407. For the influence of Cartari's Images in pre-Raphaelite's art and poetry, see p. xxviii. Mulryan noted that Dante Gabriel Rossetti employed Cartari's Images in his art because his father owned a copy. Today this copy is located in the Avery Library at Columbia University (edition from Venice, 1647, call \#A7760 C242). Mulryan also noted that William Blake's imagery was influenced by Cartari's Greek and Roman mythology. Burne-Jones trained in the classics at Oxford and with the artistic connections of Rossetti and the Pre-Raphaelites undoubtedly had knowledge of Cartari's planetary conceits and text. See also Jean Seznec, The Survival of the Pagan Gods, Barbara F. Sessions (Trans.) (New York: Harper and Row, 1953), 258-262; and Jean Seznec, "Le manuels mythologiques et leur diffusion en Angleterre à la fin de la Renaissance," Mélanges d'histoire d'archéologie 50 (1953): 276-292.

29 See Hesiod, Theogony, Glenn W. Most (Ed.) (Cambridge, MA: Harvard University Press, Loeb Classical Library, 2007), lines 153-206, esp. 173; and William Sale "Aphrodite in the Theogony," Transactions and Proceedings of the American Philological Association 92 (1961): 508-521.

30 See Giuseppe Maria Sesti, The Glorious Constellations: History and Mythology (New York: Harry N. Abrams, 1991), 62-63, a reference to the Mithraism and Sumerian astronomy.

31 See J. C. Cooper, An Illustrated Encyclopaedia of Traditional Symbols (London: Thames and Hudson, 1978), 106; and Jean Chevalier and Alain Gheerbrant, A Dictionary of Symbols (London: Blackwell, 1994), 131, 464, 924.

${ }^{32}$ Venustas is a complex concept about beauty based on Vitruvius's theory of beauty and delight in architecture. Venus as a planetary star becomes symbol of light and beauty embodying the qualities of venustas. See Vitruvius, The Ten Books on Architecture, Morris Hickey Morgan (Ed.) (New York: Dover, 1960), 259; Anthony Grafton, Leon Battista Alberti: Master Builder of the Italian Renaissance (Cambridge, MA: Harvard University Press, 2000), 274-275; Anthony Blunt, Artistic Theory in Italy, 1450-1600 (Oxford: Oxford University Press, 1968), 15-18; Stefano Zuffi and Alessandra Novellone, Arte e Zodiaco: Storia, misteri e intepretazioni dei segni zodiacale nei secoli (Rome: Sassi, 2009), 67; and David Hanser (Ed.), Firmitas, Utilitas, Venustas: Architecture and Society (Dubuque, IA: Kendal Hunt, 1984).

${ }^{33}$ In antiquity, the planetary transit of Venus was viewed as formed by two different planets or stars: Vesperus, an Evening Star; and Eosphorus, a Morning Star. Burne-Jones included them separately in his Planets cycle. See Zuffi and Novellone, Arte $e$ Zodiaco, 67.

34 See Sesti, The Glorious Constellations, 453.

35 See Sesti, The Glorious Constellations, 374.
} 
constellation of Libra, a brilliant star inside the pair of scales forms an irradiation that, with the balance between the scales, reflects light and dark luminosity during the rotating planetary cycle. The constellation of Libra with its shining aspects connects with the resplendent aspects of Venus. The shape of the scales as a balanced pair and their association with the balancing effects of light and darkness traditionally refer to the concept of justice as an aspect of Venus's governance. ${ }^{36}$

The notation at the top left of the cartoon, in bold black ink, reads: "Holden, Esq," referring to the name of the patron. This was probably added by the artisans of the Morris Firm for guidance when transferring the cartoon onto a glass panel. Other annotations in charcoal include Burne-Jones remarking: "O! bother then get the inscription better-the CA in first line" (see Figure 2b). The artist is indicating the need to center some of the letters in the scroll. At the top left side of the cartoon are depictions of small arched triangles similar to the Tudor shape of the cartoons. Inside these triangles are the names of the planets. It is hard to identify them because of the time-worn cartoon, but what is legible indicates the order in which Burne-Jones planned his work schedule or the window design. From left to right we read: Planet, Jupiter, Mars, Venus (with a long arrow pointing down to the figure of Venus), Apollo (with a depiction on a radiating sun), Earth, and maybe Moon (difficult to read the notation; see Figure 2c). The last two areas are illegible. This type of order in listing the planets also appeared in the Apollo cartoon. Perhaps this list relates to Burne-Jones's planned placement of the Planets cycle as glass panels in the Music Room, and it may also provide an interpretation about the function of the room and the visual association between music and the sound of the planets.

\section{The Planet Luna (Moon) Stella Mutabilis Lunae}

Throughout his artistic career, Burne-Jones composed several images depicting the Moon. His earliest known composition was created during his travels in Italy in 1871 (see Figure 16). In the painting, Burne-Jones depicted a creative image of the Moon hiding from the Sun's rays. In a firmament studded with blue stars, a female figure, Luna (the Moon), rides on a globe. While the tresses of her hair have been turned golden by the Sun's radiation, Luna employs her attire to hide from the Sun's reflections. Her face is veiled with the sleeves of the dress, and folds of her train cover the circular form of her planet, leaving only a small crescent ridge visible. In this composition, Burne-Jones experimented with a variation of tonalities employing only the color blue, thus forming an orchestral symphony of blue tones. ${ }^{37}$ Perhaps Burne-Jones was influenced by his fellow artist James Abbott McNeill Whistler's paintings on nocturnes and symphonies, e.g., Nocturne: Blue and Silver-Chelsea of 1871 at the Tate Gallery in London. ${ }^{38}$ Burne-Jones's curved lines in the design of the figure, the globe, and the crescent moon evoke a rotary movement, alluding to lunar oscillations in the sphere, while the reflections of the sky and the water produce an eerie atmosphere. Inventively, Burne-Jones interspersed bright light effects, showing how Luna hides from the bright sunlight and demonstrating the astral connection and rivalry between the sun and the moon; between day and night; and between light and dark effects. The overall luminosity of the blue light and its reflections augment Burne-Jones's understanding of the Moon's coloration. Luna's ancient Roman name lumina signifies light or “to illuminate.” In the painting, Burne-Jones conflated the meaning of lumina: physically, alluding to illumination of a visible area as the Moon, which

\footnotetext{
${ }^{36}$ See Chevalier and Gheerbrant, A Dictionary of Symbols, 829; and Zuffi and Novellone, Arte e Zodiaco, 113. Venus's association with justice is based on the myth of Amor and Psyche.

37 See W. Stirling, The Canon: The Pagan Mystery as the Rule of all the Arts (Glastonbury, UK: The Lost Library, 1897), 262, who notes that Pythagoras, "using the term of music, called the interval between the earth and the moon, a Tone."

${ }^{38}$ For the image, see from http://www.tate.org.uk/art/artworks/whistler-nocturne-blue-and-silver-chelsea-t01571.
} 
radiates at night; and metaphysically, referring to Luna as the astral planet that illuminates not only through shining stars but also through its mysterious bluish coloration, which evokes a mystical atmosphere for the imagination and the intellect of a creative mind.

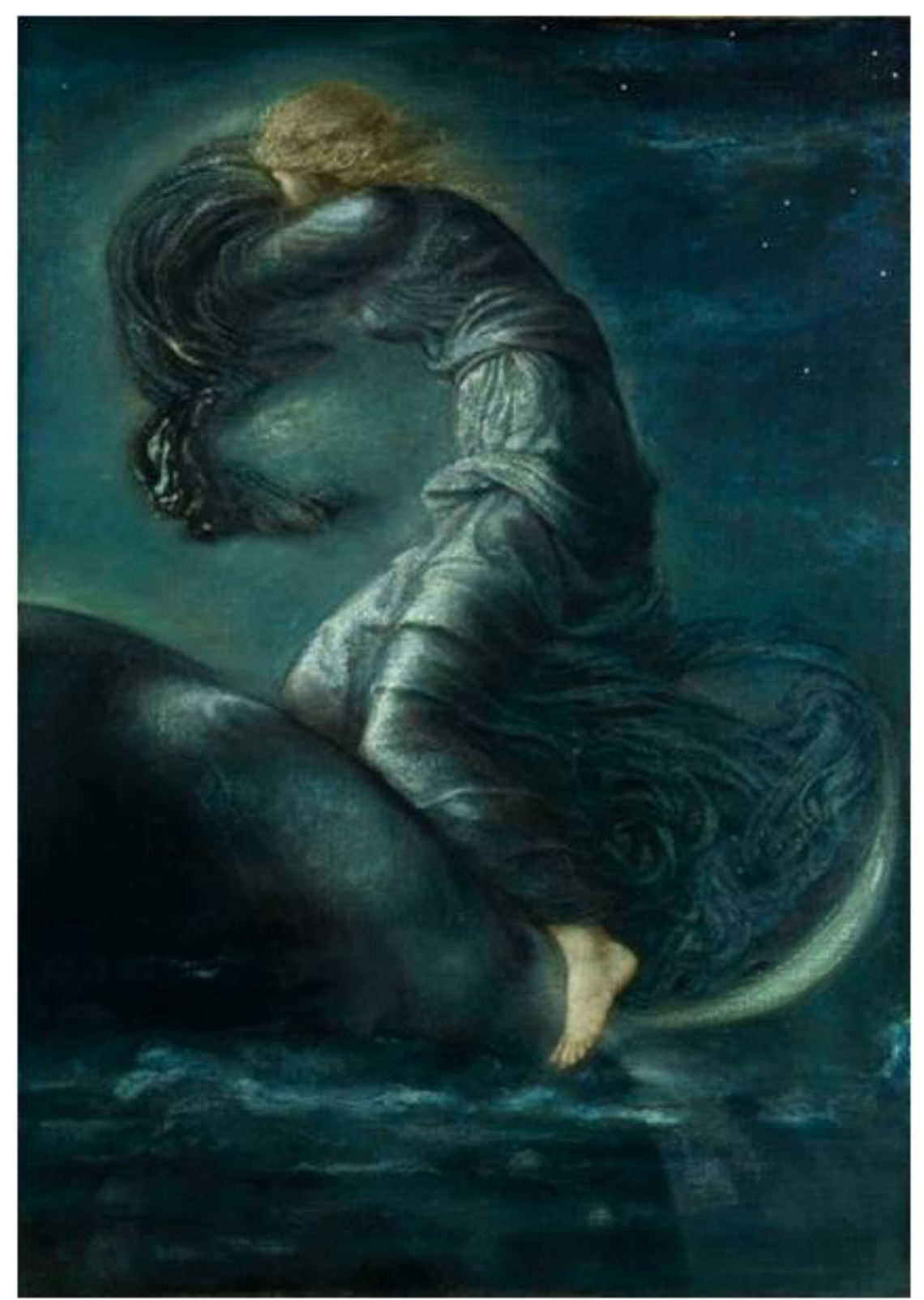

Figure 16. Edward Burne-Jones, Luna (Moon), 1871-72. Oil on Canvas. Photo credit: CHRISTIE'S IMAGES LTD. 2017. 


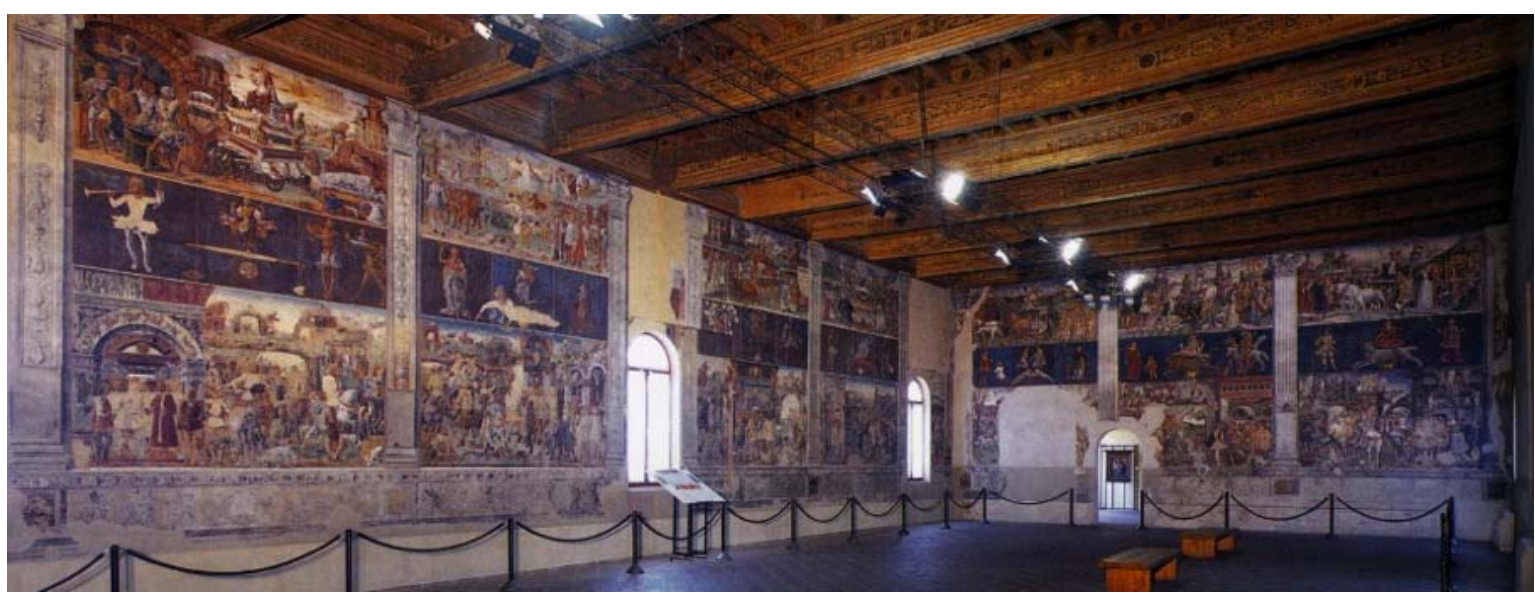

Figure 17. Francesco Cossa and Cosmé Tura, Hall of the Months, 1470-1484. Palazzo Schifanoia, Ferrara.

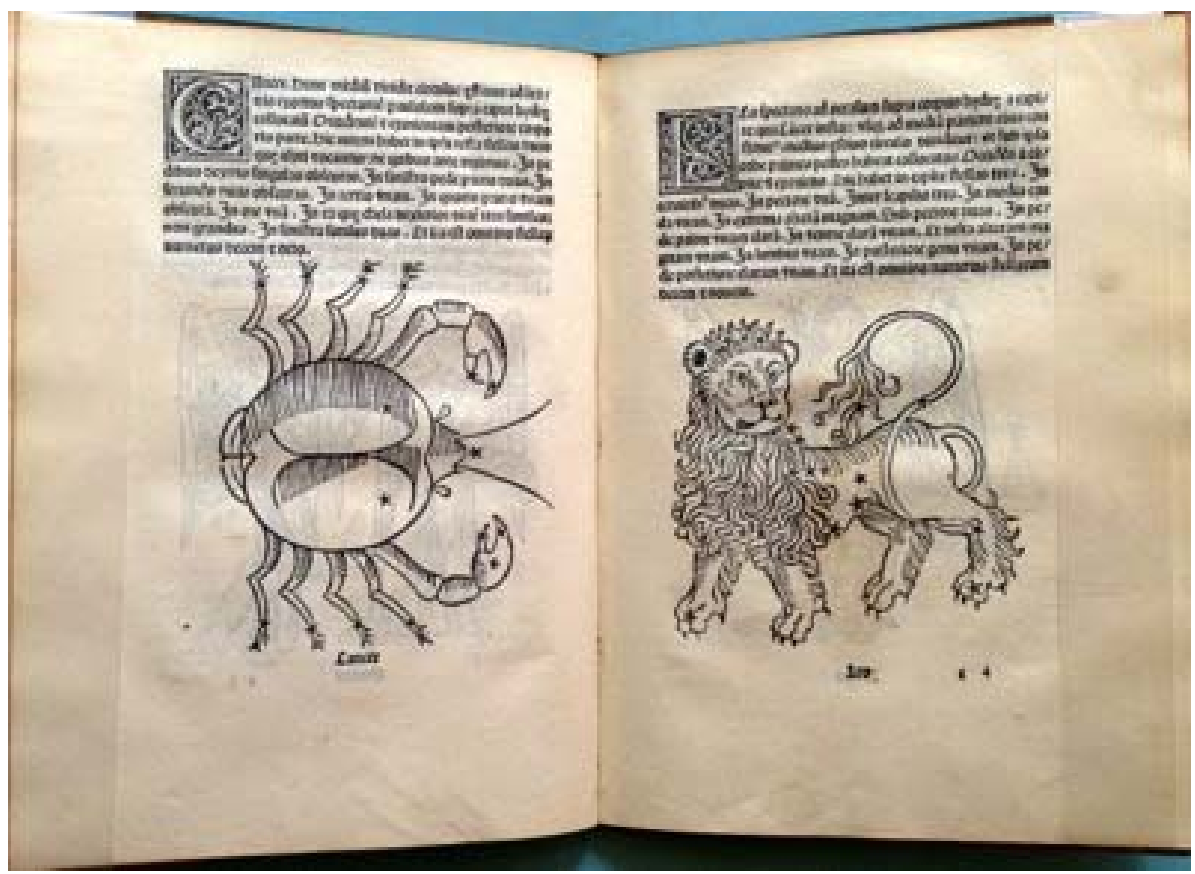

Figure 18. Hyginus, Poeticon Astronomicon, det., 2nd Century CE, published in Ferrara in 1475, without illustrations and in Venice in 1482 with illustrations.

The compositional design for the Luna cartoon, like those for the other planets, is in arch-shape format (see Figure 3). The figure's halo identifies her as a goddess or astral being. Luna is beautifully dressed in classical attire with a "wet drapery" motif that recalls Burne-Jones's admiration for the Greek sculptor Phidias (480 BCE-430 BCE), whose marble statues for the frieze and pedimental area of the Parthenon were (and are) in view at the British Museum during Burne-Jones's numerous visits. Burne-Jones depicted Luna as a seated female navigating through the sea in an ancient Roman boat. ${ }^{39}$ Holding aloft with her left hand a crescent moon, which acts as rudder of her celestial ship, Luna intensely watches the nautical direction of her physical

${ }^{39}$ See Mulryan, Vincenzo Cartari, 92, for the boat is associated with the ship of Isis, the Egyptian Goddess, who navigated through the sea. 
and metaphysical realms. ${ }^{40}$ With her right hand, Luna holds fast to the edge of the boat, adjusting to the physical movements of the sea waves. In the cartoon, Burne-Jones has skillfully contrasted the astral deity's beautiful hands with tapered fingers and the crab's clumsy regenerative claws, alluding to the way in which both the moon and the crab adapt to atmospheric and climatic changes during oscillatory movements.

Astrologically, Luna rules the sign or constellation of Cancer, which is depicted by the zodiac sign of the crab, a creature associated with water and movement. ${ }^{41}$ Burne-Jones depicted a crab surfacing from the sea and following the boat's navigation. The movement of the boat together with the crab's oscillation alludes to the Moon's monthly cycle, and the crab being part of the constellation of Cancer alludes to the seasonal summer (July and August).

A shower of stars decorates the celestial background, and a large scroll with a Latin inscription reminds the viewer about the mutable astral Moon, Stella Mutabilis Lunae. ${ }^{42}$ The mutable qualities of the Moon correlate with the cycles of the sea, as the cartoon notes through its use of blue tonalities and reflections of the sky in the water. In antiquity the sound of the planets was said to parallel the sound of music. ${ }^{43}$ The planets composed a musical sphere. In Burne-Jones's cartoon of Luna, we can imagine that the sound of the moon parallels the sound of the waves. Burne-Jones created a physical and metaphysical bond among art, astronomy, and music. Luna is an image of a poetical, planetary symphony.

\section{Morning Star (Stella Matutina) and Evening Star (Stella Vespertina)}

Both stars are associated with Venus's planetary configuration. They represent the early morning light and the late evening light. The cartoon of Morning Star (Stella Matutina) is located at Lady Margaret Hall in Oxford (see Figure 4), ${ }^{44}$ and Evening Star (Stella Vespertina) is displayed at the Torre Abby Museum (see Figure 5). There are two respective pencil-on-paper drawings on the subject in the drawing collection at the Birmingham Museum and Art Gallery. ${ }^{45}$

The Latin inscriptions, Stella Matutina (Morning Star) and Stella Vespertina (Evening Star), are located in

\footnotetext{
${ }^{40}$ In the arrangement of this composition (waves, boat, crab and Luna holding on to a crescent moon), Burne-Jones recalled the imagery of Filippo Calendario's The Reign of Cancer with the Moon, a fourteenth-century Venetian marble sculpture from a capital in the Palazzo Ducale, which Burne-Jones probably saw during his many visits to Venice.

41 See Sesti, The Glorious Constellations, 267-271; and Zuffi and Novellone, Arte e Zodiaco, 83-90.

42 See Archives at the Torre Abbey Museum, Accession Number A.113. The drawing is made of charcoal and colored chalks, blues and gold and violets. The drawing was restored and cleaned in 1988 by the Bristol City Art Gallery. The Catalogue of Designs entry of July 1870 names Fletcher as the glass painter who composed the panel (2512/35 and 2477/36).

${ }^{43}$ See Godwin, Harmony of the Spheres, 282, 442-444; James, The Music of the Spheres, Introduction; and Lachièze-Rey and Luminet, Figures du Ciel, 58-62.

${ }^{44}$ I am grateful for the assistance of Reverend Dr. Allan Doig, Fellow and Chaplain, Lady Margaret Hall, Oxford, who confirmed in an email of 4 January 2015 that they lack the glass panel but still have Burne-Jones's cartoon, as indicated by the image reproduced here. The Rev. Doig and his assistants Joshua Goldman and Alastair Person provided me with a photograph and documentation on this cartoon. According to a record and catalogue from Lady Margaret Hall at Oxford: "Edward Burne-Jones's Stella Matutina, in grey and blue chalk on paper was located in Grier's flat after her death as being in the 'Back Bedroom'.” In the inventory of items from Lady Margaret Hall, there is a specific notation by Principal Grier referring to Burne-Jones's cartoon as "that will probably be wanted by the Hall." Mary Lynda Dorothea Grier (1880-1967) was a British educational administrator and a Principal of Lady Margaret Hall in Oxford between 1921 and 1945. She also was an economist and an art collector. See British Library Manuscript Collection MS65258 and Oxford University Lady Margaret Hall Collection MS NRA-11605, for information about the art collection

${ }^{45}$ In 1952, Mrs. Angela Thirkell gifted these drawings to the Birmingham Museum and Art Gallery. Their accession numbers are 1852P4.14 for Morning Star and 1952P4. 13 for Evening Star. For the images, see http://www.bmagic.org.uk/-objects/-

1952P4.14/images/143868, and http://www.bmagic.org.uk/objects/1952P4.13/images/143862. Burne-Jones also completed in oils two other versions of Evening Star in 1870, now in a private collection, and in 1872, in the Collection of Lord Lloyd-Webber. These small paintings differ in compositional design and coloration from the drawings and cartoons. In these versions, Burne-Jones composed a solo angelic figure floating in a celestial atmosphere above a terrestrial land.
} 
an arch-shaped design, just above the head of these astral stars. The Stella Matutina refers to a bright and clear light of day, its start, and an early sunrise. Seated on a few floating clouds, a beautiful young female focuses on the light at the horizon. She is awakening to a brilliant spectacle of the first light of day, as she raises her arm to partially cover her eyes and to partially gaze at the brilliance of the sunrise. Her smiling face expresses hope for the coming of the new light of the day. Below the clouds upon which she sits, a dormant costal area merges into a placid blue sea. The cartoon is of pale cream coloration with blue tints. The woman is fully draped in a classical garment and portrays Morning Star. ${ }^{46}$ Burne-Jones's treatment of all'antica attire in both Morning Star and Evening Star resembles that of Luna in that it recalls the drapery treatment of Phidias's Deities of 438 BCE in the right side of the East Pediment of the Parthenon at the British Museum. His female type, crossed leg, and arm poses are appropriations from Michelangelo's Erythraean and Delphic Sibyls of 1510 on the Sistine Ceiling at the Vatican. ${ }^{47}$ Burne-Jones was a frequent visitor to the British Museum and Italian museums, often composing drawings after seeing works in their collections. ${ }^{48}$ In Morning and Evening Star cartoons, Burne-Jones has paired off these two opposite astral lights.

The Stella Vespertina refers to the luminous star of Vesperus that appears at sunset when the Planet Venus rises. The overall tonality of the design is of blue and purple coloration. Vesperus, a young female dressed in classical garments, has fallen asleep while floating on clouds in the dark sky. She gently rests her head with long, curly tresses on a bent arm, which is supported by clouds. With this composition, Burne-Jones pays also homage to Michelangelo's Night of 1524 in the Medici Chapel, New Sacristy in San Lorenzo in Florence. The other arm lies on her elaborately draped lap. Her dangling crossed leg directs attention to an area below, where a landscape representing large hills on the right, a coastal shore in front, and extensive rippling of the sea suggest the effect of astral lunar motions on earth. One of the inlets depicts a small castle or a temple in a dark background, further suggesting that night has fallen on the terrestrial world as well.

\section{The Planet Saturn, Saturn Pallidum Sidus}

Within the traditional Tudor arch, Burne-Jones introduces the planet Saturn (see Figure 6). An aging man wrapped in classical drapery is seated on a cloud. His coronet is a composed of a large nimbus, while his crown is decorated with small tablets containing stars. His long hair merges with his long, wavy beard. Burne-Jones composed a Mosaic figure recalling Michelangelo's painted prophets from the Sistine Ceiling, Jeremiah and Isaiah of 1510, and sculpture of Moses of 1513 at San Pietro in Vincoli in Rome. Unlike all the discalced figures from the Planets cycle, Saturn wears sandals. He holds in his right arm a tall scythe, associated with his harvesting power, while a winged serpent coils around his left arm. Two twin nude putti, similar to those in Earth and the Seasons cycles, rest at Saturn's feet. They are also floating on clouds. At the top, on the left side of the composition, a kouros [water-carrier] carries two large vessels and is pouring water from heaven to earth. There is an interesting notation written by Burne-Jones as an instruction to the glass artisan: "Not - any rain here" (i.e., "remove the raindrops"). The section just above the putti is filled with water dripping from the kouros's vessel, suggesting rain. In the written comment Burne-Jones observed that "the extra rain" was out of balance with the starry composition on the opposite side: large falling stars are scattered throughout the

\footnotetext{
${ }^{46}$ Burne-Jones completed several drawings on clouds. See Mrs. Angela Thirkell's gift to the Birmingham Museum and Art Gallery, Accession Number 1952P6.2. For the image, see from http://www.bmagic.org.uk/objects/1952P6.2/images/143877.

47 A drawing of Evening Star (Stella Vespertina) is found in one of Burne-Jones's sketchbooks in the Birmingham collection (1952 P4.13), which forms part of Morris and Company Windows Book (1940P601.1), number 346.

${ }^{48}$ See GBJ Memorials, 2:21, 279.
} 
composition. Below, in the foreground, a sea area meets a coastal rock formation with a stepped architecture, reminiscent of the structure of a Mesopotamian ziggurat.

At the top of the composition, a large scroll with the Latin inscription Saturn Pallidum Sidus refers to a silver jubilee as well as to the planet's silvery white color. The overall coloration of the cartoon is of a grey tint, which is an artistic expression of the inscription itself (palladium being a chemical metal of silvery-white, resembling platinum — discovered in 1803 by the English physicist William Hyde Wollaston [1782-1828]). The scroll wraps around an interesting architectural building. In its lower section, a post lintel wall is pierced with pilasters, reminiscent of the first Hebraic Holy Temple, the Temple of Solomon before Nebuchadnezzar destroyed it in 587 BCE (2 Chron. 3: 1). Burne-Jones designed an eclectic architectural structure. Saturn's halo against the building forms a semicircular arch for the entrance to the temple. Above the scroll, the roof terminates in the shape of a curved dome with scaled designs, an allusion to the Roman Pantheon. Two visible large Doric capitals support the domical structure.

Burne-Jones continued to compose an unusual set of zodiac signs. The water-bearer, the zodiac sign for the house of Aquarius, is placed inside a triangular space formed by Saturn's large blade and the scythe's handle. ${ }^{49}$ Saturn rules the house of Aquarius. But Burne-Jones portrays a winged serpent coiling around Saturn's arm. According to Ptolemy, the constellation of Ophiuchus and the Serpent was composed by "Ophiuchus (a Greek word meaning the Man Who Holds the Serpent) holding a large serpent around him." Ptolemy considered Saturn to have the same nature as Ophiuchus. ${ }^{50}$ Burne-Jones here is conflating Ptolemy's constellation with his Saturn's conceit. The same perplexity is encountered with the depiction of the nude twin putti. If the aging Saturn is understood to represent the ancient God Zeus, then the twins represent Castor and Pollux (Dioscuri), the sons of Zeus. They partake of the constellation of Gemini, as noted in Johannes Hevelius's Uranographia totum caelum stellatun. ${ }^{51}$ Hence Burne-Jones's Saturn is ruling the house and constellations of Aquarius, Gemini, and Ophiuchus and the Serpent.

\section{The Planet Mars, Mars Terreus}

Burne-Jones continued with the conception of Mars from the drawing of Winter from the Seasons cycle, but with some symbolic changes (compare Figures 7 and 15). The cartoon is unfinished because, after working the drawing for the cartoon, Burne-Jones started to touch it up with watercolors. Mars, the red planet often represented by the alchemical symbol for iron, rules the houses of Scorpio and Aries. ${ }^{52}$ Burne-Jones depicted the dual nature of Mars with two instruments of war: the shield, a symbol of protection and passivity; and the lance or sword, a symbol of aggression and action. Both symbols of defense, the circle (shield) and the arrow (lance) form the symbol of Mars or glyph $\hat{\jmath}$.

\footnotetext{
49 See Sesti, The Glorious Constellations, 225; and Zuffi and Novellone, Arte e Zodiaco, 1151-1152.

${ }^{50}$ See Sesti, The Glorious Constellations, 395; or this may refer to the legend that Saturn began his journey at midnight in a chariot led by serpents, hence rendering the snake as a sacred reptile, as represented in Hyginus's Poeticon Astronomicon (Venice: Enhard Ratdolt, 1482), Allegory of Saturn. For the woodcut image, see https:/www.granger.com/resultsasp? inline $=$ true \&image $=0014554 \& w w w f l a g=4 \&$ item $x=54 \&$ screenwidth $=1384$.

51 Johannes Hevelius, Uranographia totum caelum stellatun (Gdansk, 1690); see Sesti, The Glorious Constellations, 344. Johannes Hevelius was a German astronomer who corresponded with the English astronomer Edmund Halley, who first calculated the orbit of a comet in 1678 and was a friend of Isaac Newton.

52 See Sesti, The Glorious Constellations, 443; Zuffi and Novellone, Arte e Zodiaco, 119-120; and R. Hinckley Allen, Star Names: Their Lore and Meanings (Glastonbury, UK: The Lost Library, 1899), 360-364.
} 

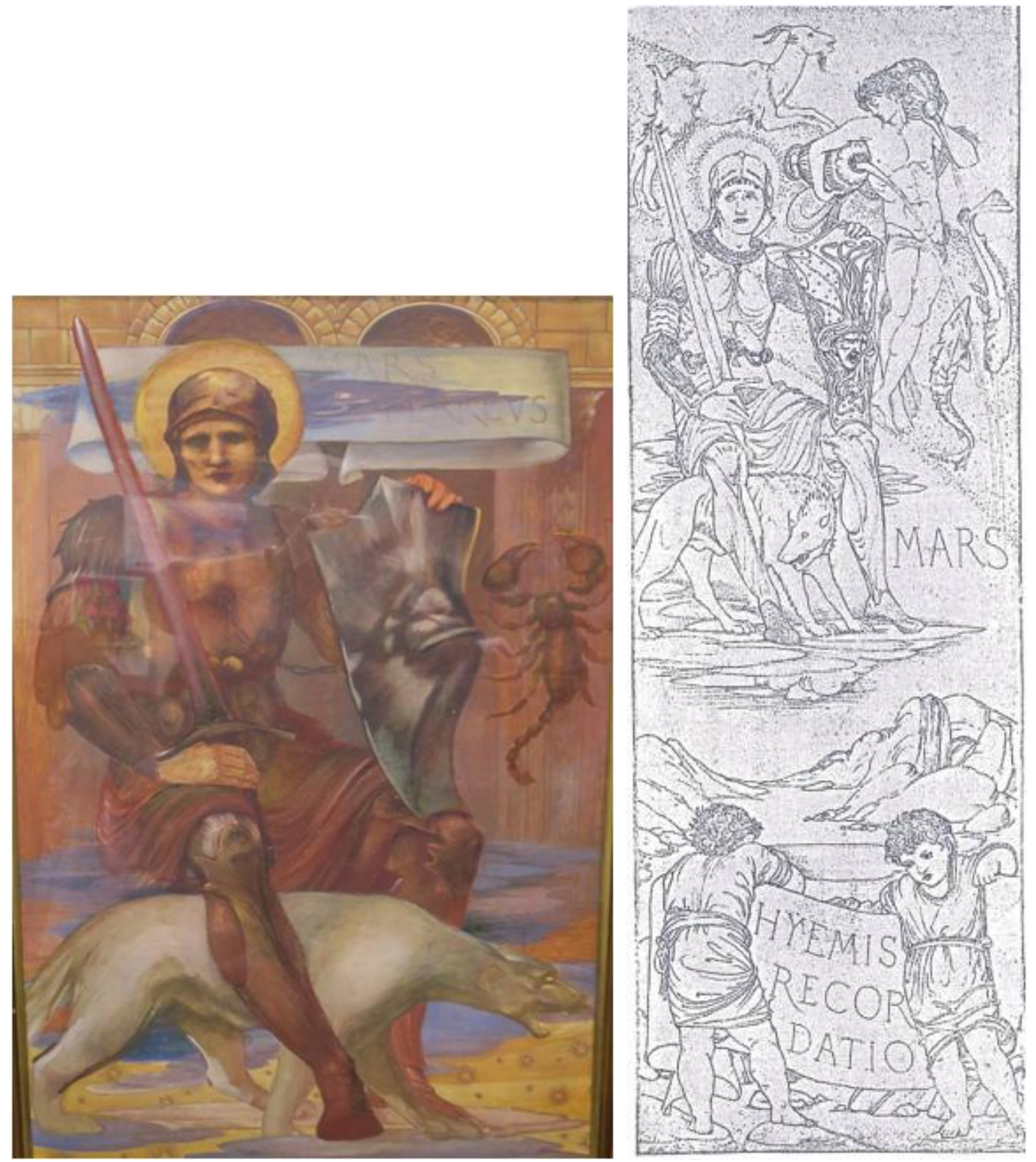

Figure 7. Edward Burne-Jones, Mars (Mars Terreus), 1879,

Figure 15. Edward Burne-Jones, Winter (Mars), 1868.

cartoon.

A few comparative observations between Mars representing Winter in the Seasons cycle and the cartoon of Mars demonstrate Burne-Jones's appropriations and transformations of conceits (see Figures 7-15). In the cartoon, for a zodiac sign of Mars, Burne-Jones selected a large scorpion crawling along the palace or temple walls, which is not included in the Winter's imagery. He also replaced the traditional tame ram, a symbol of Aries, with a fierce feline, perhaps a puma or lynx, in contrast to the wolf that accompanied Mars in the 
Winter. ${ }^{53}$ In both compositions, Mars' head is surrounded with a golden nimbus, an allusion to his planetary sovereignty. He is dressed as a medieval knight, wearing a helmet in the shape of a lion's head, a symbol of fortitude and valor. He holds an upright sword, which is resting on one leg, while holding on the other leg a shield decorated with a lion's head, in contrast to the Medusa's head seen in the drawing for Winter. The depiction of the Medusa's head in the Winter's shield connects Mars with the myth of Perseus, where this semi-god liberates enchained Andromeda by showing the head of the Medusa to the Dragon that kept her prisoner. In the firmament, the placement of the constellations Perseus, Andromeda, and Dragon (Draco) are in close astral conjunction. In the cartoon, Burne-Jones changed the imagery in Mars's shield, preferring a lion's head instead of a Medusa's head. But in both conceptions, the artist connected the astral influence to mythological and constellation allusions. Visualizing the volatile aspects of the planet Mars, the Roman God of War, Burne-Jones tinted the cartoon with strong reddish tonalities, ${ }^{54}$ as indicated by the Latin inscription Mars Terreus (The Soil of Mars). But Burne-Jones also alluded to the positive qualities imparted by this planet - assertiveness and fearlessness - indicated by the sword at rest and the shield attached by a chain to the center of the cuirass. These also suggest that Mars's belligerent desire toward war can be controlled with the passion of his heart, achieving peace through love.

Unlike the starry, celestial backgrounds of other cartoons in the Planets cycle, an architectural construction backs Mars in this cartoon. The walls are decorated with pilasters with oak-leaf shafts and acanthus capitals. An arched portal composed of bricks provides a gateway to an unknown palace or temple. ${ }^{55}$ The double-round arches probably refer to the Temple of Janus or Temple of Peace at Argiletum, which consisted of two gates protecting a cult statue of Janus inside the temple. ${ }^{56}$ Mars, the Roman God of War, promised to protect the city of Rome with his heavenly shield; hence the door gates of the temple are closed, because it is a time of peace. Seated on clouds and resting his feet on a golden stellar platform, Mars controls the feline animal between his legs in order to rule his planet with concord and peace. The celestial decorations in the scroll where the Latin inscription is incised reflect a peaceful firmament with bluish and golden tints that harmonize with the golden starry platform below his boots.

\section{The Planet Earth, Terra Omniparens}

Burne-Jones's Latin inscription of Terra $m$ [om] niparens is an abbreviated motto from Titus Lucretius Carus in De rerum natura, Book VI: Terra mater omniparens et alma (producing and all-nourishing mother earth) and from Virgil's Aeneid, Book V. Burne-Jones employed this phrase for the first time in the decoration of the cover for the pianoforte of William Graham (1817-1885), a Scottish merchant of wine, a cotton

\footnotetext{
53 See Julia Cresswell, Legendary Beasts of Britain (Oxford: Shire Library, 2013), 24. These wild cats were seen in Invernesshire. Associating Mars with the puma, a local feline animal, rather than with the traditional ram parallels the association of Scorpio with the animal scorpion, an allusion to strong emotion and reaction.

54 See Mulryan, Vincenzo Cartari, 310-322, for discussion on Cartari's conception of Mars' birth and violent nature.

55 Burne-Jones executed numerous architectural drawings of arches, doors, and gates, presently housed in the drawing collection of the Birmingham Museum and Art Gallery. See in particular Mrs. Angela Thirkell's gift, Accession Number 1952P6.23. For the image, see fromhttp://www.bmagic.org.uk/objects/1952P6.23/images/143898.

${ }^{56}$ See Titus Livius (Livy), History of Rome, B. O. Foster (Trans.), 2 vols. (Cambridge, MA: Harvard University Press; Loeb Classical Library, 1919), 1: 19; and James C. Anderson, "Domitian, The Argiletum and the Temple of Peace," American Journal of Archeology 86, no. 1 (January 1982): 101-110.
} 
manufacturer, and an art collector. ${ }^{57}$

The arched-frame design of Earth is bolded, as in the cartoons of Venus, Sun (Apollo), and Jupiter. In the depiction of the planet Earth, Burne-Jones focused on the natural aspects of the planet, but always alluding to the astral connections through the depiction of the constellations (see Figure 8). The cartoon of Earth comprises complex astral and terrestrial symbolism. Traditional allusions focus on Earth as the "mother" of nature. ${ }^{58}$ Earth resides in a natural setting, an earthly paradise. As a mother associated with nature and seasonal transformations from fall and winter to spring and summer, Earth is equated in mythology to ancient fertility goddesses, in Greece with Gaia or Ge and in Rome with Terra or Tellus, as well as to the goddess of agriculture, Demeter (Greek) or Ceres (Roman). Planet Earth is symbolically surrounded by the four elements of nature — air, water, fire, and earth—alluding to her nurturing terrestrial life.

With her right hand, Earth pours heavenly water obtained from the clouds to irrigate and cultivate the land and maintain the flowing rivers. Burne-Jones has transformed the floating stars depicted in the other cartoons of planets into visible water bubbles floating from the celestial vessel. By contrast, Earth's left hand plants an oak tree on earth. Burne-Jones composed a background for the scene of a thick forest populated by a variety of fig, laurel, and oak trees, while the foreground is filled with the foliage of hibiscus flowers and iris. The personification of Earth is seated on top of a hill. The maiden figure or kore is dressed all'antica, again recalling the classical figures of Phidias's Deities at the British Museum and portrayed in the image of his beloved muse, the Greek sculptress Maria Cassavetti Zambaco. ${ }^{59}$ This is the only planetary figure lacking a crown. Earth's long, curvy tresses parallel the branches of the trees, while her garment is decorated with a necklace composed of willow leaves and her dress-belt is formed with ivy leaves. Both of these evergreen plants refer to Earth's permanent powers of fertility. ${ }^{60}$ Other symbols of cyclical fertility, transformation, and growth in nature include the depiction of a nude child resting at her feet and a snake emerging from the hibiscus

${ }^{57}$ In 1879, Burne-Jones was commissioned to decorate the cover of a pianoforte for Graham's daughter, Frances, for her birthday. See Theodore Chilb, "On the Decorations of Pianos," in Early Journal Content (1883): 167, for a description of Burne-Jones's cover decoration of a pianoforte:

Earth, Terra omniparens, is the universal mother, sits enthroned amidst strange arabesques of vine leaves and trailing vines, the leaves of pale green, the vines of greenish blue, the whole on a background of pale blue clouds edged with gold. In the lap of mother earth are cherubs sleeping, while some twenty other chubby cherubs are clambering amongst the vine leaves and branches.

See also Wildman and Christian, Edward Burne-Jones, 275-277, for a discussion of the other decorations on the pianoforte.

58 A small encaustic painting of Burne-Jones's Mother Earth is presently found at the Worcester Art Museum, MA. The title to this painting was given to the work when first exhibited at Villa von Stück in Germany in 1974. See Worcester Art Museum Archives. I am grateful to Debby Aframe, Librarian of the Worcester Art Museum, and James Welu, former Director and Museum Curator of the Worcester Art Museum, for access to their archival data, suggestions, and invitation to lecture on "Edward Burne-Jones's Terra (Earth Mother) on 16 January 2016 at the museum.

59 See a drawing of her as Traditional Greek Costume of 1867 at Birmingham Museums and Art Gallery (Accession Number 1904P216). For image, see http://www.bmagic.org.uk/objects/1904P216. See also Elisa Korb with John Christian and Tessa Sidey, Hidden Burne-Jones, Works on paper by Edward Burne-Jones from Birmingham Museums and Art Gallery (London: Dan Giles, 2007), 54; and Fitzgerald, Edward Burne-Jones, 114-115, 119, 147, for an undated letter to F.S. Ellis in which Burne-Jones praised Maria Zambaco's art. For Burne-Jones's depictions of Zambaco, see Liana De Girolami Cheney, "Burne-Jones: Mannerist in an Age of Modernism," in Pre-Raphaelite Art in its European Context, ed. Susan Casteras and Alicia Faxon (New Haven: Associated University Press, 1995), 103-16; and Liana De Girolami, "Edward Burne-Jones' Cupid and Psyche: The Enchantment of an Ancient Tale," in Wege zum Mythos, ed. Gerlinde Huber-Rebenich and Luba Fredman (Berlin: University of Mannheim, 2000), 57-71.

${ }^{60}$ Burne-Jones is also inspired by the theme of the Wood Nymph. Later in his life he completed numerous images with this theme, as collected in the photogravure folio signed by his son Philip, now at the Birmingham Museum and Art Gallery, UK. See in particular image AN: 1900P77, Wood Nymph, which depicts a young woman who resides inside a blooming green tree. 
plant, referring to the serpent's growth through the process of shedding the skin, similar to a child's development into an adult.

Unlike the other planet cartoons, where the zodiac signs and constellation depictions are clearly demarcated, in the cartoon of Earth, their inclusions are less evident and problematic in their conceptions. Since the time of the Babylonians, a young maiden carrying a twig or a rod has portrayed the constellation of Virgo; this attribute explains the origin of the name. ${ }^{61}$ The Latin word virgo is derived from the word virga, meaning young shoot or twig, an association with harvesting and with Demeter or Ceres. The cartoon of planet Earth represents a young maiden rooting an oak tree on earth or holding onto a plant, paralleling Virgo's action. ${ }^{62}$ Hence the constellation of Virgo or the Maiden of the Wheat Fields is associated with the classical cult of the deities of agriculture, in turn connecting with the planet Earth. ${ }^{63}$ Earth's feminine quality as a young woman with unbound hair and crossed legs alludes also to the traditional symbolism of an unmarried female, a maiden or a virgo. ${ }^{64}$

The other unusual aspect of this composition is the young child embracing a dog or a wolf-type. This type of child is similar to Burne-Jones's earlier composition of a putto or putti in representations of Venus's children, Charity, or the Seasons cycle. ${ }^{65}$ Conventionally, the portrayal of a child with a wolf is associated with Mars's sacred animal, the wolf or lupus, which symbolizes protection, assertion, or instinct. But it is also associated with the Roman legend of Romulus and Remus, who were nursed by a lupa [she-wolf]; and Celtic mythology associates the wolf with fertility and countryside. ${ }^{66}$ Both traditions refer to the nurturing nature of the wolf.

In the decoration of the side walls of Graham's pianoforte, Burne-Jones included several medallions with the story of Orpheus, who was known for his music that enchanted the animals of the underworld. For this topic Burne-Jones completed numerous drawings, among them Cerberus of 1875 at the Ashmolean Museum in Oxford, depicting a type of dog-wolf similar to the one in the Planets Earth cartoon. The dog-wolf is noted in the constellations as Canis Lupus, called also Dog Sirius or Dog Star. ${ }^{67}$ This bright constellation is seen in our sky especially during the summer months, when it shines intensely. Perhaps this is why Burne-Jones represented the child and the dog-wolf with such wide and brilliant eyes as well as intensely gazing at the viewer - a sharp contrast with the downcast eyes and pensive look of the figure of Earth (Virgo).

In the cartoon of Earth, unlike any of the other planetary cartoons, Burne-Jones demonstrated his interest in and appropriation of the designs for the constellations of Virgo, Canis Lupus, and Aquarius from the very popular constellation playing cards of Rev. Richard Rouse Bloxam's Urania's Mirror or A View of the Heavens,

\footnotetext{
61 See Allen, Star Names, 461-462.

${ }^{62}$ See Allen, Star Names, 461-462; and http://www.constellationsofwords.com/Constellations-/Virgo.html.

63 See Allen, Star Names, 461.

64 See Veda Cobb-Stevens, "Speech, Gesture and Woman's Hair in the Gospel of Luke and First Corinthians," in Liana De Girolami Cheney, ed., The Symbolism of Vanitas in the Arts, Literature, and Music: Comparative and Historical Studies (New York/Ontario: Mellen, 1994), 328, 311-340.

${ }^{65}$ For example, Burne-Jones's Caritas of 1867, a watercolor and gouache with gold paint, in a private collection in London. For the image, see http://paintingandframe.com-/prints/edward_burne_jones_caritas-49275.html. See also Liana De Girolami Cheney, Edward Burne-Jones' Mythical Paintings: The Pygmalion of the Pre-Raphaelites (London: Peter Lang, 2013), 82-102, for representation of children as putti.

${ }^{66}$ See Cooper, An Illustrated Encyclopaedia of Traditional Symbols, 194; Hans Biedermann, Dictionary of Symbolism (New York: Meridian Books, 1994), 387-891; Chevalier and Gheerbrant, A Dictionary of Symbols, 1119-1123; and Allen, Star Names, 278-79.

67 See Allen, Star Names, 117-118.
} 
published by the Royal Astronomical Society in London by Samuel Leigh in $1825 .^{68}$ In 1867 , furthermore, the English astronomer William Huggins (1824-1910), a gold medalist of the Royal Astronomical Society, was the first astronomer to establish celestial radial velocity by measuring the movement of the Dog Sirius Star. Burne-Jones probably knew about these astronomical discoveries and their application, due to his strong interest in the subject.

\section{The Planet Jupiter, Regia Stella Jovis}

In a Tudor arch-shape design, the central image includes a large bearded man crowned and enthroned as a divine and mortal ruler (Figure 9a-b). ${ }^{69}$ A bejeweled cap in the style of the Holy Roman Emperor is composed of a sectioned golden circle; each section contains elaborately inserted precious stones. Around this honorific royal attribute, a starry halo further alludes to the figure's sovereignty. Draped in all'antica imperial attire, with an under-chemise pinned at the neck with an oval-shaped jewel and covered by a large toga, he sits on a throne of clouds. In his right hand he holds a scepter, a ceremonial staff that symbolizes his divine role and authority, and his left hand rests on his lap while holding a thunderbolt, a celestial weapon of lighting. These attributes associate the figure with Jupiter, Ruler of the Gods and Cosmos, as written in the scroll with the Latin inscription Regia Stella Jovis ${ }^{70}$ that names Jupiter as the Regal Star, meaning the ruler of the universe. Jupiter is the King of the Gods and the King of the Heaven and Earth.

In the foreground of the cartoon, beneath Jupiter's feet, a landscape represents a citadel and an extended seascape, thus connecting Jupiter with his terrestrial dominion, while at the top, stars surround the constellation of Sagittarius, alluding to Jupiter's celestial realm. The zodiac sign of Sagittarius is composed of an armed centaur, referring to the heroic centaur Chiron of Greek mythology. ${ }^{71}$ In this cartoon, Burne-Jones composed the lower body of the centaur in the shape of an energetic horse, while the upper part is a human who resembles the young Roman god Cupid. He carries a long bow with his left hand and arrows with his right hand. Although nude, the centaur's upper body is decorated with a wind-blown mantle, whose edges join together to form a necktie in the shape of a lion's paws. This subtle detail refers to the battle between Hercules and the centaurs over serving wine at a meal, where Hercules, whose attribute was the Nemean lion's skin cape, killed Chiron. After his death, the Ruler of the Gods made Chiron into the constellation of Centaurus or Sagittarius.

The overall cartoon is tinted with grey coloration. At top on the left side, in bold black letters, the word Woodlands is in the margin, as in the cartoons for Venus and Apollo. The handwritten inscription on the top right through the perforate edges of the cartoon says "Jupiter" and next to it "Luna." Arrows point to the word Jupiter on the image, identifying for the artisan the planetary deity. In this cartoon, Burne-Jones designed several quick studies on the borders, unseen in the other cartoons. In the left border there is a quick charcoal sketch of a grasping hand, a study for Jupiter's hand holding a staff in the finished imagery. Across the page, close to the right border, there is another rough sketch of a grasping hand, a study for Jupiter holding a thunderbolt. On the top corner on the left side there is a charcoal sketch of two figures, probably an earlier conception for the placement of Sagittarius in relation to Jupiter. In this rough sketch, Burne-Jones placed

\footnotetext{
${ }^{68}$ See n. 86. These astronomical cards were published as star charts after Alexander Jamieson's Celestial Atlas. They were engraved by Sidney Hall and designed by Rev. Richard Rouse Bloxam. The group consisted of thirty-two cards of the constellations including the zodiac signs, which later expanded to seventy-nine constellations.

69 See Mulryan, Vincenzo Cartari, 122, enthroned Jupiter according to Pausanias (6.11.1-2).

70 See Mulryan, Vincenzo Cartari, 112.

71 See Sesti, The Glorious Constellations, 297; and Zuffi and Novellone, Arte e Zodiaco, 29.
} 
Sagittarius behind the seated Jupiter in an action of protection, in contrast with the finished imagery, where Jupiter rules the house of Sagittarius with the zodiac sign of the Centaur.

\section{The Planet Sun (Apollo), Solis Aureus Idus}

The cartoon of the Planet Sun or Apollo is also framed by a large black arch. Burne-Jones conflated the seasonal aspects from the depiction of Apollo as ruler of Spring in the Seasons cycle with Apollo as Phoebus, ruler of the Planets (compare Figures 10 and 12). ${ }^{72}$ The composition is dominated by a large male figure, a beautiful Greek kouros dressed with all'antica garments like a Roman emperor. While seated on clouds and resting his body against a royal lion, he plays a lyre. This godly figure is identified as Apollo because of his coronet with a starry halo, which transforms into an open sunflower (heliotrope), alluding to a radiating sun. Thus Apollo is the Sun God. ${ }^{73}$ The corresponding Latin inscription on the left side of Apollo decrees that the Golden Age is here, Solis Aureus Idus. In addition, Apollo's head is crowned with two layers of evergreen wreaths, symbol of endurance and longevity; laurel leaves, a poetical nod to the ancient god's musical skills; and oak leaves, an allusion to the power of his prophetic judgments.

\footnotetext{
72 See Mulryan, Vincenzo Cartari, 63.

73 See Mulryan, Vincenzo Cartari, 44-46 and 54-55.
} 

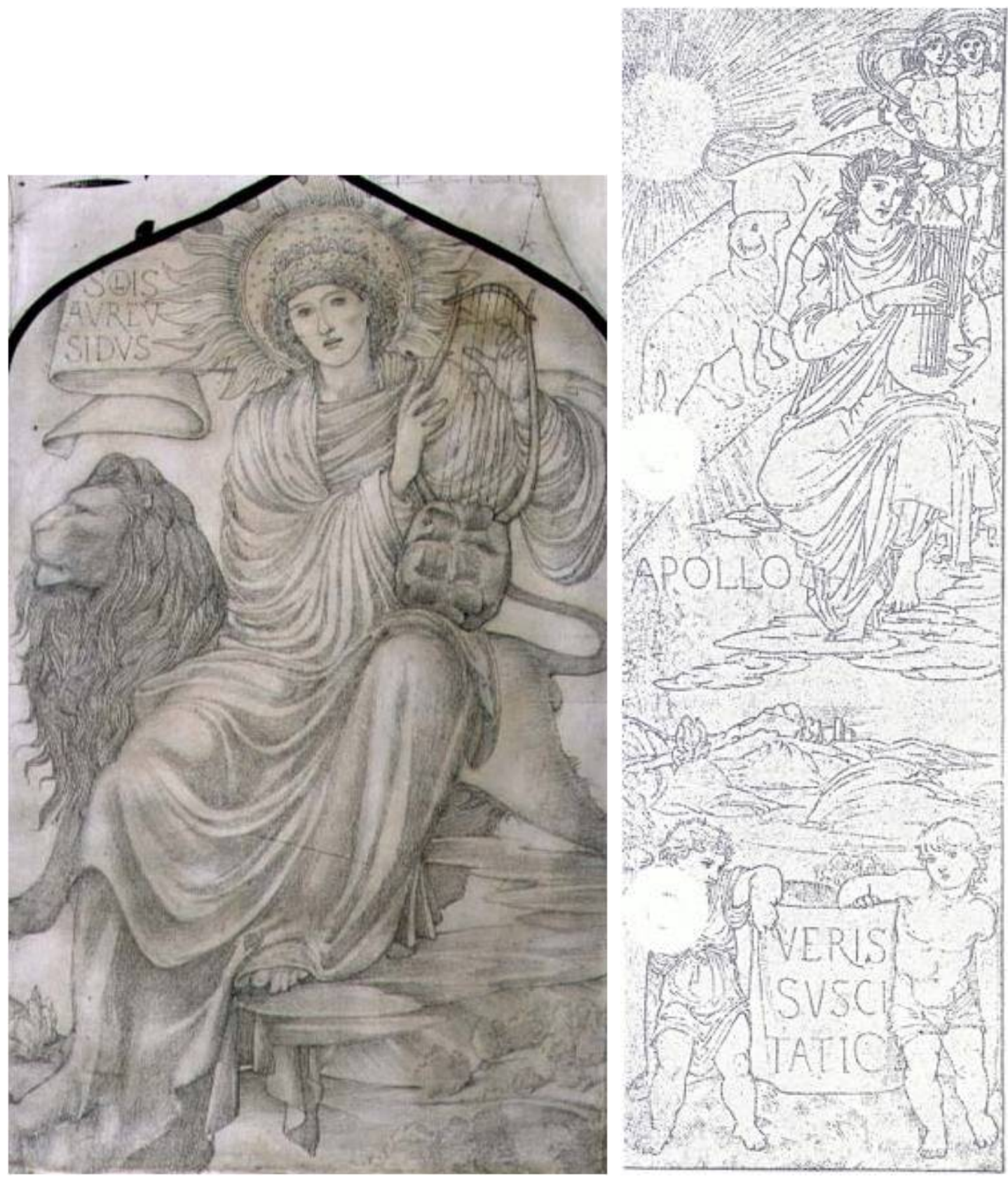

Figure 10. Edward Burne-Jones, Sun (Apollo) (Solis Aureus

Figure 12. Edward Burne-Jones, Spring (Apollo), 1868.

Idus), 1879, cartoon.

Apollo plays a lyre, alluding to the "sweet harmony that the heavens make... [which] originates with the Sun because it is in the middle of the spheres."74 Burne-Jones represented the conceit of the musical instrument in two parts, recalling the ancient myth and contest between Mercury and Apollo where Apollo gained from Mercury his invented instrument, the lyre or chitara (Roman)/kithara (Greek), whose musical sound was similar to the sound made by tapping on a turtle's shell. From classical mythology it is known that Mercury created the body of the lyre from a turtle's shell and its strings from a cow's intestines. Later, Mercury traded

74 See Mulryan, Vincenzo Cartari, 45. 
the musical instrument with Apollo, who in turn donated the lyre to Orpheus, hence the association of all three of these mythological figures with the lyre. ${ }^{75}$ In the cartoon, the musical box in Apollo's lyre is designed in the shape of a tortoise shell, while the string section of seven strings resembles an Italian lira da braccio. The top of the lyre is reminiscent of the shape of Lyra's constellation. The lyre as a musical instrument becomes associated with the constellation of Lyra, recalling the tragic fate of Orpheus, the great musician, when travelling to the Underworld. Hence Burne-Jones included in this planetary cartoon not only the constellation Lyra but also the constellation of Leo.

Apollo, the Sun God, also rules the house of Leo, associated with the constellation of Leo and represented by the zodiac sign of the lion. In the planetary cartoon, seated Apollo rests his body against a royal lion, which alludes to two astral aspects. One is associated with astrology, as the zodiac sign of the lion indicates that Apollo rules the house of Leo. The second aspect is connected with the constellation of Leo and mythological heroes, as in the story of Hercules's twelve labors, in particular Heracles or Hercules's labor of killing the Nemean lion. ${ }^{76}$ There is a discrepancy between the seasonal representation in the Seasons cycle's drawing and the Planets cycle's cartoon: in the Planets cartoon the sign of Leo alludes to a summer month, August (Burne-Jones's birth month), and not to Spring as in the Seasons cycle (Figures 10 and 14). ${ }^{77}$ The imagery of the landscape in the Apollo cartoon represents a warm summer month, with radiating sunlight and extensive fields of blooming vegetation, in contrast to the drawing of Spring of the Seasons cycle, which portrays a citadel in a hilly landscape and a complex zodiacal band containing the houses of Aries (ram), Taurus (bull), and Gemini (twins) also ruled by Apollo.

The overall tonality of the cartoon is grey and gold. The notation at top left in bold letters says "Holden, Esq." Burne-Jones also made notations in pencil at the top right. He drew triangles, similar to those found in the Venus cartoon. Inside the triangles the following words appear, reading from left to right: Planet, Jupiter, Mars, Venus, and Sol (see Figure 10b). This distribution is equal to the one drawn in the cartoons of Venus and Jupiter. A long arrow from the triangle depicting the sun is drawn to point down to the image of the Sun planet, similarly was indicated in the cartoons of Venus and Jupiter.

\section{Cultural Sources for the Planets Cycle}

Burne-Jones's writings, such as the records at the Fitzwilliam Museum of Art and the recollections of his wife, Georgiana MacDonald (1840-1920), assist in understanding the scope of his interest in astronomy. The astronomical books that he collected and viewed at the British Museum contributed to his creative quest. He was captivated by the study of astronomy, as indicated by: 1) his personal notations on astronomy; 2) British scientific events (astronomical discoveries at the time); 3) British literary collections on astronomy (poems, books, manuals, celestial maps, playing cards); and 4) Italian literary and visual sources on astronomy and astrology.

\footnotetext{
75 See Mulryan, Vincenzo Cartari, 246; and Sesti, The Glorious Constellations, 379-382. In the Spring Seasons cycle, Burne-Jones represents Apollo holding and playing the lyre differently. The lyre's design is similar to a psalter, not a turtle shell.

76 See Sesti, The Glorious Constellations, 361-367; Zuffi and Novellone, Arte e Zodiaco, 93-98; and Allen, Star Names and Their Meanings, 252-258.

77 See Mulryan, Vincenzo Cartari, 53, the laurel leaves, alluding to their inner quality of fire; hence the laurel leaves are associated with the Sun as well.
} 
In Memorials of Edward Burne-Jones, Georgiana MacDonald recounted how fascinated he was with the study of astronomy. She wrote: "He kept astronomical books at his bedside, and often turned to them when unable to sleep." another passage, Georgiana repeated that "Astronomy had a great fascination for him—almost a terrible one.",0 One year after his trip to Italy in 1871, Burne-Jones composed a list of the paintings he was working on, mentioning that he made "an oil picture of Luna, in tones of blue" (Figure 16). ${ }^{81}$ After the death of his friend and soulmate, Morris, Burne-Jones decided to delve further into astronomy. He stated: "So I've had to take to my astronomy again." 82

British scientific culture and discoveries provided impetus for Burne-Jones's artistic expression in representing astronomical imagery. ${ }^{83}$ In 1781, William Herschel (together with his sister Caroline) discovered Uranus. Both were also musicians; William composed music and conducted the Bath Orchestra. ${ }^{84}$ In 1822 , Alexander Jamieson published a Celestial Atlas with G. \& W.B. Whittaker and Co. in London. William Lassell made new astronomical discoveries such as the largest moon of Neptune (Triton) in 1846 and (together with William Cranch Bond and George Phillips Bond) a moon of Saturn (Hyperion) in 1848. In 1851, William Lassell recorded Uranus's moons (Ariel and Umbriel). In 1859, Richard Christopher Carrington and Richard Hodgson (independently) made the first observations of a geomagnetic solar storm. In 1864, William Thomson discovered the thermodynamics of the earth and estimated the earth's age to be about 20 million years. And in 1873, George Biddell Airy explained and improved upon the orbital theory of Venus and the Moon.

Jamieson's Celestial Atlas inspired an important market for cartographic maps and playing cards in London. The Rev. Richard Bloxam popularized Jamieson's atlas by composing a set of playing cards based on planetary constellations, which were printed by Samuel Leigh for The Royal Astronomical Society in London in 1825 under the title of Urania's Mirror or A View of the Heavens. ${ }^{85}$

Moreover, these British scientific discoveries and media applications provided inspiration for Pre-Raphaelite artistic expressions not just in painting but also in poetry. Alfred Tennyson composed poems on

78 See GBJ Memorials, 2:304.

79 See GBJ Memorials, 1:58.

${ }^{80}$ See GBJ Memorials, 2:304.

${ }^{81}$ See GBJ Memorials, 2:30. Luna is an oil painting on canvass ( 101 x $71 \mathrm{~cm} ; 393 / 4$ x $28 \mathrm{in}$.) and signed with initials "EBJ" at the lower left. Alexander Ionides (1840-1898) owned the painting. Before his death it was sold anonymously to Christie's London, 1 March 1897, lot 121, then re-acquired by Christie's London in 1898 and sold as lot 21 on 15 May 1902 to Agnew R.H. Benson (1839-1912). The painting was eventually purchased and was part of the Collection Yves Saint Laurent et Pierre Bergé in Paris, who sold it to Christie's (lot/sale 1209), 23-25 February 2009, Paris. See http://www.christies.com/=lotfinder/-paintings/sir-edward-coley-burne-jones-bart-ara-rws-5157409-details.aspx 2009. See also Liana De Girolami Cheney, "Edward Burne-Jones's The Planets: Luna, A Celestial Sphere", in Culture and Cosmos: Journal for the History of Astrology and Cultural Astronomy (Spring/Summer 2017). After the 2009 Christie's sale, the painting became part of a private collection. The description of the painting, the size $(101 \times 71 \mathrm{~cm}$. (393/4 x $28 \mathrm{in}$.), materials (oil on canvas), and the signature with the monogram of 'EBJ' on the lower left of the painting attest and coincide with the description of the painting mentioned by GBJ Memorials, 2:30.

82 See GBJ Memorials, 2:303.

${ }^{83}$ See Peter Whitfield, Astrology: A History (New York: Harry N. Abrams, 2001), 165-179, for a discussion on astrology in England between 1550 and 1700 .

84 In 1780, William Herschel was appointed director of the Bath Orchestra, while his sister Caroline performed as a soprano. They lived at New King Street in Bath, UK, today the residence of the Herschel Museum of Astronomy. See Richard Holmes, The Age of Wonder (New York: Vintage Books, 2008).

${ }^{85}$ See facsimile edition of the First American Edition of Urania's Mirror, 1832 (New York: Barnes and Noble, 2004), and http://www.atlascoelestis.com/16.htm. See also n. 69 above. 
astronomy and cosmology such as Maud, Lucretius, on Herschel's great star, ${ }^{86}$ and In Memoriam; Gabriel Dante Rossetti wrote a stanza on A Match With The Moon; ${ }^{87}$ his sister, Christina Georgina Rossetti, poetically questioned the colors of the moon in Is the Moon Tired? She Looks so Pale? $;^{88}$ and Morris evoked the beauty

${ }^{86}$ Alfred Tennyson, Maud (1855):

Come, into the garden, Maud,

For the black bat, Night, has flown,

Come into the garden, Maud,

I am here at the gate alone;

And the woodbine spices are wafted abroad,

And the musk of the roses blown.

For a breeze of morning moves,

And the planet of Love is on high,

Beginning to faint in the light that she loves

On a bed of daffodil sky,

To faint in the light of the sun she loves,

To faint in his light, and to die.

Alfred Tennyson's Lucretius (first published in Macmillan's Magazine, May 1868):

The Gods, who haunt

The lucid interspace of world and world,

Where never creeps a cloud, or moves a wind ...

Nor sound of human sorrow mounts to mar

Their sacred everlasting calm! and such,

Not all so fine, nor so divine a calm

Not such, nor all unlike it, man may gain

Letting his own life go.

${ }^{87}$ Dante Gabriel Rossetti's A Match With The Moon (1881):

Weary already, weary miles to-night

I walked for bed: and so, to get some ease,

I dogged the flying moon with similes.

And like a wisp she doubled on my sight

In ponds; and caught in tree-tops like a kite;

And in a globe of film all liquorish

Swam full-faced like a silly silver fish;

Last like a bubble shot the welkin's height

Where my road turned, and got behind me, and sent

My wizened shadow craning round at me,

And jeered, "So, step the measure, one two three!"

And if I faced on her, looked innocent.

But just at parting, halfway down a dell,

She kissed me for good-night. So you'll not tell.

${ }^{88}$ Christina Georgina Rossetti's Is The Moon Tired? She Looks So Pale (1872):

Is the moon tired? she looks so pale

Within her misty veil:

She scales the sky from east to west,

And takes no rest.

Before the coming of the night

The moon shows papery white;

Before the dawning of the day

She fades away. 
of the planet Earth in Flora and Earth the Healer. ${ }^{89}$ Burne-Jones visualized their poetical visions and formulated his own astronomical ideas into a fanciful stellar ensemble in the Planets.

During his many journeys to Italy, from 1859 until 1871, Burne-Jones became interested in Italian culture, including literature and visual arts. Among the Italian Renaissance literary sources was Francesco Colonna's Hypnerotomachia Poliphili [The Dream of Poliphilo or The Strife of Love in a Dream], published in Venice in 1499 by Aldo Manutius, ${ }^{90}$ which was another inspiration for Burne-Jones' astronomical creations. He considered Colonna's tome the most beautiful printed and illustrated book of the Italian Renaissance. He owned a copy, a gift from Morris, which is now at the Houghton Library in Cambridge, MA. ${ }^{91}$ Colonna explained the function of the planets and their innate qualities of order, governance, and harmony of the spheres. ${ }^{92} \mathrm{He}$ elaborated upon a system dealing with the eternal and the physical realms as manifested in the text through Poliphilo's journey. He guided "the reader through an initiation rite composed of different phases and realities, for the purpose of arriving at a consciousness where body and soul are united through the metamorphoses of love between Poliphilo and Polia." 93

Travelling from Rome to Milan and Venice and their surroundings areas, Burne-Jones experienced the visual presence of the Renaissance's cosmology as depicted in numerous ceilings and walls of churches and palaces. For example: in Florence, Brunelleschi's Medicean astrological cupola of 1424 in the Old Sacristy of San Lorenzo; in Padua, Niccolò Miretto and Stefano da Ferrara's Labours of the Months, the seasons and the

\footnotetext{
${ }^{89}$ William Morris's Earth The Healer (1875):

Think of the thankless morning,

The gifts of noon unused;

Think of the eve of scorning,

The night of prayer refused.

And yet. The life before it,

Dost thou remember aught,

What terrors shivered o'er it

Born from the hell of thought?
}

William Morris's Flora, (1885):

I am the handmaid of the earth, I broider fair her glorious gown, And deck her on her days of mirth With many a garland of renown. And while Earth's little ones are fain And play about the Mother's hem I scatter every gift I gain

From sun and wind to gladden them.

90 The first edition of Hypnerotomachia Poliphili or Il Sogno di Polifilo was considered the most beautifully illustrated Renaissance book. Leonardo Crasso from Verona, who financed the printing, dedicated it to the Duke of Urbino, Guido da Montefeltro. See Lilian Armstrong, "Benedetto Bordon, Aldus Manutius and Lucantonio Giunta: Old and New Links," in Lilian Armstrong, Studies of Renaissance Miniaturists in Venice, 2 vols. (London: Pindar, 2003), 2:161-183.

${ }_{91}$ See Mark Samuel-Lasner, "Note on Burne-Jones's Hypnerotomachia Poliphili," Pre-Raphaelite Review 1 (1978): 110; and Harrisons and Waters, Burne-Jones, 81-83.

92 See Joscelyn Godwin, The Pagan Dream of the Renaissance (Grand Rapids, MI: Phanes, 2002), 32, 36, on the planets and their association with the cult of Venus.

93 See Esteban Alejandro Cruz, Hypnerotomachia Poliphili: An Architectural Vision, 2 vols. (USA: Xlibris, 2011), 1:201; and Godwin, Pagan Dream of the Renaissance, 30. 
zodiac signs of 1425-1440 in the Palazzo della Ragione; and in Rome, Baldassare Peruzzi's ceiling with the family Chigi's astrological chart in the Loggia of Galatea of 1515 at Villa Farnesina. Burne-Jones must also have been mesmerized and absorbed by the astrological and astronomical representations of Francesco Cossa and Cosmé Tura's wall decorations in the Hall of the Months of 1470-1484 at the Palazzo Schifanoia in Ferrara (Figure 17). These astrological seasonal cycles designed for the duke of Ferrara, Borso d'Este, were programmed after the ancient astrological manuscript of Hyginus's Poeticon Astronomicon, published unillustrated in Ferrara 1475 and with illustrations in 1482 (Figure 18). ${ }^{94}$ As a frequent visitor to the British Museum - and because of his love for illuminated manuscripts and avid interests in astronomy noted in his wife's memoirs - it is indubitable that Burne-Jones was familiar with Hyginus's astrological manuscript (Harley MS 647) housed in the library. ${ }^{95}$

Moreover, during his trips from Bologna to Parma and Milan, Burne-Jones undoubtedly visited Ferrara and Modena. ${ }^{96}$ With his fascination for astronomical texts, he probably consulted the most popular and beautiful astrological manuscript of the Italian Renaissance by Cristoforo de Predis (1440-1486), De Sphaera of 1470 located in the Biblioteca Estense Universitaria in Modena. This tome encapsulated the planetary celestial and terrestrial realms of mythological and astral accounts with symbolic allusions from antiquity through the Renaissance. Predis's De Sphaera, like Colonna's Hypnerotomachia Poliphili, was probably another pictorial jewel for Burne-Jones's magical mind.

A visual comparison with some of Predis's imagery assists in ascertaining the identification of the symbols in Burne-Jones's Planets. These planetary personifications are accompanied by constellations and signs of the zodiac, similarly visualized in Cossa and Tura's seasonal cycles at the Hall of the Months in Palazzo Schifanoia. However, in Renaissance and Pre-Raphaelite art, artists tended to represent the astral planets according to Ptolemy's celestial map and took artistic license in their representations, mixing and matching the constellations - a cluster of stars forming an astral pattern identified with mythological figures - with the zodiac signs - a "circle of animals" forming an ecliptic path around sun - and the planetary gods who ruled the zodiac band formed in the sky. Although interested in astronomy and passionate about astronomical visual texts, Burne-Jones also took liberties in the composition of his Planets cycle. For example, Venus holds a mirror as symbol of light and beauty; this planet rules the houses of Taurus with the bull and Libra with the scale. Venus partakes of their constellations Taurus and Libra (compare Figures 2 and 19). Luna (the Moon) on a boat (Argo Navis) controls the seas and rules the houses of Cancer and is represented by the zodiac sign of the crab (compare Figures 3 and 20). She partakes of the constellations of Argo Navis and

\footnotetext{
94 See Hyginus, Poeticon Astronomicon with the illustrations of the constellations and planets, ed. Jacobus Sentinus and Johannes Lucilius Santritter (Venice: Erhard Ratdolt, 1482/3).

95 See GBJ Memorials 2:279; and London, British Library, Harley MS 647, 820-11th century. This collection contains the following astronomical texts and diagrams: 1) Astronomical texts based on Isidore of Seville, with two short prayers (fols. 1r-2r); 2) Marcus Tullius Cicero, Aratea, with twenty-two constellation figures containing extracts from Hyginus, Astronomica (fols. 2v-17v); 3) Excerpts from Pliny, Natural History, Macrobius, Commentary on the Somnium Scipionis, and Martianus Capella, De nuptiis Philologiae et Mercurii, books 8 and 6 (known as The Seven-Book Computus (fols. 17v-20r and 16r-16v [margin]); and 4) Diagram of the Northern and Southern Hemispheres (fol. 21v). Decoration: twenty-two full-page representations of the constellations in colors (fols. 2v-6r, 7r-13v); a full-page diagram of the constellations in brown ink (fol. 21v); and a large diagram of the solar system in brown and red (fol. 19r).

96 See Oliver Garnett, "The Letters and Collection of William Graham: Pre-Raphaelite Patron and Pre-Raphael Collector," The Volume of the Walpole Society 62 (2000), 145-343, for a discussion of Graham's (1817-1885) travels to Italy, collecting works of old masters, e.g., Bernardino Licinio's Portrait Group of the Ducal Family of Modena of 1522 (sold in 1886 in London, noted in the Bazaar The Exchange and Mart., Mon., 8 Jan. 1894, 62). He also sponsored Dante Gabriel Rossetti and Burne-Jones, sharing with them his artistic vision, traveling experiences, and access to his collection.
} 
Cancer. Mars, the red planet, with the zodiac sign of scorpion, rules the house of Scorpio and with the ram rules the house of Aries. But Burne-Jones replaced the traditional tame ram as a symbol of Aries with a fierce feline, perhaps a puma, lynx or wolf, making Mars partake of the constellation of Lupus as well. He also replaced a Medusa's head with a lion's head in Mars's shield, alluding to the constellations of Perseus and Orion (compare Figures 7 and 21). Hence Mars partakes of several constellations, including Aries, Orion, Perseus, and Scorpio. ${ }^{97}$ The Sun God Apollo, while playing the lyre, rules the house of Leo with the sign of the lion (compare Figures 10 and 22) and partakes of the constellations of Leo and Lyra. Saturn, the oldest planet, rules the houses of Aquarius and Capricorn with the zodiac signs of the water-carrier and sea-goat. But Burne-Jones substituted for the sea-goat a winged serpent or dragon (draco) and added the twins as zodiac signs from the house of Gemini (compare Figures 6 and 23). Hence Saturn partakes of the constellations of Aquarius, Gemini, and Ophiuchus and the Serpent. Jupiter rules the houses of Pisces and Sagittarius with their zodiac signs of fishes and the centaur, partaking as well of the constellations of Pisces and Sagittarius. But Burne-Jones also focused on the cosmic regal power of Jupiter by adding the attribute of the thunderbolt (compare Figures 9 and 24). Burne-Jones's creation of the planet Earth (Terra) was a confusing combination of attributes from the elements of nature - a maiden, a child, water, a serpent, and a dog-hence partaking of the constellations of Virgo (trees), Aquarius, (water), and Dog-Sirius (the sky) ${ }^{.98}$

\footnotetext{
97 See Cresswell, Legendary Beasts of Britain, 24. Puma and lynx were seen in Invernesshire. By associating the puma, a local feline animal, with Mars, rather than the traditional tame ram, Burne-Jones better expressed Mars's fierce temperament and fearlessness. These traits are symbolized in the selection of the aggressive animals and predators, the puma and the scorpion, depicted in the cartoon. The planet Mars rules the house of Scorpio, which is the eighth sign of the zodiac and is represented by a scorpion, hence the inclusion in the cartoon.

98 See P. G. Maxwell-Steward, Astrology: From Ancient Babylon to the Present (Stroud, UK: Amberley, 2010), 2-44; Allen, Star Names and Their Meanings, 10-30; and Giuseppe Maria Sesti, The Glorious Constellations. On 19 January 21016, I presented a lecture on "Edward Burne-Jones's Terra (Earth Mother)" at the Worcester Art Museum, MA, where I discussed the iconography of their small painting, Terra, in connection to the drawing as well as to astral and terrestrial symbolism.
} 


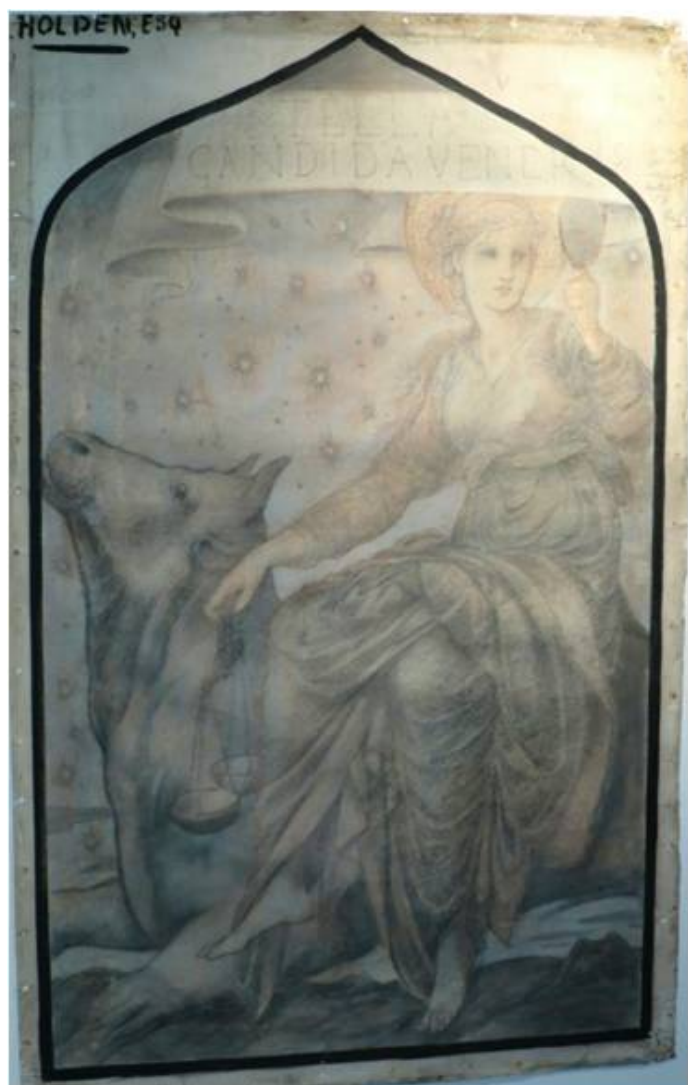

Figure 2. Edward Burne-Jones, Venus (Stella Candida Venere) 1879 , cartoon.

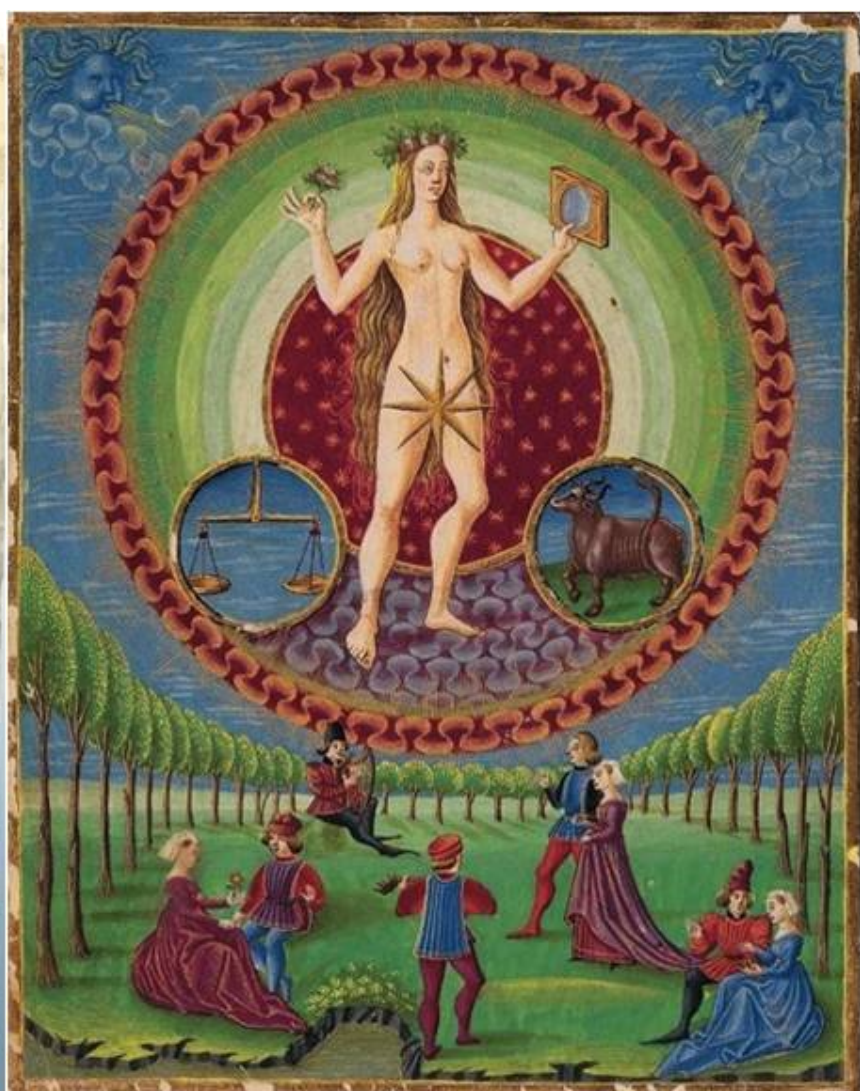

Figure 19. Cristoforo de Predis, Venus, 1470, from manuscript De Sphaera. Biblioteca Estense Universitaria, Modena. 


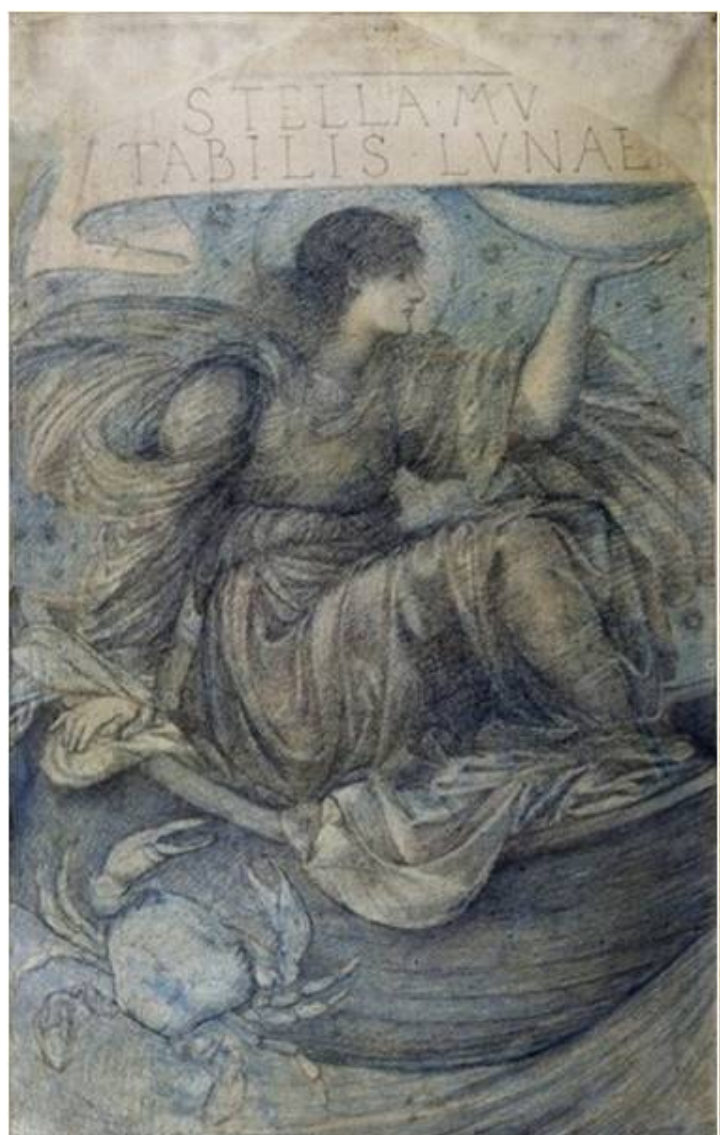

Figure 3. Edward Burne-Jones, Luna (Moon) (Stella Mutabilis Lunae) 1879, cartoon.

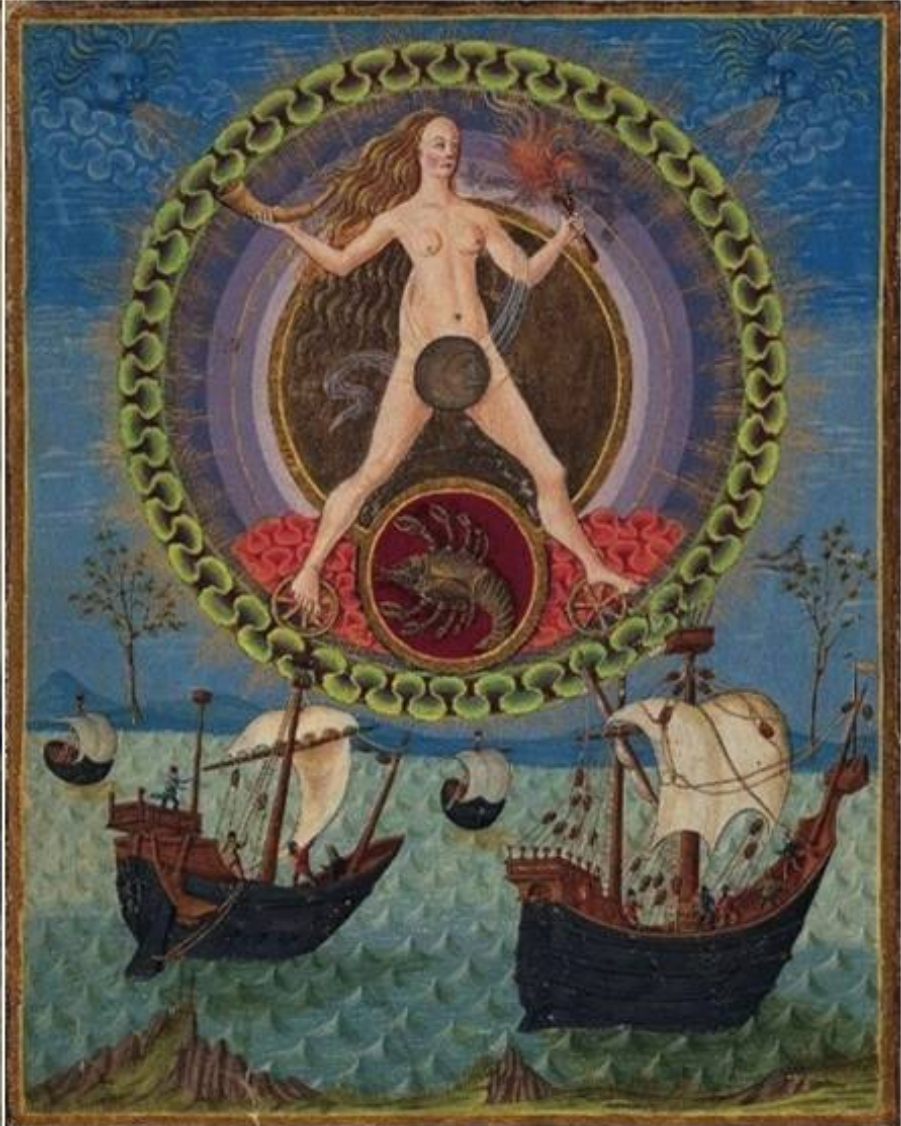

Figure 20. Cristoforo de Predis, Luna, 1470, from manuscript De Sphaera. Biblioteca Estense Universitaria, Modena. 


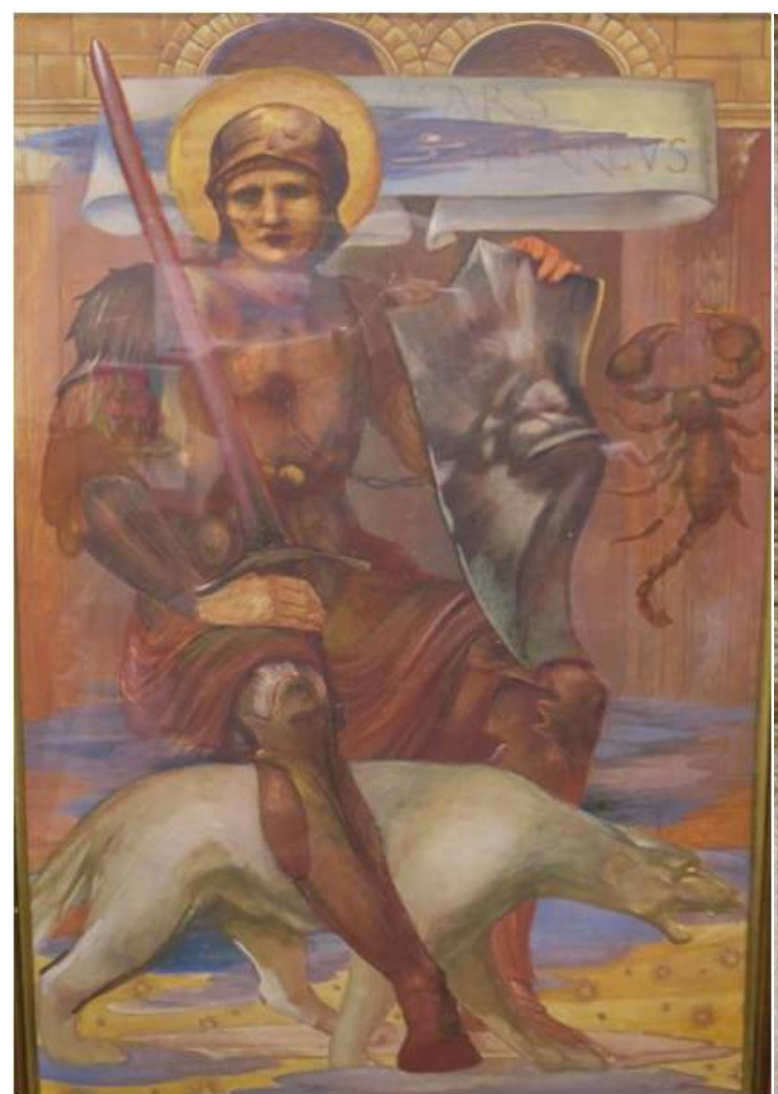

Figure. 7. Edward Burne-Jones, Mars (Mars Terreus), 1879, cartoon.

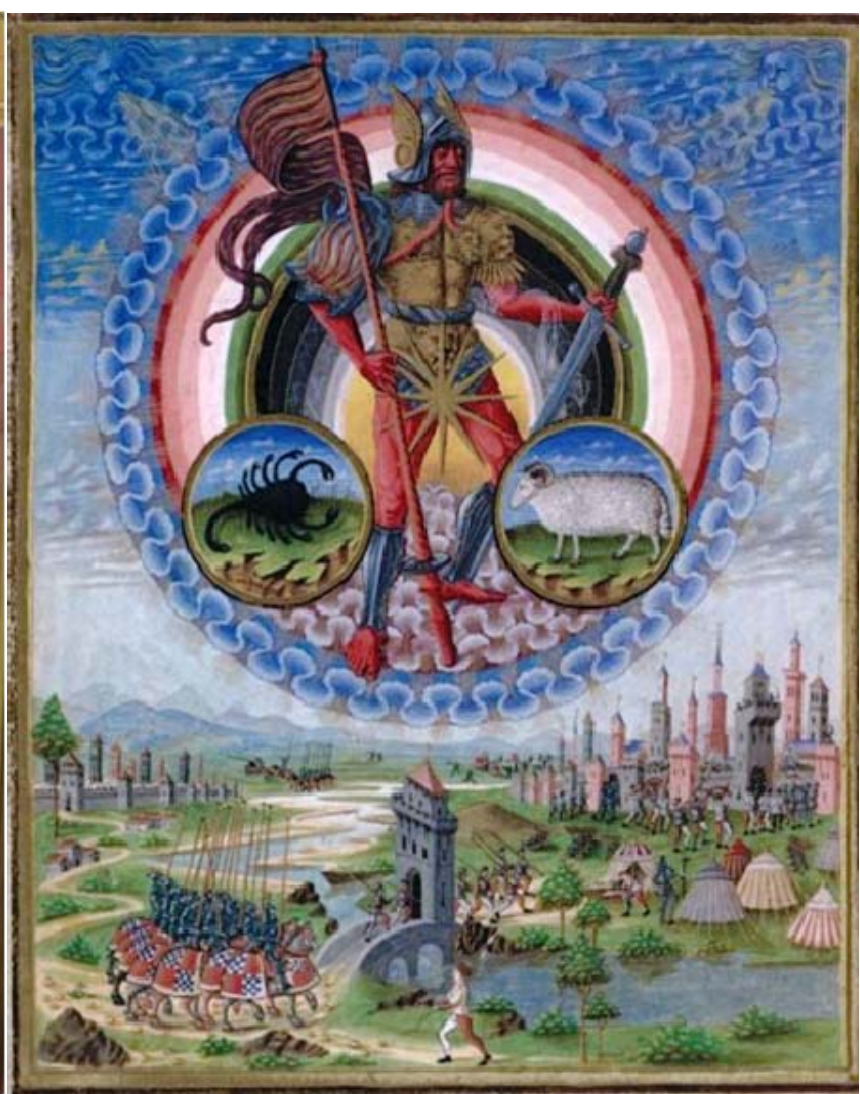

Figure 21. Cristoforo de Predis, Mars, 1470, from manuscript De Sphaera. Biblioteca Estense Universitaria, Modena. 


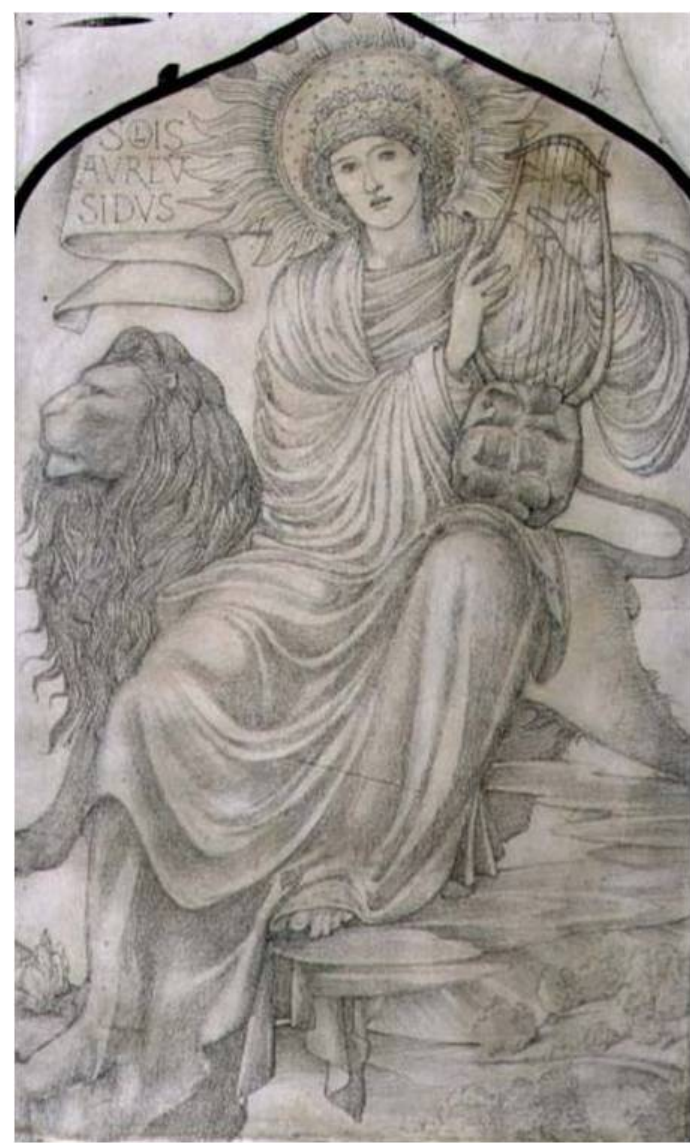

Figure 10. Edward Burne-Jones, Sun (Apollo) (Solis Aureus Idus), 1879, cartoon

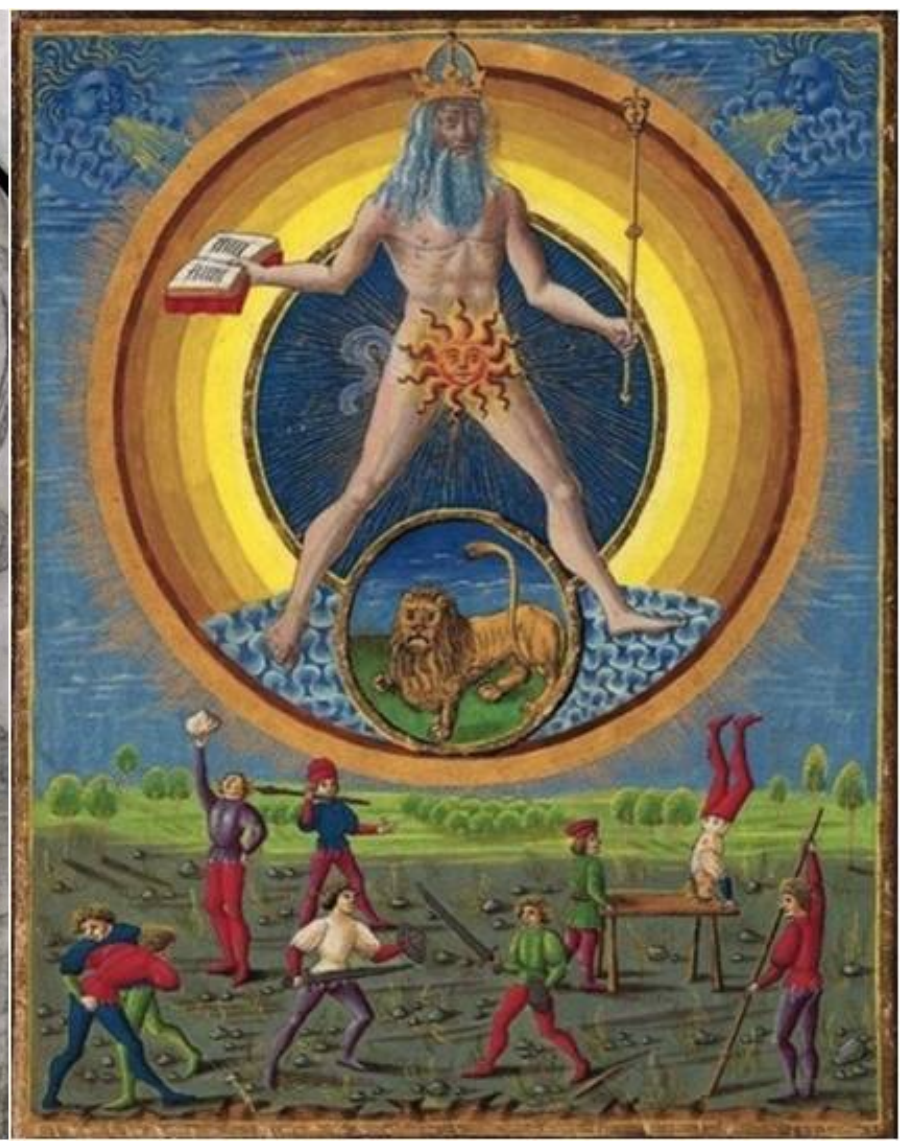

Figure 22. Cristoforo de Predis, Sol, 1470, from manuscript De Sphaera. Biblioteca Estense Universitaria, Modena. 


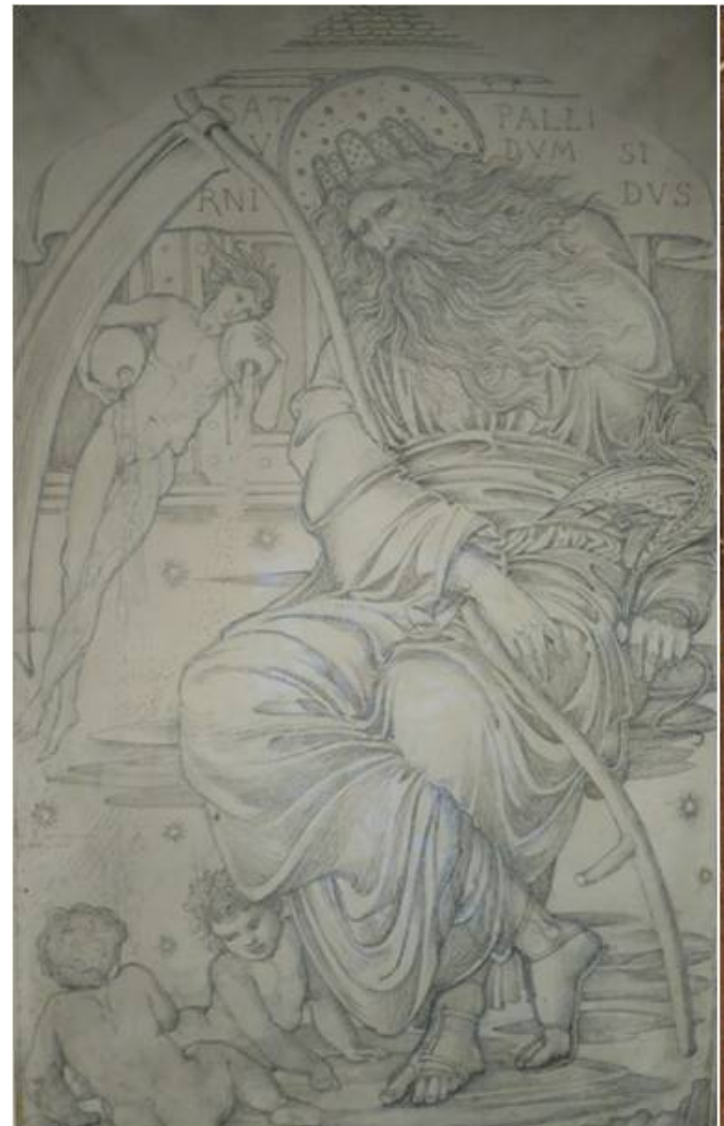

Figure 6. Edward Burne-Jones, Saturn (Saturn Palladium Sidus), 1879, cartoon

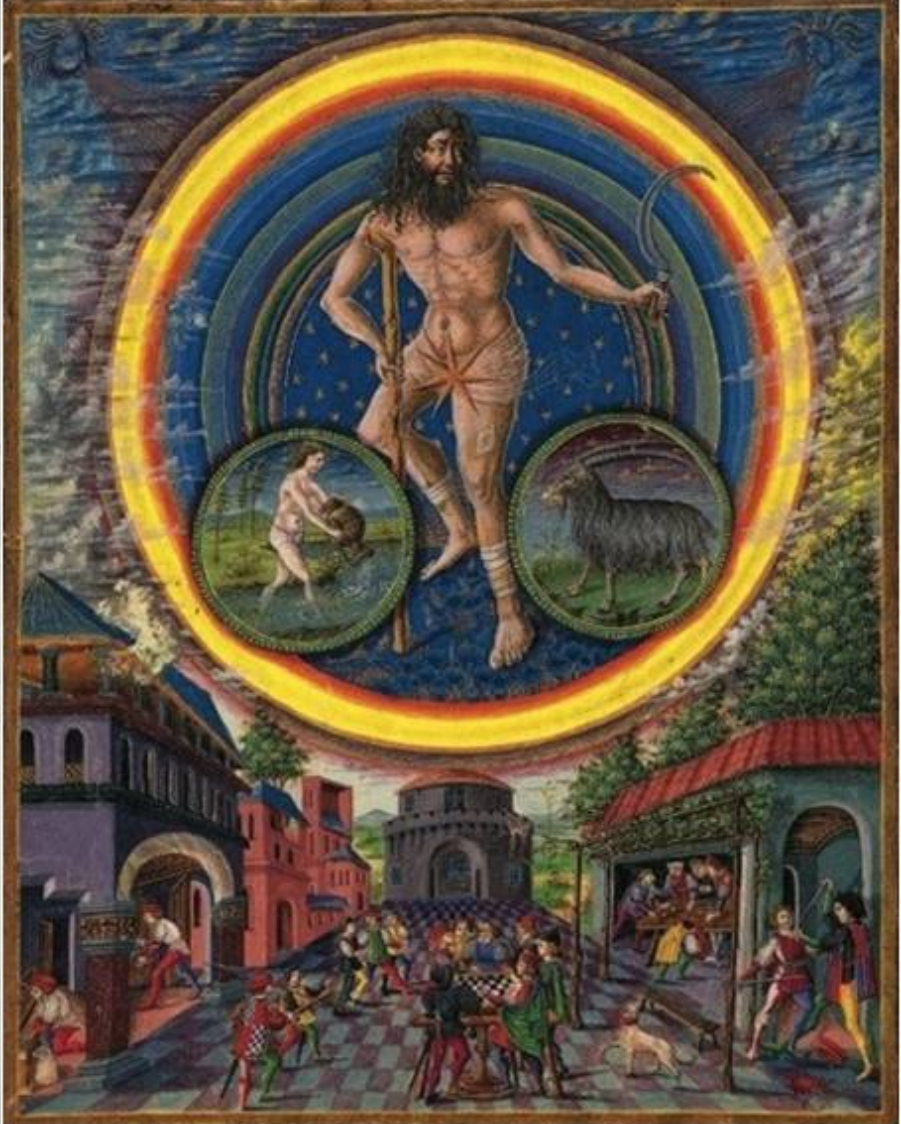

Figure 23. Cristoforo de Predis, Saturn, 1470, from manuscript De Sphaera. Biblioteca Estense Universitaria, Modena. 


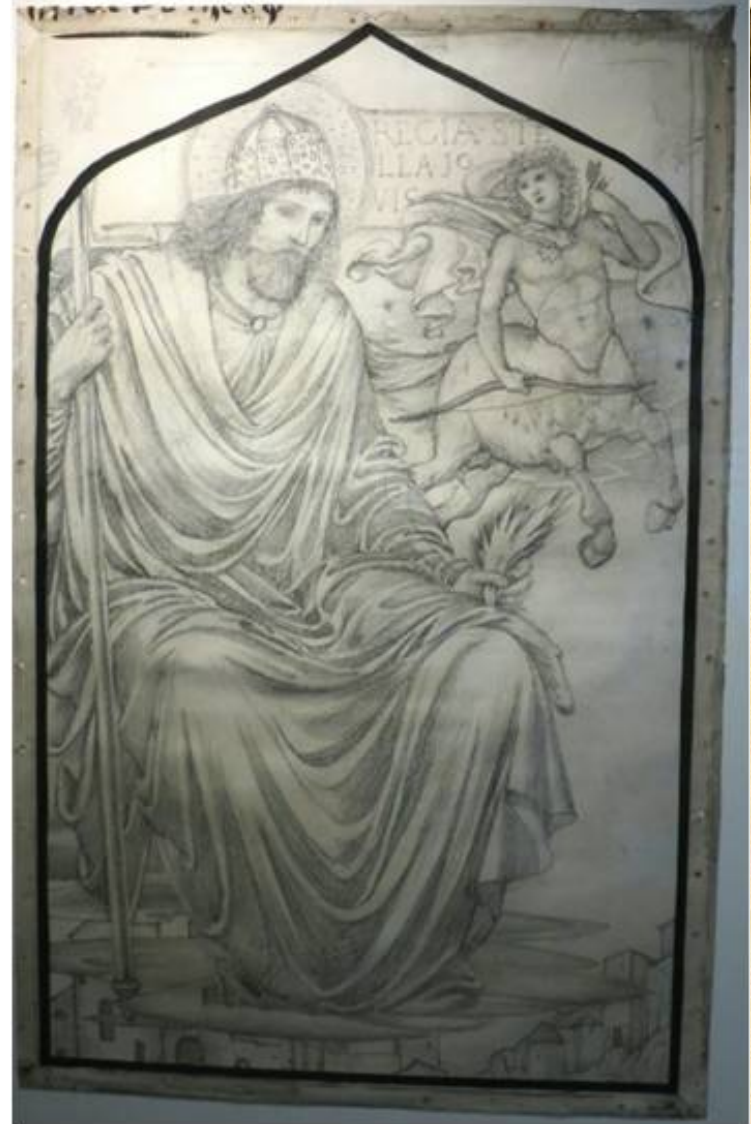

Figure 9. Edward Burne-Jones, Jupiter (Regia Stella Jovis), 1879 , cartoon

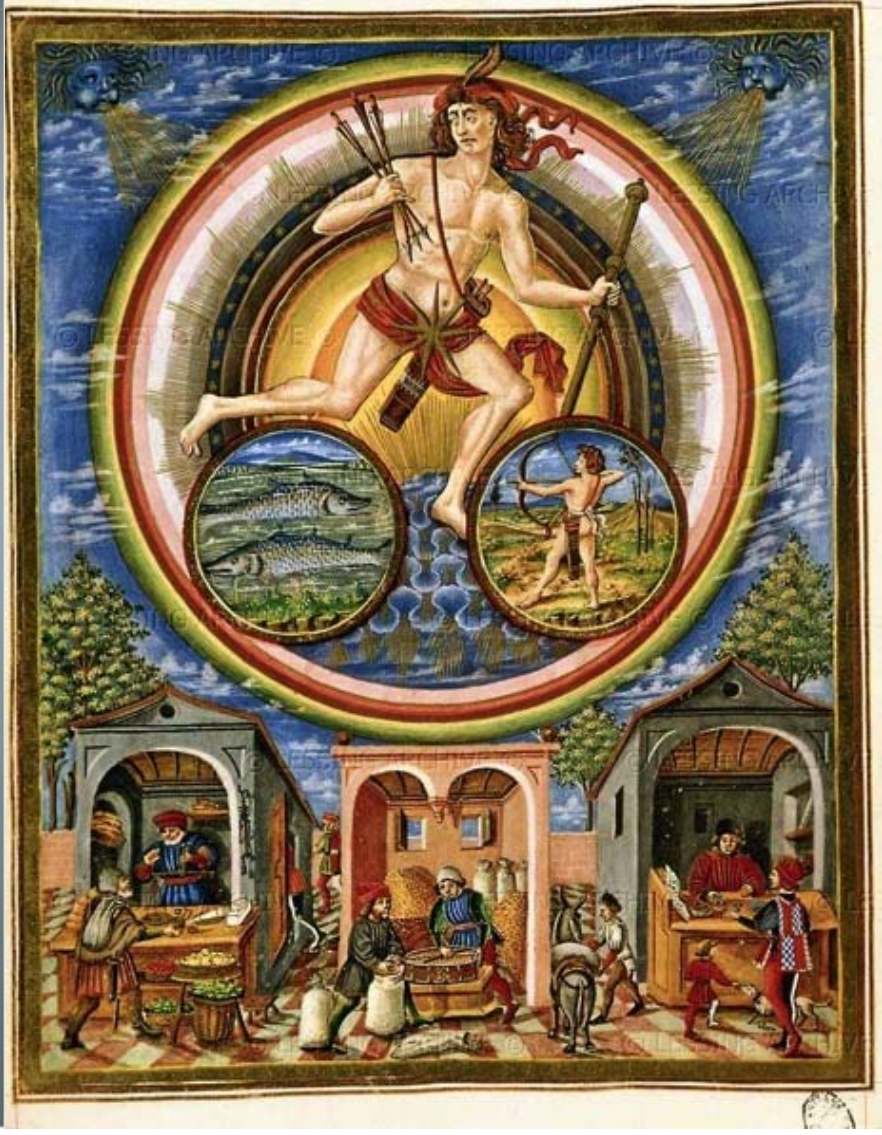

Figure 24. Cristoforo de Predis, Luna, 1470, from manuscript De Sphaera. Biblioteca Estense Universitaria,

Modena.

Along with Morris, Burne-Jones belonged to the Society of Antiquaries and frequently visited their library to admire the illuminated manuscripts, noting: "We made our little pious pilgrimage together to see the beautiful books." $"$ In the Memorials, Georgiana wrote: "Edward's love for illuminated manuscripts never flagged; in quite late years he said, 'To this day if I want a change happier, brighter, and more in tune with my heart's desire than any other, I go to the British Museum and send for a book that took a lifetime to make, and then forget the world and live in that book for days." $" 100$ These literary and visual experiences had a significant impact on Burne-Jones's creativity, intellectually fusing the Italian visual experience of astronomical imagery with ancient illuminated manuscripts on astral conceits in the Planets cycle.

\section{Coda: Misfortune of the Stained-glass Panels}

A few notations, although inconclusive on the problematic quest for the history of the Burne-Jones's Planets cycle's cartoons transferred into stained-glass panels, might encourage more scholars to seek further information on this dilemma. A publication of 1885 refers to the placement of Burne-Jones' Planets with this notation: "The music room, added to the north-east end of Woodlands some years after the original construction

\footnotetext{
99 See GBJ Memorials 2:279; and Susan Pearce, ed., Visions of Antiquity: The Society of Antiquaries of London 1707-2007 (London: Society of Antiquaries, 2007), for the history of this prestigious library.

${ }^{100}$ See GBJ Memorials 2:279; and Harrisons and Waters, Burne-Jones, 72, 45-47.
} 
was finished ... includes a large window containing in its upper compartment nine stained glass figures, the work of the celebrated artist Burne-Jones." ${ }^{\text {"101 }}$ Many scholars and auctioneers attempted to find the original or copies of Burne-Jones's glass panels based on his cartoons, without clear solutions. ${ }^{102}$ At present the following can be surmised. To date, there is no knowledge of a complete set of Burne-Jones's Planets cycle. Between 1885 and 1996, several partial duplications or copies of the Planets cycle's cartoons discussed in this essay were made. ${ }^{103}$ The Morris Company's Catalogue of Designs Used for Windows Executed from June 1876 to 30 June 1916, a significant source of information on the Firm, only records the last name of the artisan who transferred the cartoons into a glass panel. ${ }^{104}$ The entry of July 1879 records, for example, the following: BJ (initials for Burne-Jones) Venus (BJ341) painted by Bowman; Luna (BJ345) painted by Fletcher and Stokes; Morning Star (BJ343) painted by Egan; Evening Star (BJ342) painted by Bowman; Mars (BJ346) painted by Egan; Jupiter (BJ354) painted by Fletcher; Sol (BJ353) painted by Bowman and Watson [Sol is a variant on Burne-Jones' Apollo cartoon]; Earth (Terra) (BJ355) painted by Titcomb; artist's name is not recorded for Saturn (BJ344). ${ }^{105}$ A confusing entry records that in the final design for the window, at the top of the window was Moon, on the left, Earth in the center, and Sol, on the right, with no indication of the placement of the other planets. Still there are not clear indications of how the Planets cycle was displayed in Woodlands's window.

In 1970, Gabreal Franklin, auctioneer of the Franklin Collection of London, claimed to have located seven glass panels of the Planets cycle: Venus, Morning Star, Evening Star, Luna, Jupiter, Mars, and Sol, with two original glass panels still missing, Saturn and Earth. ${ }^{106}$ The Franklin Collection sold five of the glass panels (Venus, Morning Star, Evening Star, Luna, and Jupiter) to Jimmy Page of LED ZEPPLIN, owner of one of William Morris' former homes (The Red House). The Franklin Collection kept two glass panels: Mars and Sol (Sun or Apollo). But in 2008 they sold the glass panel of Mars to the Los Angeles County Museum of Art. Presently they are seeking a buyer for the glass panel of Sol. In 2008 there was yet another change of hands: Jimmy Page's five glass panels were sold to the auction house of Paul Reeves of London, one of the finest Pre-Raphaelite collectors in England.

\section{Conclusion}

I would like to suggest an iconological signification for Burne-Jones's cartoons for the Planets cycle.

\footnotetext{
101 Archival assistance from the Torre Abbey Museum; Michael Rhodes, former Curator of Museum Services, Torre Abbey, U.K. (April 7, 2008); correspondence with Gabreal Franklin and his website, http://www.allplanet.com/glass/BJ5.htm (2009), on the History of Edward Burne-Jones's Planet as Stained Glass Window; and previous scholarly research assisted me in collecting this data. See Sewter, The Stained Glass of William Morris and His Circle, 208, for a discussion of the windows made for Holden's Woodlands in 1879; and Wildman and Christian, Edward Burne-Jones, 273-275.

102 See Sewter, The Stained Glass of William Morris and his Circle, 208; William Morris's Catalogue of Designs Used for Windows Executed from June 1876 to 30 June 1916, revised (Walthamstow: William Morris Gallery, 1969); and Franklin Collection online, http://www.allplanet.com/glass/BJ5.htm (2009).

${ }^{103}$ See Sewter, "In Notes on Morris \& Co.’s domestic stained glass," 20-25, 22. In 1903, James Wilcox, J. P., commissioned a set of stained-glass windows based on the cartoons of Burne-Jones's Planets for his home Wilmar Lodge in Pleasington, Blackburn, Lancaster. The window was planned for a main staircase decoration. In 1958, Wilcox's window setting was dismantled, bequeathed and moved to the Queen Elizabeth's Grammar School in Blackburn. In January 2017 I contacted the director of the lodge, who claimed that there are no glass panels in the establishment. Recently, in 1996, in honor of the 50th anniversary of the founding of the Torre Abbey Museum, the Friends of Torre Abbey Museum commissioned one stained-glass window based on their own Burne-Jones's cartoon of Earth.

104 See William Morris's Catalogue of Designs Used for Windows Executed from June 1876 to 30 June 1916, revised 1969.

105 See Sewter, The Stained Glass of William Morris and his Circle, 208; and Sewter, "In Notes on Morris \& Co.'s domestic stained glass," 20-25.

106 See http://www.allplanet.com/glass/BJ5.htm.
} 
Burne-Jones envisioned the planets as personifications of natural and metaphysical goodness. These personifications partake of both the spiritual and physical realms. In the natural or physical realm, Burne-Jones associated the Planets cycle with the Seasons cycle, and in the metaphysical of spiritual realm he connected the Planets cycle with celestial divination and prophetic guidance. Since antiquity, the quest for the complex signification of planetary movements and their terrestrial and celestial ramifications has been analyzed in terms of their associations with two distinct categories. First with the physical conditions of the natural world such as the seasons (winter, spring, summer, and fall); the elements of nature (air, water, fire, and earth); the ages of the individual (infancy, youth, adulthood, and old age); the humors (black bile of the gallbladder, phlegm of the brain and lungs, blood of the liver, and yellow bile of the spleen) associated in turn with the temperaments of the individual (choleric, phlegmatic, sanguine, and melancholic); and the senses of the individual (touch, smell, sight, taste, and hearing). Second with the observations of the planets' cosmic transformation, alignments, and celestial influences on human thought and behavior (personalities) and social environment (individual achievements, social interactions, and roles in society). ${ }^{107}$

In the Seasons and Planets cycles, Burne-Jones did not follow the classical and Renaissance traditions, as had Baldini or de Predis in associating the seasons and the planets with astrological signs for the purpose of analyzing or predicting the individual's character, temperament, or personalities. Rather, Burne-Jones was probing into the visualization of the planets as astral forces in the firmament. He appropriated from Michelangelo's ignudi [nude youths], prophets, and sibyls in the Sistine Chapel ceiling their composition — such as their royal seated posture and peaceful attitude — as well as their meaning by capturing their projected powers of divination and creation (compare Figures 6 with 25 and 26; and Figures 2 and 27).

\footnotetext{
107 See Plato's Timaeus, 90a2-d7 and 90d5-7; D. J. Zeyl, trans, Plato: Timaeus (Indianapolis IN and Cambridge MA: Hackett Publishing Co. 2000); On Plato's Timaeus-Calcidius, ed. and trans. John Magee (Cambridge, MA: Harvard University Press, 2016), pp. 211-87 and 289-317; and F. M. Cornford, Plato's Cosmology (London: Routledge \& Kegan Paul, 1937, repr. Indianapolis In and Cambridge MA: Hackett Publishing Co., 1997). See also Joseph Alexander Leighton, Man and the Cosmos: An Introduction to Metaphysics (London: Appleton, 1922); Evan Hadingham, Early Man and the Cosmos (Norman: University of Oklahoma Press, 1985); Ernst Cassirer, The Individual and the Cosmos in Renaissance Philosophy (1963; repr. Chicago: University of Chicago Press, 2010); and Rupert Gleadow, The Origin of the Zodiac (New York: Dover, 2001), 62-86, esp. 80, for Plato's conception of the planets in relation to the twelve Greek Gods. Plato called the planets visible gods and the zodiac signs invisible forces, which are manifestations of creative forces in the cosmos.
} 


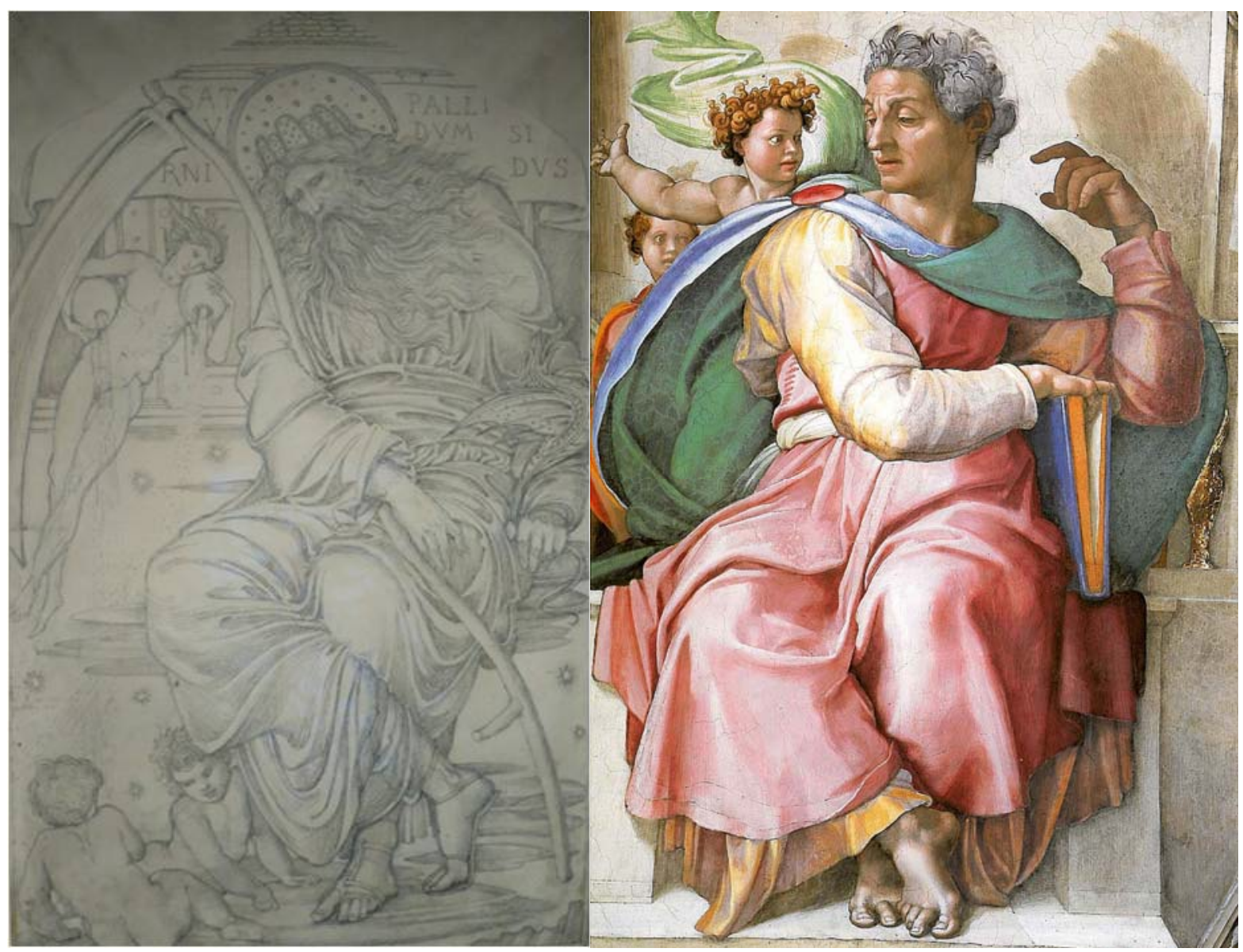

Figure 6. Edward Burne-Jones, Saturn (Saturn Palladium Sidus), 1879, cartoon
Figure 25. Michelangelo, Prophet Isaiah, 1509, ceiling. Sistine Chapel, Vatican. 


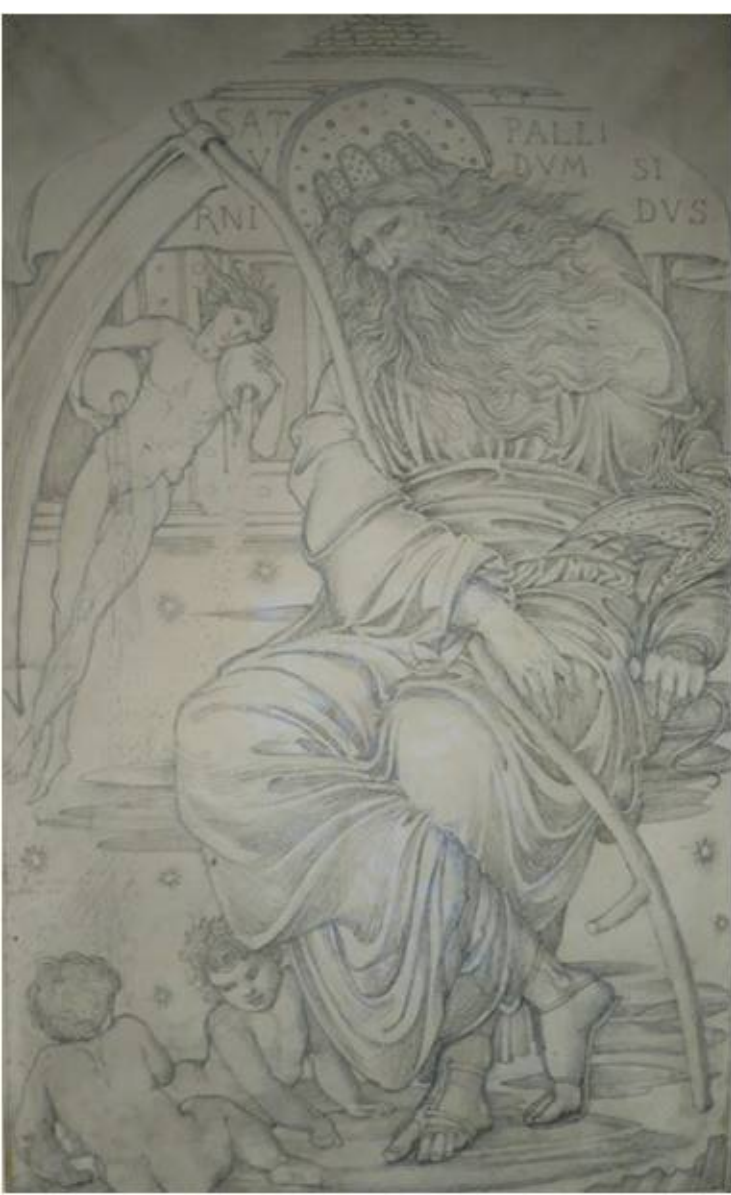

Figure 6. Edward Burne-Jones, Saturn (Saturn Palladium Sidus), 1879, cartoon.

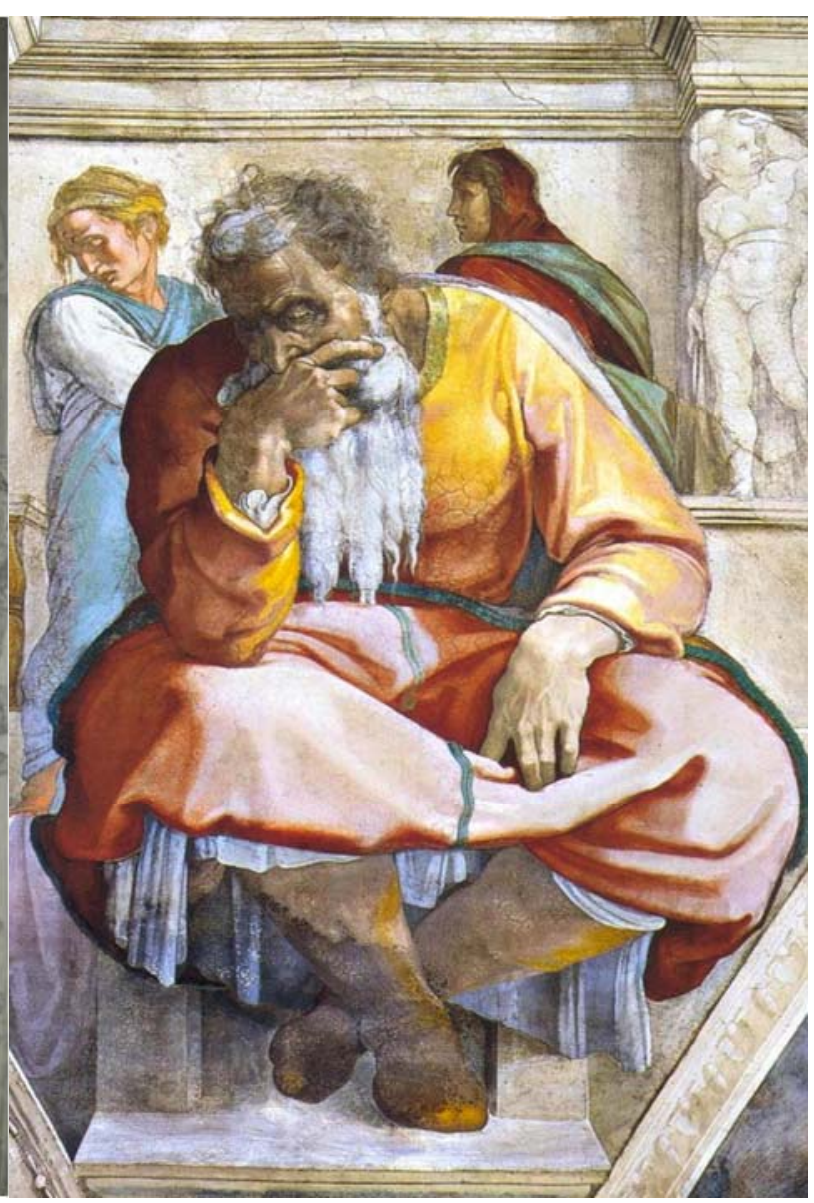

Figure 26. Michelangelo, Prophet Jeremiah, 1509, ceiling. Sistine Chapel, Vatican. 


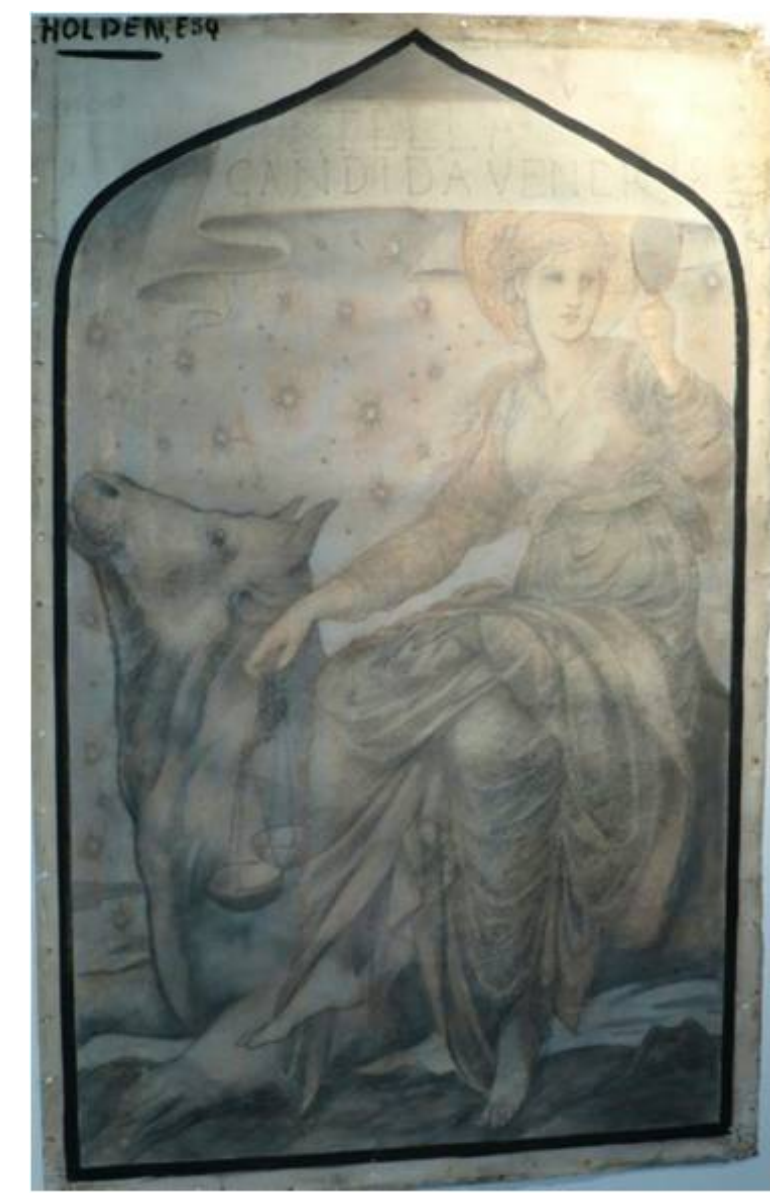

Figure. 2. Edward Burne-Jones, Venus (Stella Candida Venere) 1879 , cartoon

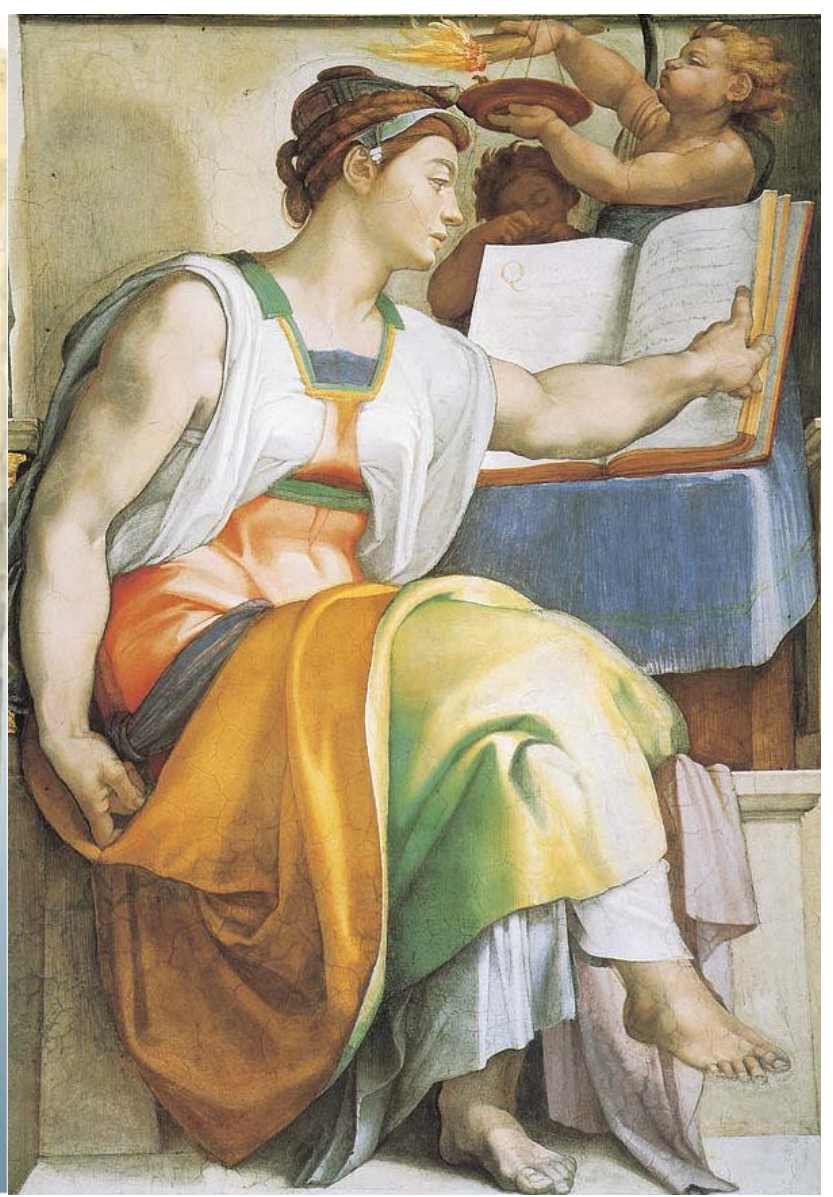

Figure 27. Michelangelo, Erythraean Sibyl 1509, ceiling.

Sistine Chapel, Vatican

Michelangelo depicted genii as astral sources of inspiration and benevolent guidance, ${ }^{108}$ while Burne-Jones drew constellations and zodiac signs to convey the positive destiny of the cosmos. The majestic figures portrayed in the Planets cycle suggest that Burne-Jones depicted them as monumental guardians of the celestial sphere. He surrounded their heads with specific allusions to sacred forms or entities such as halos (a celestial attribute) or a crown (a regal allusion) with specific attributes. For example, Luna is decorated with a bluish luminous ring alluding to a full moon; Venus has a golden starry disk alluding to her colored light source, and Earth has no halo because she is a terrestrial planet. Burne-Jones depicted Mars wearing a warrior helmet surrounded by a solid golden disk; Jupiter with a celestial aura wears a royal crown with jewels; Apollo's starry halo transforms into an open sunflower, an allusion to the sun, while he is crowned with laurel and oak leaves, a poetical touch; and Saturn is portrayed as a Moses-type with a galactic halo, which is marked with large stars, while his crown is composed of tablets alluding to ancient knowledge and time. In his depictions of the male planets (Apollo, Mars, Jupiter, and Saturn), Burne-Jones portrayed a range of ages, from the young beardless man Apollo to the old and aged Saturn with a massive wind-blown beard. In his depictions of the female

\footnotetext{
108 See Valerie Shrimplin, Sun-symbolism and Cosmology in Michelangelo's Last Judgment (Kirksville, MO: Truman State University Press, 2000); and Valerie Shrimplin, Michelangelo, Copernicus and the Sistine Ceiling: The Last Judgment Decoded (Saarbrucken: Lambert, 2013).
} 
planets, he used as the distinction among them their quality of venustas or brightness, as seen from early morning light (Morning Star) to the scintillating light (Venus). The male planets personify authority, fortitude, and wisdom, while the female planets personify hope, justice, and love. Burne-Jones's planets impart celestial and terrestrial benevolence and protection as an orchestrated sphere. These astral rulers are seated on allegorical celestial thrones of clouds surrounded by attributes that combine their magical powers. These attributes are part of the constellations, an ancient construction for understanding the movement of the spheres and the stars as well as controlling the destiny of terrestrial beings, thus providing wonderment about the firmament. ${ }^{109}$

Burne-Jones also colored his cartoons according to the coloration of their planetary attributes, a celestial rainbow, for example: blue for the Moon; red tones for Mars; and pale yellow for Venus. He composed for each image in the cartoons a scroll with a large Latin inscription to provide two conceits: one is visual, by including in the inscription wording associated with the planetary coloration; and the other assists in comprehending the planet's role in the firmament. For example, the inscription Saturn Pallidum Sidus refers to Saturn's color: a silvery white star like a silver jubilee of longevity. The inscription accompanying Sun (Apollo), Solis Aureu Idus, decrees that the Golden Age is here, a beacon for hope. Venus's Stella Candida Venere refers to Venus as a brilliant star and astral beauty. Regia Stella Jovis proclaims Jupiter to be the Regal Star, meaning the ruler of the universe. Terra Omniparens alludes to Mother Earth or the planet Earth, where all terrestrial forms are created. ${ }^{110}$ Stella Matutina alludes to the splendorous light at early morning in contrast with Stella Vespertina, which refers to the luminous evening star. Mars Terreus signifies "the soil of Mars" alluding to Mars's chemical formation of mercurial substances projecting reddish tonalities; and Luna's Stella Mutabilis Lunae refers to the changeable movements of the moon and the oscillation of physical and metaphysical realms.

Burne-Jones's poetical inscriptions and visualizations refer to a paragone [comparison] among the sister arts or fine arts as noted by the classical poet Horace: ut pictura poesis [as is painting, so is poetry]. ${ }^{111}$ In this type of poetical combination, the text assists the viewer in interpreting the image, and the image in turn poetically makes manifest the inscription, a union between the sister arts. With the personifications of the planets and constellations, Burne-Jones created, in his Planets cycle, a stellar tapestry as a spatial background for the cosmic dwelling of the planets, hence providing a heavenly realm for terrestrial beings to contemplate and marvel about the beauty of the cosmos.

\footnotetext{
109 The interrelated astral associations and influences of the astral planets on human behaviors and types of temperaments are not addressed in this essay. See Zuffi and Novellone, Arte e Zodiaco, passim, for this type of analysis.

${ }^{110}$ See Chilb, "On the Decorations of Pianos," 167, for a description of Edward Burne-Jones's decoration of a pianoforte for William Graham in which he employed the term Earth as Terra omniparens: "[She] is the universal mother." See also Cheney, Edward Burne-Jones: Mythical Paintings, 107-113

111 The phrase originates from Horace's Arts poetica (line 361), first century BCE; for further study, see Horace on Poetry: The Ars Poetica, ed. C. O. Brink (Cambridge: Cambridge University Press, 1971). See Jean H. Hagstrum, Sister Arts: The Tradition of Literary Pictorialism and the English Poetry from Dryden to Gray (Chicago: University of Chicago Press, 1958), 59; and Michael J. B. Allen, Marsilio Ficino and the Phaedran Charioteer (Los Angeles: University of California Press, 1981), 339-439. On the history of the dispute about ut pictura poesis; see Mario Praz, Mnemosyne The Parallel Between Literature and the Visual Arts (Princeton: Princeton University Press, 1967), 2-28; John R. Spencer (1957), "Ut Rhetorica Pictura: A Study in Quattrocento Theory of Painting," Journal of the Warburg and Courtauld Institutes 20 (1957): 26-44; and Rensselaer Lee, Ut Pictura Poesis: Humanist Theory of Painting (New York: Norton, 1967), 1, n. 2. The scholarship on this topic is extensive; I am only citing some sources.
} 
Like Burne-Jones, Christina Rossetti (1830-1894), a Pre-Raphaelite poet and the sister of the Pre-Raphaelite painter and poet Dante Gabriel Rossetti (1828-1882), ${ }^{112}$ who was one of Burne-Jones's teachers, also followed Horace's poetical dictum "as is painting, so is poetry." She composed a sonnet in honor of the moon, verbalizing her feelings upon perceiving the moon and noticing the moon's pale colorations and oscillations. Her poem Is the Moon Tired? She Looks so Pale was published in the collection Sing-Song: A Nursery Rhyme Book in 1868-1870. ${ }^{113}$

Burne-Jones's first paragone is between the pen/word and the brush/image inspired by British poetical compositions on the coloration and status of the Moon. For example, Rossetti's paragone was between seeing what the Moon appears to be and employing words to express the nature of her coloration. Burne-Jones, in contrast, captured visually with a brush or a pencil on paper the object seen - the Moon (Luna) — with blush tonalities and starry luminosity, as depicted in Luna of the Planets cycle, and also noted her planetary aspects by using the Latin inscription Stella Mutabilis Lunae.

Burne-Jones's second paragone is between music and art (painting); the note and line; the sound and the brush stroke. Metaphorically, he composed a painted symphony with the Planets cycle where tones and sounds created by the movements of the planets are visualized in painted colors and harmonic designs. A modification of Horace's dictum ut pictura poesis to ut pictura musica (as is painting, so is music) relates as well to the sister arts. The Holden commission was for the purpose of decorating the Music Room with the image of the planets. The traditional concept of musica universalis or Music of the Spheres (Harmony of the Spheres) is an ancient philosophical association related to the movement of the celestial bodies. The movement of these celestial bodies - the sun, moon, and the planets - is revealed metaphysically, through mathematical constructions in order to create harmony and spiritual uplift, and physically, through sounds played with musical instruments. As Plato noted, "As the eyes, said I, seem formed for studying astronomy, so do the ears seem formed for harmonious motions: and these seem to be twin sciences to one another, as also the Pythagoreans say" (Republic VII.XII). ${ }^{114}$ Pythagoras, who invented the theory of music and sounds, claimed that the sun, moon, and planets all emit their celestial sound or orbital resonance based on their orbital revolutions. ${ }^{15}$ The traditional association of music with astronomy continued in the eighteenth century. The British astronomer William Herschel, for example, not only discovered the planet Uranus but also composed and orchestrated music. In the late nineteenth century, Burne-Jones as well combined his artistic talent as a painter in composing the Planets cycle - a stellar tapestry and a painted symphony — and as a musician following his musical inclination; he played the piano and also constructed and decorated musical

\footnotetext{
112 See GBJ Memorials, 1:133, 136, 145, 149.

113 See note 88 for the poem. An original copy, Ashley MS 1371, is at the British Museum Library in London. George Routledge and Sons were the first publishers in 1872. For this edition, Arthur Hughes (1832-1915) and Dalziel Brothers illustrated the text. In 1893, Macmillan and Co. of London reprinted the book.

114 See Henry Davis, The Republic: The Statesman of Plato (London: Dunne, 1901; repr. Nabu Press, 2012), 252; and James, The Music of the Spheres, 41-59.

115 See Stirling, The Canon, 264-274, 260, for an explanation of Pythagoras's claim that "the planets in their revolutions around the earth uttered certain sounds differing accounting to their respective magnitude, celebrity and local distance, establishing his harmony canon. See also Pliny the Elder, Natural History, Book I and II; II.xviii.xx, trans. H. Rackham (Cambridge, MA: Harvard University Press, 1938), 277-278. See also the Renaissance engraving connecting Apollo with the Muses and the planetary spheres, e.g., the planet Luna with the muse Clio: Franchinus Gafurius, Practica musicae (Milan: Gulielmum signer Rothomagensem, 1496; and Venice: Agostino Zani, 1512). And see Pliny the Elder, Natural History, Book I and II; II.xviii.xx. The translation of this ancient volume by Philemon Holland (London: Adam Firm, 1601) had a special significance for Burne-Jones. During their marriage, his wife read it aloud to him. See GBJ Memorials, 2:55; and James, The Music of the Spheres, $20-40$.
} 
instruments. ${ }^{116}$ Thus the Music Room of Woodlands was a celestial heaven where guests visiting and participating in Holden's hospitality visually enjoyed Burne-Jones's imagery while music was performed, and in a suspended moment, a pregnant moment, ${ }^{117}$ they were all transported through the music of the spheres in the heavens.

\section{References}

Allen, M. J. (1981). Marsilio Ficino and the Phaedran Charioteer. Los Angeles: University of California Press.

Allen, M. J. (1984). The Platonism of Marsilio Ficino. Los Angeles: University of California Press.

Allen, R. H. (1899). Star names and their meanings. Glastonbury, UK: The Lost Library.

Anderson, J. A. (1982). Domitian, the argiletum and the temple of peace. American Journal of Archeology, 86(1) (January), 101-110.

Archives at the Torrey Abbey Museum, Torquay, UK.

Armstrong, L. (2003). Benedetto Bordon, Aldus Manutius and Lucantonio Giunta: Old and New Links. In L. Armstrong (Ed.), Studies of renaissance miniaturists in Venice (2 vols., 2, pp. 161-183). London: Pindar.

Bell, M. (1809-1918). Sir Edward Burne-Jones. In R. Edmund Graves (Ed.), A biographical dictionary of painters and engravers (2 vols., 1, pp. 217-219). London: George Bell and Sons.

Bell, M. (1892). Edward Burne-Jones: A record and review. London: George Bell \& Sons.

Blunt, A. (1968). Artistic theory in Italy, 1450-1600. Oxford: Oxford University Press.

Brink, C. O. (Ed.). (1971). Horace on poetry: The Ars Poetica. Cambridge: Cambridge University Press.

Burne-Jones, G. (1904). Memorials of Edward Burne-Jones (2 vols.). London: Macmillan Company.

Cassirer, E. (1963/2010). The individual and the cosmos in renaissance philosophy. Chicago: University of Chicago Press.

Cecil, D. (1969). Visionary and Dreamer: Two Poetic Painters, Samuel Palmer and Edward Burne-Jones. Princeton: Princeton University Press.

Cheney, L. D. (Spring/Summer 2017). Edward Burne-Jones's The Planets: Luna, a Celestial Sphere. Culture and Cosmos: Journal for the History of Astrology and Cultural Astronomy, 21.

Cheney, L. D. (2017). Giorgio Vasari's Fine Arts from the Vite of 1550. Journal of Literature and Art Studies, 7, $140-178$.

Cheney, L. D. (2016). Edward Burne-Jones's The Planets: The Cartoon of Mars at the Birmingham Museum and Art Gallery. The Pre-Raphaelite Society, 25, 15-26.

Cheney, L. D. (2013). Edward Burne-Jones's: Mythical paintings. London/NewYork: Peter Lang.

Cheney, L. D. (2000). Edward Burne-Jones's Cupid and Psyche: The enchantment of an ancient tale. In G. Huber-Rebenich and L. Fredman (Eds.), Wegezum Mythos (pp. 57-71). Berlin: University of Mannheim.

Cheney, L. D. (1995). Burne-Jones: Mannerist in an age of modernism. In S. Casteras and A. Faxon (Eds.), Pre-raphaelite art in its European context (pp. 103-116). New Haven: Associated University Press.

Cheney, L. (1993). Botticelli’s Neoplatonic images. Potomac, MD: Scripta Humanistica.

Chevalier, J., \& Gheerbrant, A. (1994). A dictionary of symbols. London: Blackwell.

Chilb, T. (1883). On the decorations of Pianos. Early Journal Content, (1883), 167-170.

Cobb-Stevens, V. (1994). Speech, gesture and woman's hair in the Gospel of Luke and First Corinthians. In L. De Girolami Cheney (Ed.), The symbolism of vanitas in the arts, literature, and music: Comparative and historical studies (pp. 311-340). New York/Ontario: Mellen.

\footnotetext{
116 See Christopher Wood, Burne-Jones: The Life and Works of Sir Edward Burne-Jones, 1833-1898 (New York: Stewart, Tabori and Chang, 1998), 78, for records that document the early design on this subject, Le Chant d'Amour, created for a decoration of a small upright piano made by F. Priestley of Berners Street in London (now in the Victoria and Albert Museum, London). The American walnut piano was given as a wedding present to Burne-Jones in 1860. Burne-Jones painted the lid of the piano in monochrome in 1863. For Francis Homer, daughter of William Graham, an important collector and patron of Burne-Jones, he painted a piano in 1879, with themes on Orpheus, during the same time that he was designing the Planets cycle. See also Aymer Vallance, Sir Edward Burne-Jones Baronet (London: The Art Journal, 1900), 28, Figs. 54 and 55, for Burne-Jones's constructed psaltery and harp, respectively; and Cheney, Edward Burne-Jones' Mythical Paintings, 107-113.

${ }^{117}$ I am using Gotthold Ephraim Lessing's (1729-1781) term in describing the Hellenistic sculpture of Athenodoros, Polydorus and Agesander's Laocoön and His Sons, a marble copy of which is today in the Vatican Museums, Italy. See Ernest H. Gombrich, "Moment and Movement in Art," Journal of the Warburg and Courtauld Institutes 27 (1964): 293-306.
} 
Cornford, F, M. (1937 and 1997). Plato’s cosmology. London: Routledge \& Kegan Paul, repr. Indianapolis In and Cambridge MA: Hackett Publishing Co.

Cooper, J. C. (1978). An illustrated encyclopaedia of traditional symbols. London: Thames and Hudson.

Cresswell, J. (2013). Legendary beasts of Britain. Oxford: Shire Library.

Cruz, E. A. (2011). Hypnerotomachia Poliphili: An architectural vision (2 vols.). USA: Xlibris.

Davis, H. (1901/2012). The Republic: The statesman of Plato. London: Dunne and Nabu Press.

Ficino, M. (1561). Opera Omnia. Basel: Janus Cornarius.

Fitzgerald, P. (1975). Edward Burne-Jones. London: Hamilton.

Foster, B. O. trans. (1919). Titus Livius (Livy). History of Rome (2 vols.). Cambridge, MA: Harvard University Press; Loeb Classical Library.

Gafurius, F. (1512). Practica musicae. Venice: AgostinoZani.

Gafurius, F. (1496). Practica musicae. Milan: Gulielmum Signer Rothomagensem.

Garnett, O. (2000). The letters and collection of William Graham: Pre-Raphaelite patron and pre-Raphael collector. The Volume of the Walpole Society, 62, 145-343.

Gaunt, W. (1942). The Pre-Raphaelite tragedy. New York: Harcourt, Brace and Company.

Gleadow, R. (2001). The origin of the zodiac. New York: Dover.

Godwin, J. (1990). Harmony of the spheres: A sourcebook on the pythagorean tradition in music. Rochester, VT: Inner Traditions International.

Godwin, J. (2002). The pagan dream of the renaissance. Grand Rapids, MI: Phanes.

Gombrich, E. H. (1964). Moment and movement in art. Journal of the WJournal of the Warburg and Courtauld Institutes, 27, 293-306.

Grafton, A. (2000). Leon Battista Alberti: Master builder of the Italian renaissance. Cambridge, MA: Harvard University Press.

Hadingham, E. (1985). Early man and the cosmos. Norman: University of Oklahoma Press.

Hagstrum, J. H. (1958). Sister Arts: The tradition of literary pictorialism and the English poetry from Dryden to Gray. Chicago: University of Chicago Press.

Hanser, D. (Ed.). (1984). Firmitas, Utilitas, Venustas: Architecture and society. Dubuque, IA: Kendal Hunt.

Harrisons, M., \& Waters, B. (1973). Burne-Jones. New York: Putnam's Sons.

Healey, E. (1885). Woodlands of Bradford. Bradford Illustrated Weekly, 53-55.

Hevelius J. (1690). Uranographia totum caelum stellatun. Gdansk: np.

Holmes, R. (2008). The age of wonder. New York: Vintage Books.

Hyginus. (1482). Poeticon Astronomicon. Venice: Enhard Ratdolt.

James, J. (1993). The music of the spheres: Music, science and the natural order of the universe. New York: Copernicus.

Korb, E., Christian, J., \& Sidey, T. (2007). Hidden Burne-Jones, works on paper by Edward Burne-Jones from Birmingham Museums and Art Gallery. London: Dan Giles.

Lachièze-Rey, M., \& Jean-Pierre, L. (1988). Figures du Ciel: de l'armonie des spheres à la conquêtespatiale. Seuil: Bibliothèque nationale de France.

Leighton, J. A. (1922). Man and the cosmos: An introduction to metaphysics. London: Appleton.

Magee, J. (Ed. and Trans.). (2016). On Plato's Timaeus-Calcidius. Cambridge, MA: Harvard University Press.

Maxwell-Steward, P. G. (2010). Astrology: From ancient Babylon to the present. Stroud, UK: Amberley.

Morgan, M. H. (Ed.). (1960). Vitruvius, the ten books on architecture. New York: Dover.

Most, G. W. (Ed.). (2007). Hesiod, Theogony. Cambridge, MA: Harvard University Press, Loeb Classical Library.

Mulryan, M. (2012). Vincenzo Cartari, images of the gods of the ancients: The first Italian mythographer. Tempe, AZ: ACMRS.

Ono, A. (2003). Japonisme in Britain: Whistler, Menpes, Henry, Hornel and nineteenth-century Japan. London: Routledge Curzon. Oskar Kristeller, P. O. (Ed.). (1985). The letters of Marsilio Ficino (3 vols.). New York: Ginko.

Pearce, Susan. (Ed.). (2007). Visions of antiquity: The society of antiquaries of London 1707-2007. London: Society of Antiquaries. Praz, M. (1967). Mnemosyne the parallel between literature and the visual arts. Princeton: Princeton University Press.

Rackham, H. trans. (1938). Pliny the Elder. Natural History, Book I and II. Cambridge, MA: Harvard University Press.

Rensselaer Lee, R. (1967). Ut Pictura Poesis: Humanist theory of painting. New York: Norton.

Rhodes, M. (2015). Devon's Torre Abbey: Faith, politics and grand designs. New York: The History Press.

Rhodes, M. (1997). Unpublished essay on "Earth by Sir Edward Coley Burne-Jones." (dated 17 November 1997).

Robin Spencer, R. (1972). The Aesthetic movement: Theory and practice. London: Studio Vista. 
Sale, W. (19661). Aphrodite in the theogony. Transactions and Proceedings of the American Philological Association, 92, 508-521.

Samuel-Lasner, M. (1978). Note on Burne-Jones’ Hypnerotomachia Poliphili. Pre-Raphaelite Review, 1, 110.

Sentinus, J., \& Santritter, J. L. (Eds.). (1482/3). Hyginus' Poeticon Astronomicon with the illustrations of the constellations and planets. Venice: Erhard Ratdolt.

Sesti, G. M. (1991). The glorious constellations: History and mythology. New York: Harry N. Abrams.

Sewter, A. C. Notes on Morris \& Co.’s Domestic Stained Glass. Retrieved from www.morrissociety.org/JWMS/01.1-Winter1961/W61.Sewter.pdf

Sewter, A. C. (1974-75). The stained glass of William Morris and his circle. New Haven: Yale University Press.

Seznec, J. (1953). Le manuels mythologiques et leur diffusion en Angleterre à la fin de la Renaissance. Mélanges d'histoire d'archéologie, 50, 276-292.

Seznec, J. (1953). The survival of the Pagan Gods. trans. Barbara F. Sessions. New York: Harper and Row.

Shrimplin, V. (2000). Sun-symbolism and cosmology in Michelangelo’s Last Judgment. Kirksville, MO: Truman State University Press.

Shrimplin, V. (2013). Michelangelo, Copernicus and the Sistine Ceiling: The Last Judgment decoded. Saarbrucken: Lambert.

Spencer, J. R. (1957). Ut Rhetorica Pictura: A study in quattrocento theory of painting. Journal of the Warburg and Courtauld Institutes, 20, 26-44.

Stirling, W. (1897). The Canon: The pagan mystery as the rule of all the arts. Glastonbury, UK: The Lost Library.

Vallance, A. (1900). Sir Edward Burne-Jones Baronet. London: The Art Journal.

Wallis, W., \& Chamberlain, A. B. (1904). Illustrated catalogue with descriptive notes of the permanent collection of paintings and sculpture, and the pictures in Aston Hall. Birmingham: Hudson and Son.

Whitfield, P. (2001). Astrology: A history. New York: Harry N. Abrams.

Wildman, S., \& Christian, J. (1998). Edward Burne-Jones: Victorian Artist-Dreamer. New York: Metropolitan Museum of Art.

Wildman, S. (Ed.). (2004). Waking dreams: The art of the Pre-Raphaelites from the Delaware art museum. Alexandria, VA: Arts Service International.

Wood, C. (1998). Burne-Jones: The life and works of Sir Edward Burne-Jones, 1833-1898. New York: Stewart, Tabori and Chang.

Zeyl, D. J. (Trans.). (2000). Plato: Timaeus. Indianapolis IN and Cambridge MA: Hackett Publishing Co.

Zucker, M. J. (1980). The illustrated Bartsch, early Italian masters (Vol. 24). New York: Abaris, Commentary on Baccio Baldini. Zuffi, S., \& Novellone, A. (2009). Arte e Zodiaco: Storia, misteri e intepretazioni dei segnizodiacaleneisecoli. Rome: Sassi. 